\title{
4. SITE $717^{1}$
}

Shipboard Scientific Party ${ }^{2}$

HOLE 717A

Date occupied: 10 July 1987

Date departed: 10 July 1987

Time on hole: $3.75 \mathrm{hr}$

Position: $0^{\circ} 55.785^{\prime} \mathrm{S}, 81^{\circ} 23.408^{\prime} \mathrm{E}$

Water depth (sea level; $\mathbf{m}$, bottom felt): $\mathbf{4 7 3 4 . 7}$

Penetration (m): 9.5

Number of cores: 1

Total length of cored section (m): 9.5

Total core recovered $(\mathrm{m}): 9.64$

Core recovery (\%): 101

Deepest sedimentary unit cored:

Depth sub-bottom (m): 5.5

Nature: micaceous silts and calcareous clays

Age: Quaternary

Measured vertical sound velocity $(\mathrm{km} / \mathrm{s}): 1.55$

\section{HOLE 717B}

Date occupied: 10 July 1987

Date departed: 10 July 1987

Time on hole: $2.75 \mathrm{hr}$

Position: $0^{\circ} 55.785^{\prime} \mathrm{S}, 81^{\circ} 23.408^{\prime} \mathrm{E}$

Water depth (sea level, $\mathrm{m}$, bottom felt): 4734.7

Penetration (m): 13.5

Number of cores: 2

Total length of cored section (m): 13.5

Total core recovered $(\mathrm{m}): 13.43$

Core recovery $(\%)$ : 99.6

Deepest sedimentary unit cored:

Depth sub-bottom (m): 5.5

Nature: micaceous silts and calcareous clays

Age: late Quaternary

Measured vertical sound velocity $(\mathrm{km} / \mathrm{s}): 1.55$

\section{HOLE 717C}

Date occupied: 10 July 1987

Date departed: 19 July 1987

Time on hole: 9.6 days

Position: $0^{\circ} 55.785^{\prime} \mathrm{S}, 81^{\circ} 23.408^{\prime} \mathrm{E}$

Water depth (sea level, $\mathrm{m}$, bottom felt): 4734.7

Penetration (m): 828.2

\footnotetext{
${ }^{1}$ Cochran, J. R., Stow, D.A.V., et al., 1988. Proc. ODP, Init. Repts., 116: College Station, TX (Ocean Drilling Program).

${ }^{2}$ Shipboard Scientific Party is as given in the list of Participants preceding the contents.
}

Number of cores: 91

Total length of cored section (m): 814.8

Total core recovered $(\mathrm{m}): 480.2$

Core recovery $(\%): 58.9$

Deepest sedimentary unit cored:

Depth sub-bottom (m): 533.2

Nature: silt and silt mud turbidites

Age: late Miocene

Measured vertical sound velocity $(\mathrm{km} / \mathrm{s}): 1.7$ to 2.0

\section{SITE 717 SUMMARY}

Principal Results: The stratigraphic section recovered at Site 717 ranges from late Quaternary to the base of the late Miocene and has been divided into five main lithologic units. The dominant lithologies and ages of the stratigraphic sequence are as follows:

Unit I (0-5.5 mbsf): Muds, mud turbidites and pelagites of $\mathrm{Hol}-$ ocene to latest Pleistocene age.

Unit II (5.5-152.0 mbsf): Micaceous silty turbidites with thin intervening muds and calcareous clays of late Pleistocene age.

Unit III (152.0-303.2 mbsf): Biogenic mud turbidites and mud turbidites with thin interbedded pelagic clays of Pleistocene and late Pliocene age.

Unit IVA (303.2-340.8 mbsf): Silt turbidites with thin muds and mud turbidites of late Pliocene age.

Unit IVB (340.8-456.0 mbsf): Mud turbidites with interbedded pelagic clays of late Pliocene to late Miocene age.

Unit IVC (456.0-465.2 mbsf): Silt and silt to mud turbidites with minor amounts of mud of late Miocene age.

Unit IVD (465.2-533.2 mbsf): Mud turbidites with interbedded pelagic clays of late Miocene age.

Unit V (533.2-828.2 mbsf): Silt and silt to mud turbidites with rare intervals of pelagic clay and organic rich mud turbidites of upper Miocene age.

Sedimentation at Site 717 is dominated by fan sedimentation processes and consists mainly of a sequence of turbidites. A thin layer of mud $(5.5 \mathrm{~m})$ overlies a sequence dominated by micaceous silt turbidites which accumulated very rapidly during the late Pleistocene at a rate probably in excess of $350 \mathrm{~m} / \mathrm{m}$.y. This unit comprises a distinctive seismic stratigraphic unit which in places truncates lower reflectors. These coarser grained, rapidly deposited turbidites may reflect the Pleistocene sea-level lowstand. Units III and IV together represent a thick section of mainly mud turbidites with thin interbedded pelagic clays that accumulated at a slower average rate of about $70 \mathrm{~m} / \mathrm{m} . \mathrm{y}$. through the latest Miocene and upper Pliocene. Distinctive green, biogenic turbidites characterize Unit III and at least two pulses of coarser silty turbidites occur in Unit IV. The lowest unit consists of a monotonous sequence of micaceous silt and silt-mud turbidites separated by intervals of muds and pelagic clays. The average accumulation rate for the whole of this unit is $90-100$ $\mathrm{m} / \mathrm{m} . \mathrm{y}$.

The sequence of lithostratigraphic units at Site 717 gives a very good record of sedimentation on the distal fan showing the nature, thickness, and vertical succession of turbidites that have been transported over $2500 \mathrm{~km}$. At least three different sources of turbidites can be tentatively identified: silts and muds from the Ganges-Brahmaputra delta, dark-gray organic rich muds from the upper slope of the Bay of Bengal, and greenish biogenic turbidites probably from the Afanasy-Nitikin Seamount group. One of the main controls on sedimentation appears to have been sea-level variation. A second important factor $\mathrm{w}$ as probably changes in rates of erosion related to Himalayan uplift history. Local tectonic effects, perhaps related to 
the intraplate deformation, may have resulted in the more local supply of biogenic turbidites from adjacent seamounts.

The biostratigraphic control at Site 717 is based primarily on nannofossils. The site has clearly been close to or below the carbonate compensation depth for at least the past 10 m.y. Siliceous microfossils are almost completely absent in spite of the location of the site within the supposed equatorial high-productivity zone.

Site 717 successfully established a reference section for comparison with other sites higher up the fault blocks. There is some evidence, from physical property measurements, of horizontal stress but the heat flow is normal for 78-Ma crust and a complete sedimentary sequence was recovered with no marked unconformities. The seismic unconformity that appears to mark the onset of intraplate deformation occurs within Unit $\mathrm{V}$ and does not correspond to a change of lithology. Interpolation between well established paleontological dates gives an age of $7.5 \mathrm{Ma}$ for the beginning of the deformation.

\section{BACKGROUND AND OBJECTIVES}

\section{Background}

Site 717 is one of three closely-spaced sites located near $1^{\circ} \mathrm{S}$, $81^{\circ} 24^{\prime} \mathrm{E}$ in the central Indian Ocean approximately $800 \mathrm{~km}$ south of Sri Lanka and $200 \mathrm{~km}$ northwest of the Afanasy Nitikin Seamount group (Fig. 1). It lies at the distal end of the Bengal Fan within a large area of intraplate deformation that affects both the ocean crust and the thick pile of overlying sediments.

Both deposition and deformation in this part of the central Indian Ocean have been affected by the collision between the Indian and Asian plates. This plate interaction began in the Eocene at anomaly 22 time (approximately $53 \mathrm{Ma}$ ago) with a soft collision, possibly between continental India and an island arc lying seaward of Asia. This collision led to a halving of the spreading rate to $4 \mathrm{~cm} / \mathrm{yr}$ (Sclater and Fisher, 1974; Curray et al., 1982). A regional unconformity observed on the proximal and mid fan areas (Curray and Moore, 1971) has been dated to this time by extrapolation from DSDP Site 218 (Moore et al., 1974).

During the Oligocene, the spreading rate decreased still further to $2.5 \mathrm{~cm} / \mathrm{yr}$, the spreading direction of the Southeast Indian Ridge changed from N-S to NE-SW (Sclater et al., 1976), and sedimentation in the area now covered by the Bengal Fan probably increased. The hard continent-continent collision may have occurred at that time, although other estimates are as late as late Miocene (Powell and Conaghan, 1973). A second prominent regional unconformity in the area of the Bengal Fan has also been dated as late Miocene by drilling at DSDP Site 218 (Thompson, 1974). The unconformity marking the onset of deformation in the distal fan is inferred by extrapolation to be this same event (Weissel et al., 1980).

Rapid terrigenous sedimentation on an incipient Bengal Fan began in the Eocene as a response to the first interplate collision (Curray and Moore, 1971), and has continued to the present day, constructing the world's largest submarine fan-over 2500 $\mathrm{km}$ long and over $12 \mathrm{~km}$ thick-under the northern Bay of Bengal. In the area of Site 717 , the sediment is approximately $1.5-2 \mathrm{~km}(2 \mathrm{~s})$ thick under the very distal part of the fan. This enormous volume of sediments is assumed to have been derived principally from denudation of the uplifting Himalayan Mountains and then supplied to the delta front via the GangesBrahmaputra river system.

Sediments are funneled very efficiently to the fan via a deltafront trough, the "Swatch of No Ground." This trough is presently connected to only one active fan channel, but has been effectively cut off from rapid sediment supply since the most recent rise in sea level, probably about 7,000-10,000 yr ago. The fan channel appears to terminate some $50-100 \mathrm{~km}$ north of Site
717 , and no channel or levee-type features have been observed on seismic reflection records in the Leg 116 study area.

The increased resistance to subduction and to shortening across the Himalayas since the continent-continent collision, combined with continued spreading on the southeast Indian Ridge, has placed the central Indian Ocean under a large northsouth compressive stress regime (Stein and Okal, 1978). As a result, the ocean crust and most of the overlying sediments have been deformed into long-wavelength (100-300 km) undulations with peak-to-trough amplitudes of $1-3 \mathrm{~km}$ over a large area, which extends roughly from the the Chagos-Laccadive Ridge in the west to the Ninetyeast Ridge and from $5^{\circ} \mathrm{N}$ to $10^{\circ} \mathrm{S}$ latitude (Weissel et al., 1980; Geller et al., 1983).

Superimposed on the long-wavelength undulations are faulted and rotated blocks, $5-20 \mathrm{~km}$ wide, interpreted as showing a reverse sense of displacement on the faults separating them (Geller et al., 1983), which is consistent with north-south shortening. The top of the ocean crust is seen to be offset across these faults by up to $0.5 \mathrm{~s}(>500 \mathrm{~m})$ on seismic reflection records (Fig. 2). The lower portion of the sedimentary sequence is deformed along with the basement. A prominent unconformity separates the predeformation sequence from an upper syndeformation sequence, which thins towards the tops of blocks and shows pinching out of individual beds.

\section{Objectives}

Site 717 is located in $4730 \mathrm{~m}$ water depth within the thickest sedimentary section between adjacent fault-block highs (Fig. 2). On the seismic reflection records, the unconformity noted higher up the tilted block becomes conformable in the thicker section, which appears to show continuous sedimentation without marked discontinuities or deformation. The principal objectives of the Site were:

1. To establish a reference hole in the area, for comparison with the other sites where the section is less complete, and to calibrate the regional seismic stratigraphy to a depth of about $800 \mathrm{~m}$;

2. To measure the physical and hydrological properties in an undisturbed area;

3. To characterize the main lithofacies and determine the depositional processes responsible;

4. To establish the provenance of sediments on the distal fan and to assess to what extent compositional variations reflect the uplift history of the Himalayas; and

5. To characterize the nature of early diagenesis in the reference section of fan sediments.

\section{OPERATIONS}

JOIDES Resolution sailed from the port of Colombo, Sri Lanka, at $1715 \mathrm{hr}$ local time, 7 July 1987, to begin Leg 116 . The magnetometer was deployed after crossing the Sri Lanka continental shelf and the ship proceeded directly to Site 717. A distance of $882 \mathrm{~km}(476 \mathrm{nmi})$ was covered in $36.5 \mathrm{hr}$ at $13.04 \mathrm{kt}$. At $0545 \mathrm{hr}, 9$ July 1987 , the ship slowed to deploy the seismic gear and began a site survey. A seismic line was run from north to south $6 \mathrm{~km}$ to the east of the site and a parallel line was run back to the north over the proposed locations of all three Leg 116 sites. The beacon was dropped at $1115 \mathrm{hr}, 9$ July 1987, at $00^{\circ} 55.785^{\prime} \mathrm{S}, 81^{\circ} 23.408^{\prime} \mathrm{E}$. By $1230 \mathrm{hr}$ the ship was on location and began setting pipe.

The first APC core from Hole 717A was brought on deck at 0305, 10 July 1987 . A full 9.64 -m core was recovered, indicating that the bit had been below the mud line. The ship was moved and Hole 717B spudded in at $0345 \mathrm{hr}$. The first two APC cores penetrated $13.5 \mathrm{~m}$, recovering $13.43 \mathrm{~m}$ of sediment. However, 


\section{A}

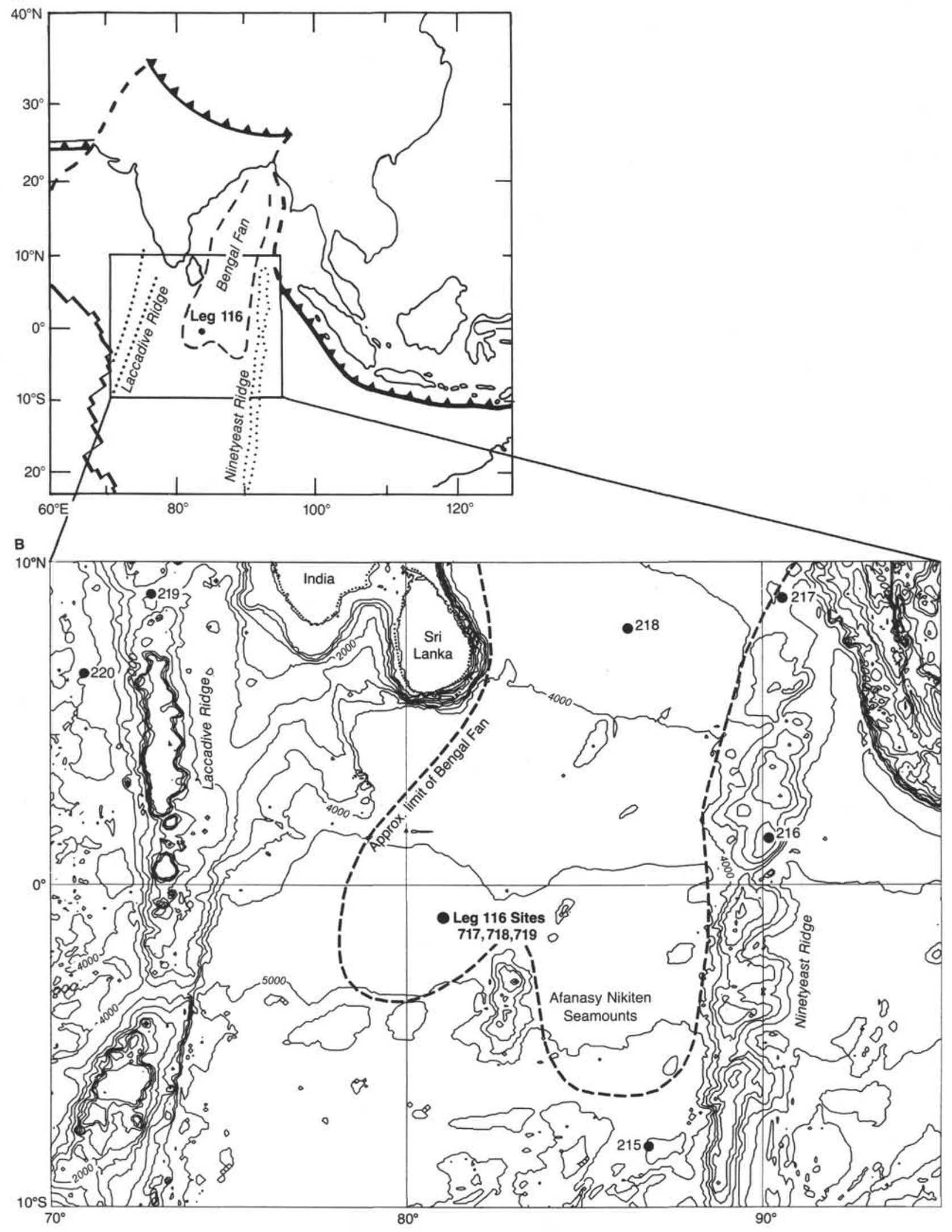

Figure 1. Location maps for the Leg 116 sites. A. Setting of Leg 116 sites relative to tectonic elements of the eastern Indian Ocean. Heavy solid line represents mid-ocean ridge axes, dashed lines are transform plate boundaries and saw-tooth pattern shows convergent plate boundaries. B. Setting of Leg 116 sites within the north central Indian Ocean. Bathymetry is machine-contoured DBDB10 gridded data set at 500$\mathrm{m}$ intervals. Location of other DSDP drill sites within the region is also shown. 
$\mathrm{N}$

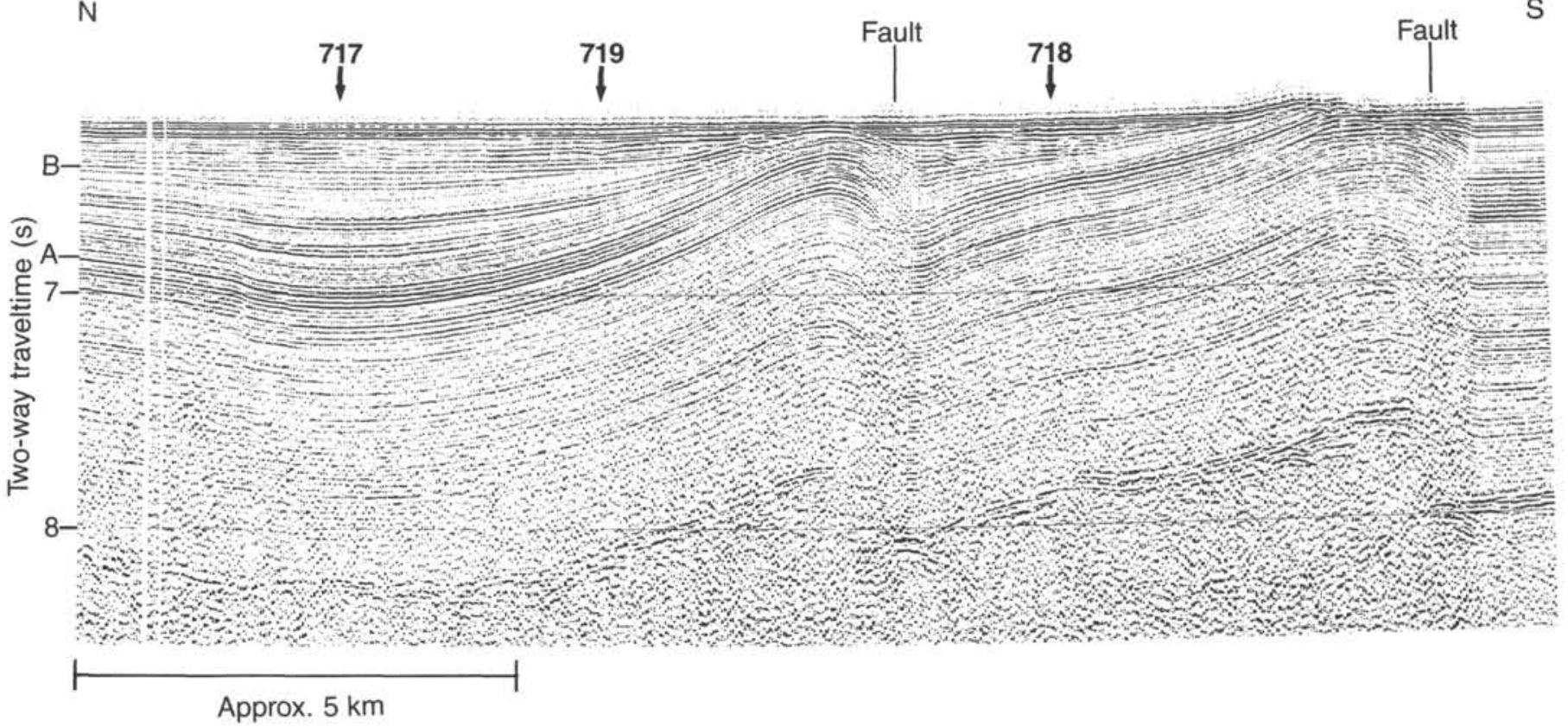

Figure 2. North-South seismic reflection profile across the Leg 116 drill sites. Locations of Sites 717, 718, and 719 are shown. Also noted are the locations of the faults bounding the tilted blocks and prominent unconformities " $\mathrm{A}$ " and " $\mathrm{B}$ ".

on the third APC core, the core barrel was snapped with the loss of an APC heat flow shoe.

The ship was moved forward $10 \mathrm{~m}$ and Hole $717 \mathrm{C}$ spudded

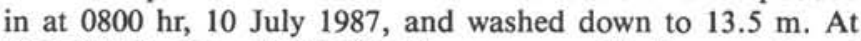
Hole $717 \mathrm{C}$, Core 116-717C-3H came up with the core barrel bent. It was concluded that the bottom consists of a layer of soft clay on top of hard fine sand that could not be penetrated by the APC system. Therefore, at 17.5 mbsf APC coring was terminated and the $\mathrm{XCB}$ deployed. Continuous coring with the $\mathrm{XCB}$ continued to a depth of $828.2 \mathrm{mbsf}$, setting a record for $\mathrm{XCB}$ penetration. The last core was brought on deck at $1100 \mathrm{hr}$, 16 July 1987 . Recovery in clay and mud turbidites was generally excellent. Recovery in turbidites with quantities of silt and fine sand was generally quite poor. A total of $814.7 \mathrm{~m}$ was cored at Site $717 \mathrm{C}$ with a recovery of $480.2 \mathrm{~m}$ or $58.9 \%$. The details of the coring operation are given in Table 1 .

The hole was then conditioned, the bit released, and the drill pipe picked up to $66 \mathrm{mbsf}$ in preparation for logging. The Schlumberger logging tools were prepared and the side entry sub (SES) was installed. The tools did not function properly and it was necessary to lay them on the deck for testing and repair. After $14 \mathrm{hr}$ of work the tools and SES were finally ready for deployment. The logging tools were run down the pipe to a wireline measurement of $4735 \mathrm{~m}$, at which point they would not go any further. The sonic tool indicated that the tool string was not in the pipe.

The logging tools and SES were recovered and the drill pipe pulled. It was found that the bottom hole assembly (BHA) was missing below the bottom of the top drill collar. The logging tools had appearently gone out the bottom of the pipe and hit the seafloor. The reason for the parting of the BHA is not known. No additional logging operations were possible at Hole 717C so the ship got underway for the next site at $2116 \mathrm{hr}, 19$ July 1987.

\section{LITHOSTRATIGRAPHY}

\section{Lithofacies}

The stratigraphic sequence penetrated at Site 717 consists predominantly of interbedded clays, silty clays, and silts, with lesser amounts of sandy silts and calcareous clay, ranging in age from Quaternary to late Miocene. The sediments can be divided into seven distinct facies on the basis of texture, sedimentary and biogenic structures, color, organic carbon content, and the presence or absence of calcareous microfossils.

\section{Facies 1. Silt and Silt-Mud Turbidites. (F1)}

Facies 1 consists of sharp-based, upward-fining beds of darkgray silt, or less commonly sandy silt, which grade upward through silty clay to clay. Internally the beds may be massive or rarely show a faint horizontal lamination in the basal few centimeters (e.g., Sample 116-717B-2H-3, 60-112 cm) (Fig. 3). The beds of this facies range from 7-140 cm thick, averaging $40 \mathrm{~cm}$. Bioturbation and calcareous microfossils are rare.

\section{Facies 2. Organic-poor Mud Turbidites. (F2)}

Facies 2 consists of sharp-based, thickly to very thickly (30$220 \mathrm{~cm}$ ) bedded, light-gray to gray, silty clays which pass upward into clay. Typically silt comprises only $10 \%$ of the sediment and is concentrated in the lowermost third of the beds. The bases of beds are often marked by clean silt laminae, one grain diameter to several millimeters thick. The silt fraction consists mainly of quartz with mica (less than 10\%) and feldspar (traces). Plant debris ranges from zero to $1 \%$. Bioturbation and calcareous microfossils are largely absent.

\section{Facies 3. Organic-rich Mud Turbidites. (F3)}

Facies 3 is characterized by large amounts $(2 \%-15 \%$, avg. $5 \%$ ) of plant debris and consists of very dark-gray to black, sharp-based, upward-fining beds $50-100 \mathrm{~cm}$ thick (avg. $80 \mathrm{~cm}$ ) of silty clay. The beds generally commence with silty clay (less than $80 \%$ silt) and pass upward into clay. Typically the basal few centimeters exhibit a horizontal lamination that passes upward into a faint wispy lamination and finally into a massive interval. Pyrite (after wood, burrows, and as concretions) is ubiquitous (see below). The tops of the beds are commonly bioturbated.

\section{Facies 4. Biogenic Mud Turbidites. (F4)}

This facies consists of sharp-based, upward fining, olive-gray calcareous silty clays (with a silt content less than 10\%) and 
clay. Beds of this facies range in thickness from 10 to $290 \mathrm{~cm}$ (avg. $50 \mathrm{~cm}$ ). A thin (less than $3 \mathrm{~cm}$ ) basal silt layer may occur. Rarely, a faint horizontal lamination is present but most commonly the beds appear massive. In contrast to the other facies (with the exception of the basal silts of Facies 6) calcareous microfossils (mainly nannofossils, but with common foraminifers) are ubiquitous, making up to $20 \%$ of the sediment. In addition, unidentified calcareous silt and clay-sized material accounts for 20 to $30 \%$ of the sediment. The tops of the beds are commonly bioturbated.

\section{Facies 5. Pelagic Clays. (F5)}

This facies consists of gradationally based beds of clay 5 to $25 \mathrm{~cm}$ thick, varying in color from a mottled red-green to gray. Bioturbation and ferromanganiferous(?) chemical fronts characterize the facies. Calcareous microfossils are rare to absent; those that remain show evidence of extreme dissolution.

\section{Facies 6. Pelagic Calcareous Clays. (F6)}

Facies 6 consists of light to dark-gray bioturbated clays with approximately $5 \%$ silt. It is characterized by an abundant fauna of nannofossils (up to 50\%) and foraminifers (up to 5\%). Bioturbation is common and intense.

\section{Facies 7. Structureless Muds. (F7)}

Facies 7 consists of beds ( $2-100 \mathrm{~cm}$ thick) of dark to lightgray silty clay and clay with indistinct bed boundaries. The beds may or may not be bioturbated. Ferromanganiferous(?) chemical fronts are absent. Calcareous microfossils are largely absent but occasionally occur in trace amounts.

\section{Lithologic Units}

On the basis of the distribution of these facies the sedimentary sequence penetrated at Site 717 has been divided into five lithologic units, with Unit IV being divided into four subunits (Fig. 4).

\section{Unit I. Cores 116-717B-1H and 116-717B-2H; 0 to $5.5 \mathrm{mbsf}$}

Unit $\mathrm{I}$ is $5.5 \mathrm{~m}$ thick and is composed of interbedded structureless muds (F7), organic-poor mud turbidites (F2), and calcareous clays (F6).

\section{Unit II. Cores 116-717B-2H to $116-717 \mathrm{C}-20 \mathrm{X} ; 5.5$ to $152 \mathrm{mbsf}$}

Unit II consists of $146.5 \mathrm{~m}$ of predominantly facies 1 silt and silt-mud turbidites, with thin interbeds of structureless muds (F7) and calcareous clay (F6).

\section{Unit III. Cores 116-717C-20X to 116-717C-36X; 152 to} $303.2 \mathrm{mbsf}$

Unit III is $151.2 \mathrm{~m}$ thick and is characterized by the presence of biogenic mud turbidites (F4), which decrease in abundance with depth through the unit. Interbedded with the biogenic mud turbidites are organic-poor (F2) and organic-rich mud turbidites (F3), together with structureless muds (F7) and pelagic clays (F5). The latter tend to occur as thin caps on both turbidite facies.

\section{Unit IV. Cores 116-717C-36X to 116-717C-60X; 303.2 to} $533.3 \mathrm{mbsf}$

This unit has been subdivided into four subunits on the basis of the presence, abundance and thickness of silt and silt-mud turbidites.
Subunit IVa. Cores 116-717C-36X to 116-717C-39X; 303.2 to $340.8 \mathrm{mbsf}$

Subunit IVa is $37.6 \mathrm{~m}$ thick and is characterized by an abundance of facies 1, silt turbidites (Fig. 3), although thin structureless muds (F7) and mud turbidites of Facies 2 and 3 also occur.

Subunit IVb. Cores 116-717C-40X to 116-717C-52X; 340.8 to $456 \mathrm{mbsf}$

Subunit IVb is $115.2 \mathrm{~m}$ thick and consists of interbedded organic-rich (F3) and organic-poor (F2) mud turbidites, structureless muds (F7) and pelagic clays (F5), differing from Unit III in that the biogenic mud turbidites (F4) are absent, and that rare silt-mud turbidites (F1) occur.

\section{Subunit IVc. Cores 116-717C-52X to 116-717C-53X; 456 to $465.2 \mathrm{mbsf}$}

Subunit IVc is $9.2 \mathrm{~m}$ thick and is characterized by the abundance of silt and silt-mud turbidites (F1) with minor amounts of structureless mud (F7).

Subunit IVd. Cores 116-717C-53X to 116-717C-60X; 465.2 to $533.2 \mathrm{mbsf}$

Subunit IVd is $68 \mathrm{~m}$ thick and is broadly similar to Subunit $\mathrm{IVb}$, the only difference being the presence of rare, thin calcareous clays (F6).

Unit V. Cores 116-717C-60X to 116-717C-91X; 533.2 to $828.2 \mathrm{mbsf}$

This unit is a monotonous sequence ( $295 \mathrm{~m}$ thick) of predominantly silt and silt-mud turbidites (F1) with rare, thin intervals of pelagic calcareous clay (F6), structureless mud (F7), and organic-rich mud turbidites (F3).

\section{Maximum Quartz Grain Size}

Maximum grain size was determined at approximately $10-\mathrm{m}$ intervals at Site 717. In each case the coarsest and/or thickest lithology in the individual core (generally from the base of the coarsest turbidite) was chosen for smear-slide analysis and the largest equant quartz grain measured. Results of the analysis are shown graphically in Figure 5.

The analysis reveals that the maximum grain-size range is from 30 to $440 \mu \mathrm{m}$ (coarse silt to medium sand on the Wentworth Scale). Not surprisingly the coarsest maximum grain size corresponds to the sandy silt and silt turbidites of Facies 1 within Units II and V and Subunits IVa and IVc. However, the background values throughout the sequence show that coarse siltsized material was able to reach this most distal fan setting via turbidity currents throughout the interval from the late Miocene to the Quaternary sampled at Site 717.

\section{Carbonate Content}

Results of analysis of carbonate content at Site 717 is shown in Figure 6. The graph reveals a slight increase with depth. Superimposed on this general trend are two facies effects. First, the coarser facies show higher carbonate contents than adjacent finer lithologies (with the exception of Facies 4) reflecting either diagenetic carbonate precipitation or the presence of transported(?) biogenic carbonate. Second, the few very high values correspond to the biogenic mud turbidite facies (F4) reflecting their high biogenic calcite content.

\section{Pyrite Occurrence}

Pyrite is ubiquitous in Facies 3. It appears most commonly as tube fillings $1-2 \mathrm{~mm}$ in diameter, 5 to more than $20 \mathrm{~mm}$ long, 
Table 1. ODP Site 717 coring summary.

\begin{tabular}{|c|c|c|c|c|c|c|c|c|}
\hline Hole & $\begin{array}{c}\text { Core } \\
\text { no. }\end{array}$ & $\begin{array}{c}\text { Date } \\
\text { (July 1987) }\end{array}$ & Time & $\begin{array}{c}\text { Top } \\
\text { (mbsf) }\end{array}$ & $\begin{array}{c}\text { Bottom } \\
\text { (mbsf) }\end{array}$ & $\begin{array}{c}\text { Meters } \\
\text { cored } \\
\text { (m) }\end{array}$ & $\begin{array}{l}\text { Meters } \\
\text { recovered } \\
\text { (m) }\end{array}$ & $\begin{array}{l}\text { Percent } \\
\text { recovery }\end{array}$ \\
\hline \multirow[t]{2}{*}{ A } & IH & 10 & 0305 & 0.0 & 9.5 & 9.5 & 9.64 & 101.0 \\
\hline & & & & & & 9.5 & 9.64 & \\
\hline B & $1 \mathrm{H}$ & 10 & 0405 & 0.0 & 4.0 & 4.0 & 4.00 & 100.0 \\
\hline \multirow[t]{2}{*}{ B } & $2 \mathrm{H}$ & 10 & 0455 & 4.0 & 13.5 & 9.5 & 9.43 & 99.2 \\
\hline & & & & & & 13.5 & 13.43 & \\
\hline C & $1 \mathrm{~W}$ & 10 & 0715 & 0.0 & 13.5 & & 0.00 & 0.0 \\
\hline C & $2 \mathrm{H}$ & 10 & 0835 & 13.5 & 17.5 & 4.0 & 2.82 & 70.5 \\
\hline C & $3 \mathrm{X}$ & 10 & 1030 & 17.5 & 27.0 & 9.5 & 0.03 & 0.3 \\
\hline C & $4 X$ & 10 & 1145 & 27.0 & 36.5 & 9.5 & 0.64 & 6.7 \\
\hline C & $5 X$ & 10 & 1315 & 36.5 & 46.0 & 9.5 & 1.94 & 20.4 \\
\hline C & $6 x$ & 10 & 1445 & 46.0 & 55.5 & 9.5 & 2.35 & 24.7 \\
\hline C & $7 X$ & 10 & 1630 & 55.5 & 65.0 & 9.5 & 2.15 & 22.6 \\
\hline C & $8 X$ & 10 & 1810 & 65.0 & 74.5 & 9.5 & 2.58 & 27.1 \\
\hline C & 9I & 10 & 2045 & 74.5 & 74.5 & 0.0 & 0.00 & \\
\hline C & $10 \mathrm{X}$ & 10 & 2200 & 74.5 & 84.0 & 9.5 & 1.83 & 19.2 \\
\hline C & $11 X$ & 10 & 2330 & 84.0 & 93.5 & 9.5 & 0.08 & 0.8 \\
\hline C & $12 X$ & 11 & 0105 & 93.5 & 103.0 & 9.5 & 0.12 & 1.3 \\
\hline C & $13 \mathrm{I}$ & 11 & 0305 & 103.0 & 103.0 & 0.0 & 0.00 & \\
\hline C & $14 X$ & 11 & 0420 & 103.0 & 112.5 & 9.5 & 2.82 & 29.7 \\
\hline C & $15 \mathrm{X}$ & 11 & 0545 & 112.5 & 122.0 & 9.5 & 2.35 & 24.7 \\
\hline C & $16 X$ & 11 & 0715 & 122.0 & 131.5 & 9.5 & 1.66 & 17.5 \\
\hline C & $17 \mathrm{I}$ & 11 & 0845 & 131.5 & 131.5 & 0.0 & 0.00 & \\
\hline C & $18 \mathrm{X}$ & 11 & 1010 & 131.5 & 141.0 & 9.5 & 0.20 & 2.1 \\
\hline C & $19 X$ & 11 & 1140 & 141.0 & 150.5 & 9.5 & 1.46 & 15.3 \\
\hline C & $20 \mathrm{X}$ & 11 & 1330 & 150.5 & 160.0 & 9.5 & 5.50 & 57.9 \\
\hline C & $21 X$ & 11 & 1540 & 160.0 & 169.5 & 9.5 & 6.08 & 64.0 \\
\hline C & $22 X$ & 11 & 1725 & 169.5 & 179.0 & 9.5 & 7.10 & 74.7 \\
\hline C & $23 \mathrm{X}$ & 11 & 1920 & 179.0 & 188.5 & 9.5 & 9.70 & 102.0 \\
\hline C & $24 X$ & 11 & 2115 & 188.5 & 198.0 & 9.5 & 9.67 & 102.0 \\
\hline C & $25 \mathrm{X}$ & 11 & 2310 & 198.0 & 207.5 & 9.5 & 7.67 & 80.7 \\
\hline C & $26 \mathrm{X}$ & 12 & 0105 & 207.5 & 217.0 & 9.5 & 9.62 & 101.0 \\
\hline C & $27 X$ & 12 & 0250 & 217.0 & 226.5 & 9.5 & 9.29 & 97.8 \\
\hline C & $28 \mathrm{X}$ & 12 & 0430 & 226.5 & 236.0 & 9.5 & 8.12 & 85.5 \\
\hline C & $29 X$ & 12 & 0615 & 236.0 & 245.5 & 9.5 & 9.56 & 100.0 \\
\hline C & $30 \mathrm{X}$ & 12 & 0800 & 245.5 & 255.0 & 9.5 & 9.68 & 102.0 \\
\hline C & $31 X$ & 12 & 0945 & 255.0 & 264.5 & 9.5 & 3.90 & 41.0 \\
\hline C & $32 \mathrm{X}$ & 12 & 1115 & 264.5 & 274.0 & 9.5 & 7.66 & 80.6 \\
\hline C & $33 X$ & 12 & 1310 & 274.0 & 283.5 & 9.5 & 9.73 & 102.0 \\
\hline C & $34 X$ & 12 & 1505 & 283.5 & 293.0 & 9.5 & 5.28 & 55.6 \\
\hline C & $35 \mathrm{X}$ & 12 & 1700 & 293.0 & 302.5 & 9.5 & 9.73 & 102.0 \\
\hline C & $36 x$ & 12 & 1855 & 302.5 & 312.0 & 9.5 & 9.73 & 102.0 \\
\hline C & $37 X$ & 12 & 2035 & 312.0 & 321.5 & 9.5 & 4.14 & 43.6 \\
\hline C & $38 \mathrm{X}$ & 12 & 2215 & 321.5 & 331.0 & 9.5 & 5.71 & 60.1 \\
\hline C & $39 \mathrm{X}$ & 12 & 2345 & 331.0 & 340.5 & 9.5 & 1.64 & 17.2 \\
\hline C & $40 x$ & 13 & 0150 & 340.5 & 350.0 & 9.5 & 9.68 & 102.0 \\
\hline C & $41 X$ & 13 & 0350 & 350.0 & 359.5 & 9.5 & 0.78 & 8.2 \\
\hline C & $42 X$ & 13 & 0520 & 359.5 & 369.0 & 9.5 & 9.27 & 97.6 \\
\hline C & $43 X$ & 13 & 0830 & 369.0 & 378.5 & 9.5 & 9.80 & 103.0 \\
\hline C & $44 X$ & 13 & 1020 & 378.5 & 388.0 & 9.5 & 9.45 & 99.5 \\
\hline
\end{tabular}

often vertically oriented and abundant in sections of the core a few centimeters thick. These occurrences are interpreted as burrow fills. They are commonly associated with vertical veinlets (up to $1 \mathrm{~mm}$ in diameter) filled by an unidentified (X-ray opaque) material that may represent burrows, gas, water escape pipes, or microfractures. The other occurrences of iron sulfide are: small isolated concretions or nodules, less than $5 \mathrm{~mm}$ in size, in brown to dark-gray clays; fine lenses or layers (no more than 2-3 mm thick) of pyritic silt or sandy silt found in clays or sometimes at the bases of layers rich in plant debris; and as replacement of fossils such as plant fragments or occasionally microfossils (especially radiolarians).

\section{Geochemistry of Sediments}

Table 2 shows the data generated by X-ray fluorescence analysis, including the sum of the concentrations of the oxides (column TOTAL) and the Loss on Ignition (column LOI). Also shown are the color values assigned to the samples in the Visual Core Descriptions.

The first conclusion we draw from these data is that the ignition technique in use is not completely calcining the calcium carbonate in the carbonate-rich samples. The samples with the four highest $\mathrm{CaO}$ concentrations are also the samples whose total weight is least. LOI is also highest for these samples, but is insufficient to explain the discrepancy. Silica and alumina are highly correlated but this is mostly a function of dilution by calcium carbonate. When concentrations are recalculated to a $\mathrm{CaO}$ free basis to remove this dilution effect, silica is weakly inversely correlated with alumina, reflecting variations in the proportions of quartz and alumina-rich clay minerals in the noncarbonate fraction.

There is a moderately significant inverse relationship between $\mathrm{Fe}_{2} \mathrm{O}_{3}$ and $\mathrm{MnO}$. This probably represents the geochemical separation of iron and manganese in reducing environments, with 
Table 1 (continued).

\begin{tabular}{|c|c|c|c|c|c|c|c|c|}
\hline Hole & $\begin{array}{l}\text { Core } \\
\text { no. }\end{array}$ & $\begin{array}{c}\text { Date } \\
\text { (July 1987) }\end{array}$ & Time & $\begin{array}{c}\text { Top } \\
\text { (mbsf) }\end{array}$ & $\begin{array}{c}\text { Bottom } \\
\text { (mbsf) }\end{array}$ & $\begin{array}{c}\text { Meters } \\
\text { cored } \\
\text { (m) }\end{array}$ & $\begin{array}{l}\text { Meters } \\
\text { recovered } \\
\text { (m) }\end{array}$ & $\begin{array}{l}\text { Percent } \\
\text { recovery }\end{array}$ \\
\hline C & $45 \mathrm{X}$ & 13 & 1215 & 388.0 & 397.5 & 9.5 & 9.79 & 103.0 \\
\hline C & $46 \mathrm{X}$ & 13 & 1405 & 397.5 & 407.0 & 9.5 & 5.86 & 61.7 \\
\hline C & $47 X$ & 13 & 1615 & 407.0 & 416.5 & 9.5 & 4.76 & 50.1 \\
\hline C & $48 \mathrm{X}$ & 13 & 1805 & 416.5 & 426.0 & 9.5 & 9.72 & 102.0 \\
\hline C & $49 X$ & 13 & 1850 & 426.0 & 435.5 & 9.5 & 6.74 & 70.9 \\
\hline C & $50 \mathrm{X}$ & 13 & 2140 & 435.5 & 445.0 & 9.5 & 9.68 & 102.0 \\
\hline C & $51 X$ & 13 & 2315 & 445.0 & 454.5 & 9.5 & 6.26 & 65.9 \\
\hline C & $52 \mathrm{X}$ & 14 & 0445 & 454.5 & 464.0 & 9.5 & 4.51 & 47.5 \\
\hline C & $53 X$ & 14 & 0915 & 464.0 & 473.5 & 9.5 & 9.79 & 103.0 \\
\hline C & $54 \mathrm{X}$ & 14 & 1115 & 473.5 & 483.0 & 9.5 & 9.70 & 102.0 \\
\hline C & $55 \mathrm{X}$ & 14 & 1300 & 483.0 & 492.5 & 9.5 & 4.21 & 44.3 \\
\hline C & $56 \mathrm{X}$ & 14 & 1405 & 492.5 & 502.0 & 9.5 & 9.86 & 104.0 \\
\hline C & $57 X$ & 14 & 1610 & 502.0 & 511.5 & 9.5 & 9.73 & 102.0 \\
\hline C & $58 \mathrm{X}$ & 14 & 1750 & 511.5 & 521.0 & 9.5 & 7.33 & 77.1 \\
\hline C & $59 \mathrm{X}$ & 14 & 1935 & 521.0 & 530.5 & 9.5 & 9.77 & 103.0 \\
\hline C & $60 x$ & 14 & 2130 & 530.5 & 540.0 & 9.5 & 3.97 & 41.8 \\
\hline C & $61 X$ & 14 & 2300 & 540.0 & 549.5 & 9.5 & 3.10 & 32.6 \\
\hline C & $62 X$ & 15 & 0045 & 549.5 & 559.0 & 9.5 & 1.16 & 12.2 \\
\hline C & $63 X$ & 15 & 0230 & 559.0 & 568.5 & 9.5 & 3.31 & 34.8 \\
\hline C & $64 X$ & 15 & 0415 & 568.5 & 578.0 & 9.5 & 4.95 & 52.1 \\
\hline C & $65 \mathrm{X}$ & 15 & 0630 & 578.0 & 587.5 & 9.5 & 8.42 & 88.6 \\
\hline C & $66 \mathrm{X}$ & 15 & 0830 & 587.5 & 597.0 & 9.5 & 6.55 & 68.9 \\
\hline C & $67 X$ & 15 & 1015 & 597.0 & 606.5 & 9.5 & 3.36 & 35.3 \\
\hline C & $68 \mathrm{X}$ & 15 & 1200 & 606.5 & 616.0 & 9.5 & 8.36 & 88.0 \\
\hline C & $69 \mathrm{X}$ & 15 & 1345 & 616.0 & 625.5 & 9.5 & 4.41 & 46.4 \\
\hline C & $70 x$ & 15 & 1520 & 625.5 & 635.0 & 9.5 & 9.42 & 99.1 \\
\hline C & $71 X$ & 15 & 1700 & 635.0 & 644.5 & 9.5 & 8.03 & 84.5 \\
\hline C & $72 X$ & 15 & 1840 & 644.5 & 654.0 & 9.5 & 3.64 & 38.3 \\
\hline C & $73 x$ & 15 & 2010 & 654.0 & 663.5 & 9.5 & 2.56 & 26.9 \\
\hline C & $74 \mathrm{X}$ & 15 & 2140 & 663.5 & 673.0 & 9.5 & 2.19 & 23.0 \\
\hline C & $75 X$ & 15 & 2320 & 673.0 & 682.5 & 9.5 & 5.63 & 59.2 \\
\hline C & $76 x$ & 16 & 0115 & 682.5 & 692.0 & 9.5 & 6.04 & 63.6 \\
\hline C & $77 X$ & 16 & 0305 & 692.0 & 701.5 & 9.5 & 9.74 & 102.0 \\
\hline C & $78 \mathrm{X}$ & 16 & 0530 & 701.5 & 711.0 & 9.5 & 9.57 & 101.0 \\
\hline C & $79 X$ & 16 & 0800 & 711.0 & 720.5 & 9.5 & 9.31 & 98.0 \\
\hline C & $80 \mathrm{X}$ & 16 & 0950 & 720.5 & 730.0 & 9.5 & 5.01 & 52.7 \\
\hline C & $81 X$ & 16 & 1145 & 730.0 & 739.5 & 9.5 & 1.30 & 13.7 \\
\hline C & $82 X$ & 16 & 1345 & 739.5 & 749.0 & 9.5 & 1.23 & 12.9 \\
\hline C & $83 \mathrm{X}$ & 16 & 1545 & 749.0 & 758.5 & 9.5 & 1.15 & 12.1 \\
\hline C & $84 X$ & 16 & 1755 & 758.5 & 768.0 & 9.5 & 4.61 & 48.5 \\
\hline C & $85 X$ & 16 & 2010 & 768.0 & 777.5 & 9.5 & 9.63 & 101.0 \\
\hline C & $86 x$ & 16 & 2205 & 775.5 & 787.0 & 9.5 & 0.57 & 6.0 \\
\hline C & $87 X$ & 16 & 2345 & 787.0 & 796.5 & 9.5 & 3.39 & 35.7 \\
\hline C & $88 \mathrm{X}$ & 17 & 0302 & 796.5 & 806.0 & 9.5 & 1.33 & 14.0 \\
\hline C & $89 X$ & 17 & 0505 & 806.0 & 809.2 & 3.2 & 0.80 & 25.0 \\
\hline C & $90 \mathrm{X}$ & 17 & 0750 & 809.2 & 818.7 & 9.5 & 2.02 & 21.2 \\
\hline \multirow[t]{2}{*}{ C } & $91 X$ & 17 & 1100 & 818.7 & 828.2 & 9.5 & 6.21 & 65.3 \\
\hline & & & & & & $\overline{814.7}$ & $\overline{480.20}$ & \\
\hline
\end{tabular}

manganese migrating to oxidizing environments where it precipitates as $\mathrm{MnO}_{2}$, and iron migrating to reducing environments where it precipitates as $\mathrm{FeS}_{2}$ and/or its precursors. Color value and $\mathrm{Fe}_{2} \mathrm{O}_{3}$ also show a moderately significant correlation; higher $\mathrm{Fe}_{2} \mathrm{O}_{3}$ leading to darker colors. This is also a function of the abundance of iron sulfide minerals.

The most enigmatic relationship between elements results from comparing the $\mathrm{MgO} / \mathrm{Al}_{2} \mathrm{O}_{3}$ ratio to the $\mathrm{K}_{2} \mathrm{O} / \mathrm{Al}_{2} \mathrm{O}_{3}$ ratio. By normalizing to $\mathrm{Al}_{2} \mathrm{O}_{3}$, the effects of dilution of the raw concentrations by quartz and calcium carbonate are eliminated, and the variation in the aluminous (presumably clay) phase(s?) can be studied. The $\mathrm{MgO}$ in the calcium carbonate component is not important; in fact, $\mathrm{CaO}$ and $\mathrm{MgO}$ are not correlated in these samples.

The correlation between $\mathrm{MgO} / \mathrm{Al}_{2} \mathrm{O}_{3}$ and $\mathrm{K}_{2} \mathrm{O} / \mathrm{Al}_{2} \mathrm{O}_{3}$ is fairly strong $\left(\mathrm{r}^{2}=0.808\right)$ and unexpectedly, positive. It was expected that an inverse correlation would exist between the two, representing the mixing of $\mathrm{Mg}$-rich, $\mathrm{K}_{2} \mathrm{O}$-poor smectites and $\mathrm{K}_{2} \mathrm{O}$ rich, MgO-poor illites. Phengite, a form of illite, contains magnesium in the octahedral layers, where it substitutes for aluminum. This leads to a positive correlation between $\mathrm{MgO} / \mathrm{Al}_{2} \mathrm{O}_{3}$ and $\mathrm{K}_{2} \mathrm{O} / \mathrm{Al}_{2} \mathrm{O}_{3}$ in phengite, but at compositions much more potash-rich than those measured here. The $\mathrm{MgO}$ and $\mathrm{K}_{2} \mathrm{O}$-rich component may be biotite but the correct explanation of the positive correlation between magnesium and potassium in these samples is unknown and awaits a comparison with X-ray diffraction data.

In conclusion, there are three important components in these sediments: calcium carbonate, quartz, and an alumino-silicate phase in which $\mathrm{MgO}$ and $\mathrm{K}_{2} \mathrm{O}$ are positively correlated. A secondary component is represented by the redox sensitive elements, manganese and iron, which migrate in response to chemical conditions in the pore waters.

Additional data is required for chlorine, which would permit the correction of other concentrations for occluded sea salt, and for sulfur, to help understand the distribution of iron.

\section{BIOSTRATIGRAPHY}

\section{General}

Site 717 yielded usable silicious microfossils-radiolarians, diatoms, silicoflagellates-only in the upper part of the section, 


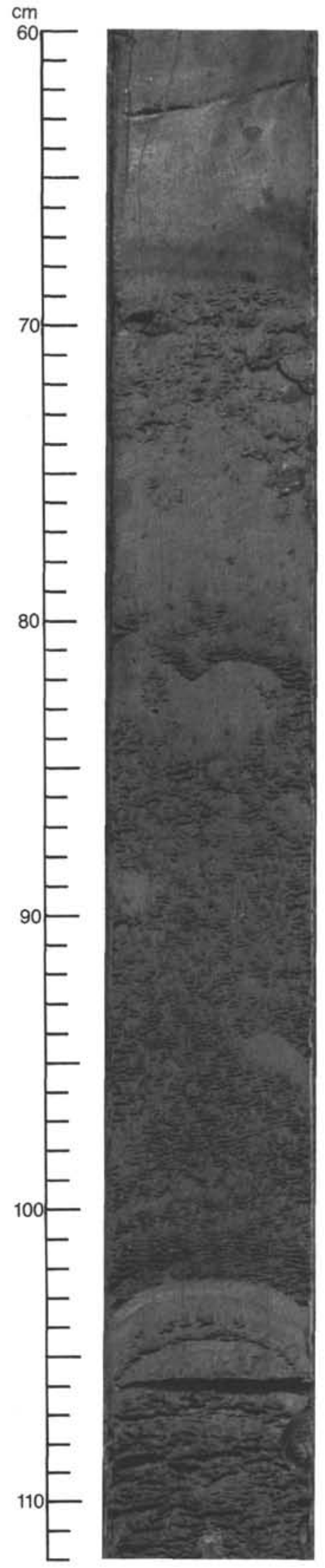

Figure 3. Photograph of a silt-mud turbidite (Sample 116-717B-2H-3, $60-112 \mathrm{~cm})$. i.e., Cores 116-717B-1H, -717C-26X, and -717C-27X. Radiolarians and silicoflagellates are generally poorly preserved, while diatoms are represented by delicate forms, most of them, however, broken. The siliceous microfossils indicated a PliocenePleistocene age. Pyritized diatoms also were recovered sporadically at several levels in the section. These remains, when complete, can easily be identified to the species level because the extremely fine pyrite coating did not alter the finest structure of the diatom frustules. Low diversity of recovered diatom assemblages is probably caused by selective dissolution of frustules prior to pyritization. Siliceous skeletons of radiolarians and polyaxial sponge spicules are nearly completely replaced with pyrite and yet their fine skeletal structures are preserved.

Calcareous microfossils are found in much of the cored interval but their occurrence is sporadic. They occur most consistently and in greatest abundance, although all of the assemblages are severely corroded, as the residue of the most solutionresistant species. Nevertheless, the biostratigraphy is based primarily on the calcareous nannofossils. Planktonic foraminifers occur more rarely in the section, often together with the calcareous nannofossils, and consist nearly always of corrosionfragmented specimens of large species, or of very small, possibly juvenile specimens, neither yielding much insight into the history of the sediments at this site. Benthic foraminifers occur more consistently than planktonic species. These too, however, are represented by very small, often extremely delicate species of limited usefulness for interpreting the sediment.

In nearly every sample the redeposition of some micro- and nannofossils is apparent from the age inconsistencies in the assemblage. Therefore, all ages must be suspect to some degree. It is reasonable to think that many of the assemblages are redeposited, probably penecontemporaneously in most instances. Consequently all ages should be considered maximum ages, and the true age may, in fact, be younger than the age assigned to it here.

\section{Radiolarians}

Radiolarians are generally absent or poorly preserved throughout the cores at Site 717 and age assignments were not possible for most samples. Age assignment was only possible for the Sample 116-717B-1H, CC which contained an abundant moderately preserved assemblage including the following diagnostic taxa: Spongaster tetras, Theocorythium trachelium trachelium, Didymocyrtis tetrathalamas, Pterocanium praetextum, Lithopera bacca, Collosphaera tuberosa, and Phormosticoartus corbula. Although looked for, Buccinosphaera invaginata was not found. This sample may be assigned to the Collosphaera tuberosa Zone of Quaternary age.

The remainder of the sporadic radiolarian occurrences were concentrated in samples from Cores 116-717C-21X, 116-717C27X, and 116-717C-29X including the following samples: 116717C-21X, CC; 116-717C-26X, CC; 116-717C-27X-1, 24-26 cm; $116-717 \mathrm{C}-27 \mathrm{X}-5,12-14 \mathrm{~cm} ; 116-717 \mathrm{C}-27 \mathrm{X}-5,32-34 \mathrm{~cm} ; 116-$ 717C-27X-5, 70-72 cm; 116-717C-27X-5, 91-95 cm; 116-717C$27 \mathrm{X}-5,116-118 \mathrm{~cm} ; 116-717 \mathrm{C}-29 \mathrm{X}, \mathrm{CC} ; 116-717 \mathrm{C}-59 \mathrm{X}-2,34-$ $36 \mathrm{~cm} ; 116-717 \mathrm{C}-59 \mathrm{X}-4,11-13 \mathrm{~cm}$. In these samples radiolarian abundances are low and most specimens are fragmented and pyritized, which makes species identification difficult. Among these Sample 116-717C-27X-1, 24-26 cm, contains a moderately diverse assemblage including Botryocyrtis scutum, Cornutella profunda, Tetrapyle octacantha, Carpocanarium papillosum, Spirocyrtis cf. subscalaris, Carpocanarium sp. D (Ling, 1975), Theocalyptra sp., and several spongodiscid species.

\section{Silicoflagellates}

Silicoflagellates were encountered only in three samples, but no definite age assignment can be made. Sample 116-717C- 

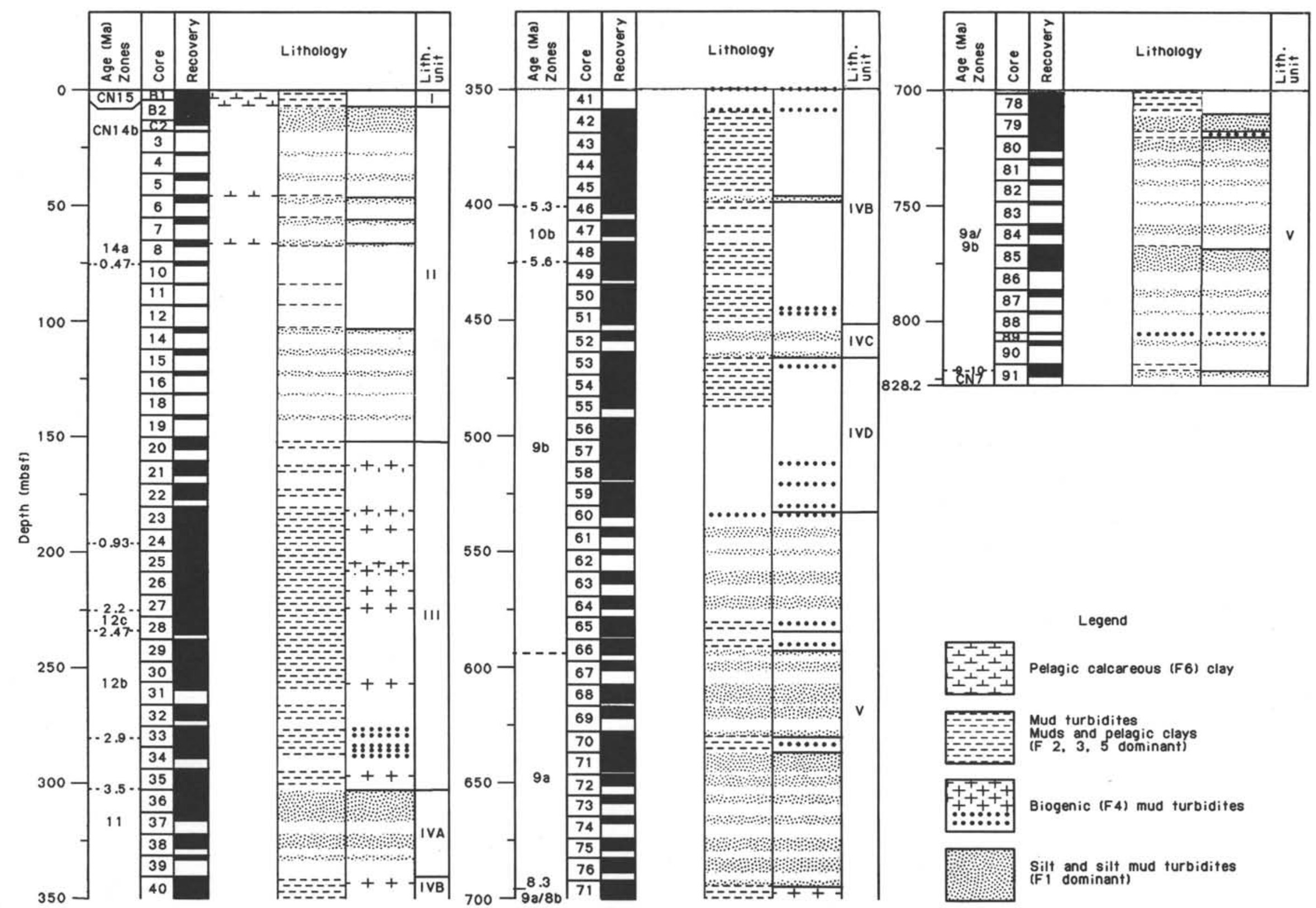

Figure 4. Lithology of Site 717.
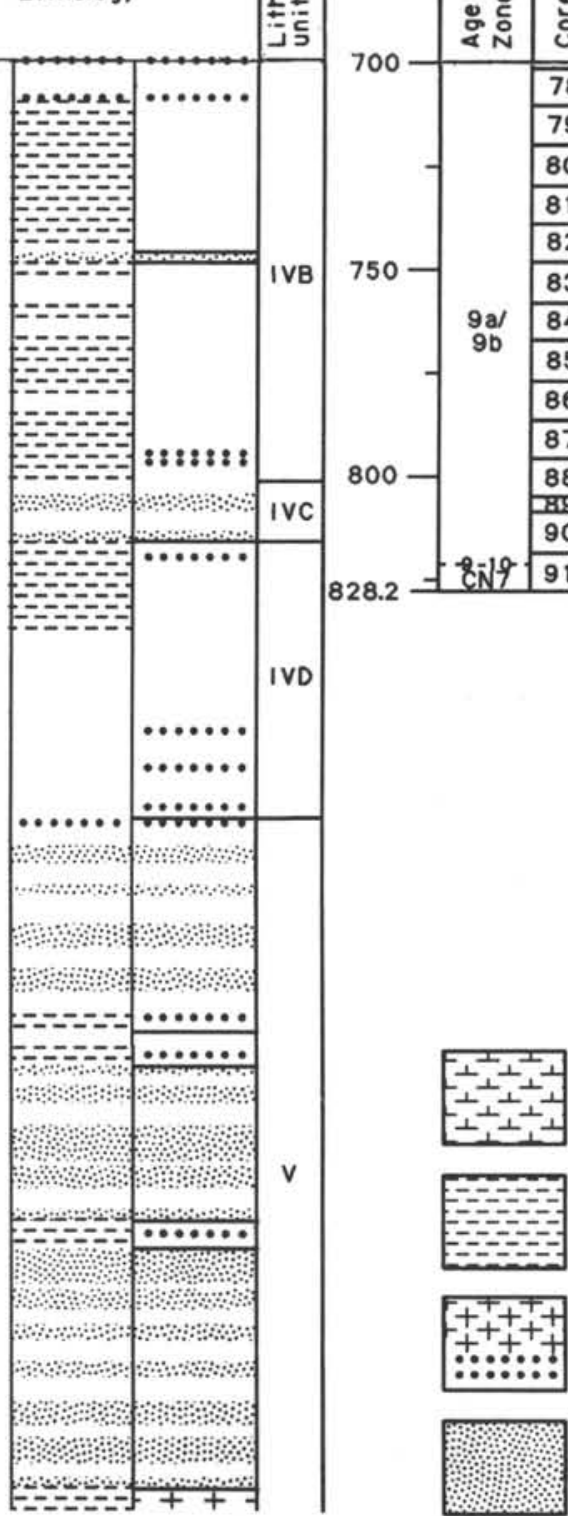

Pelagic calcareous (F6) clay

Mud turbidites

Muds and pelagic clays
(F 2, 3, 5 dominant)

Biogenic (F4) mud turbidites

$\because:::$ :

Silt and silt mud turbidites 


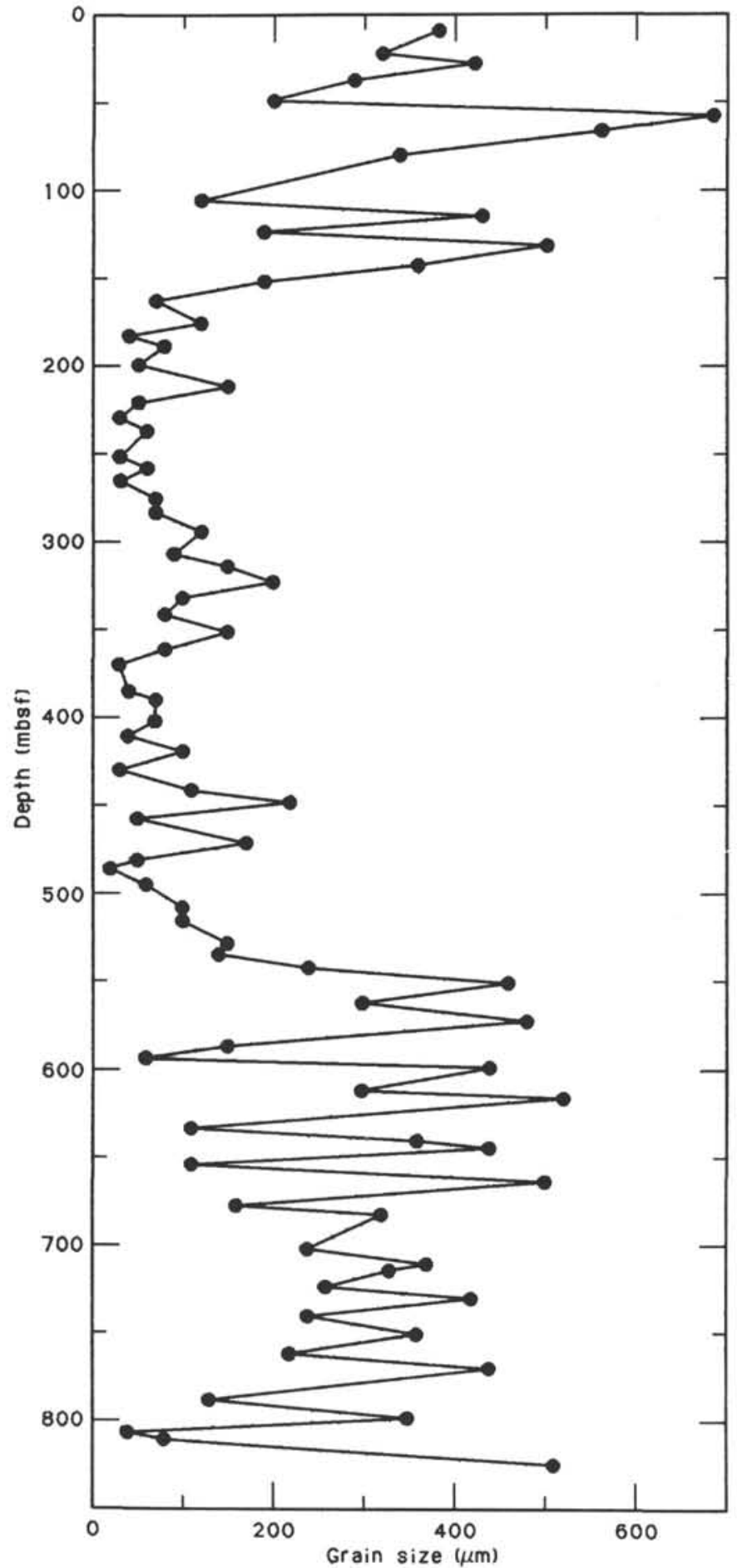

Figure 5. Maximum grain size vs. depth, Site 717.

$27 \mathrm{X}-1,24-26 \mathrm{~cm}$, contains few Mesocena quadrangula and rare Distephanus sp. A (Perch-Nielsen, 1985) and Dictyocha longa. In the Tropical Pacific the first appearance of $M$. quadrangula is in the late Miocene and the species reached an acme in the middle Pleistocene before its disappearance at about $1 \mathrm{Ma}$. (Bukry, 1985; Locker and Martini, 1986). Sample 116-717C27X-5, 91-95 cm, contains rare specimens of Dictyocha? delicata. Sample 116-717C-78X-4, 92-94 cm, contains rare Dictyocha breviospina ausonia.

Approximately $50 \%$ of silicoflagellate specimens in Sample 116-717C-27X-1, 24-26 cm, and most of those in Samples 116-

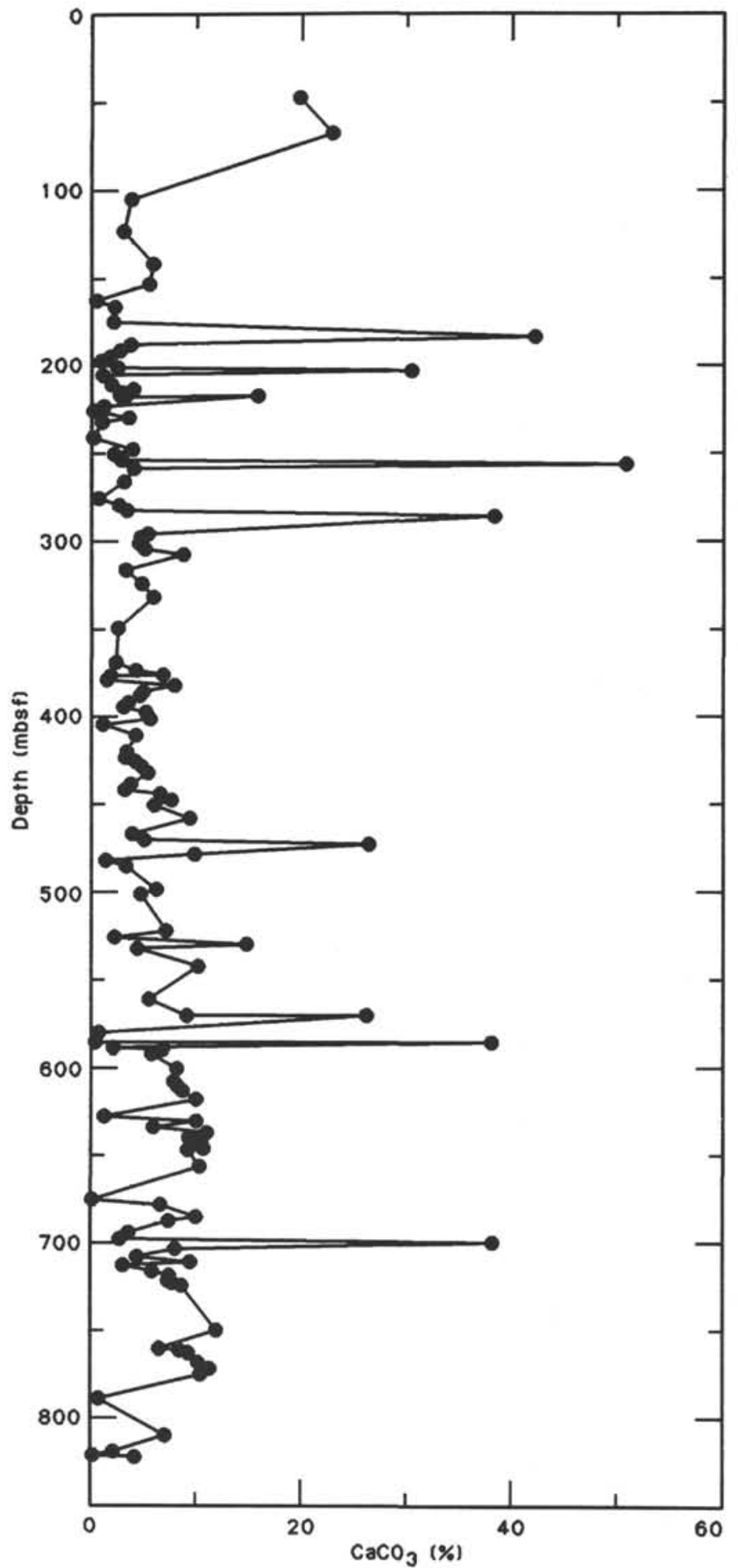

Figure 6. Carbonate content vs. depth, Site 717.

717C-27-5, 91-95 cm, and 116-717C-78X-4, 92-94 cm, are pyritized. In all three cores silicoflagellates coexist with pyritized radiolarians.

\section{Diatoms}

Diatoms are rare to absent in most samples examined from Site $717 \mathrm{C}$. They are present mainly in the soft dark-brown or yellow-green biogenic turbidites along with other siliceous microfossils. Most abundant are spiculae of sponges, endoskeletons of radiolarians, silicoflagellates, ebridians, and occasionally, especially in the upper cores, terrestrial phytolithes. How- 
Table 2. Major element X-ray fluorescence analysis data, Hole 717C.

\begin{tabular}{|c|c|c|c|c|c|c|c|c|c|c|c|c|c|}
\hline Sample & $\mathrm{SiO}_{2}$ & $\mathrm{TiO}_{2}$ & $\mathrm{Al}_{2} \mathrm{O}_{3}$ & $\mathrm{Fe}_{2} \mathrm{O}_{3}$ & $\mathrm{MnO}$ & $\mathrm{MgO}$ & $\mathrm{CaO}$ & $\mathrm{Na}_{2} \mathrm{O}$ & $\mathrm{K}_{2} \mathrm{O}$ & $\mathrm{P}_{2} \mathrm{O}_{5}$ & Total & LOI & Color \\
\hline \multicolumn{14}{|l|}{$116-717 \mathrm{C}$ - } \\
\hline $28 X-5,90-92$ & 41.22 & 0.55 & 12.30 & 7.66 & 0.51 & 2.43 & 29.19 & 1.40 & 1.85 & 0.28 & 97.39 & 23.23 & 6.0 \\
\hline $28 X-5,108-112$ & 20.27 & 0.24 & 6.22 & 3.64 & 1.35 & 0.00 & 64.62 & 0.00 & 0.09 & 1.01 & 97.44 & 35.56 & 7.0 \\
\hline $30 \times-1,15-19$ & 59.69 & 0.97 & 20.42 & 9.51 & 0.74 & 3.51 & 1.76 & 1.78 & 3.86 & 0.11 & 102.35 & 8.30 & 5.0 \\
\hline $30 X-1,126-131$ & 55.90 & 1.76 & 20.60 & 12.57 & 0.19 & 2.91 & 1.85 & 1.97 & 2.13 & 0.11 & 99.99 & 12.27 & 3.0 \\
\hline $30 \times-2,80-85$ & 53.93 & 1.61 & 20.27 & 12.98 & 0.18 & 3.03 & 2.44 & 1.88 & 2.14 & 0.12 & 98.58 & 12.12 & 2.5 \\
\hline $30 X-3,10-15$ & 27.20 & 0.43 & 10.44 & 7.48 & 0.53 & 1.07 & 39.21 & 1.33 & 1.13 & 0.60 & 89.42 & 28.02 & 3.0 \\
\hline $30 X-3,105-110$ & 58.91 & 0.87 & 19.75 & 8.63 & 0.24 & 3.40 & 2.73 & 1.65 & 3.85 & 0.13 & 100.16 & 8.31 & 6.0 \\
\hline $33 \mathrm{X}-2,48-53$ & 65.73 & 0.81 & 16.75 & 6.36 & 0.18 & 3.07 & 2.76 & 1.65 & 3.95 & 0.11 & 101.37 & 6.30 & 5.0 \\
\hline $33 X-3,118-123$ & 37.38 & 0.69 & 14.60 & 7.10 & 0.42 & 1.35 & 31.09 & 1.47 & 1.51 & 0.41 & 96.02 & 25.46 & 4.0 \\
\hline $33 X-5,21-26$ & 58.30 & 0.95 & 20.27 & 9.46 & 0.16 & 3.54 & 0.83 & 1.68 & 4.14 & 0.14 & 99.47 & 7.85 & 7.0 \\
\hline $34 X-1,45-49$ & 59.41 & 0.94 & 19.73 & 8.56 & 0.18 & 3.73 & 1.44 & 1.82 & 4.24 & 0.10 & 100.15 & 7.45 & 5.0 \\
\hline $34 X-1,94-98$ & 62.18 & 0.66 & 13.38 & 9.74 & 0.21 & 3.15 & 3.56 & 1.84 & 3.29 & 0.09 & 98.10 & 5.36 & 6.0 \\
\hline $34 X-2,94-99$ & 55.35 & 1.73 & 22.13 & 13.80 & 0.14 & 2.60 & 1.28 & 2.07 & 1.92 & 0.10 & 101.12 & 19.62 & 4.0 \\
\hline $34 X-2,140-145$ & 61.83 & 0.82 & 17.45 & 8.29 & 0.16 & 3.66 & 2.51 & 1.68 & 4.20 & 0.11 & 100.71 & 6.82 & 6.0 \\
\hline $44 X-2,48-53$ & 53.87 & 1.48 & 20.79 & 11.59 & 0.15 & 2.44 & 4.75 & 1.69 & 2.22 & 0.11 & 99.09 & 14.13 & 2.5 \\
\hline $45 X-6,130-136$ & 55.52 & 1.62 & 22.28 & 12.56 & 0.16 & 2.71 & 1.08 & 1.70 & 2.06 & 0.09 & 99.78 & 13.42 & 2.5 \\
\hline
\end{tabular}

ever, two samples from Cores 116-717C-26X and 116-717C-27X contain some moderately preserved and fairly abundant diatom frustules of pelagic diatoms. Samples from Cores 116-717C26X and 116-717C-27X contain an admixture of displaced, neritic diatoms. Below this level only isolated or rare specimens of robust taxa were found (Cores 116-717C-30X, -717C-56X $-717 \mathrm{C}-59 \mathrm{X},-717 \mathrm{C}-65 \mathrm{X},-717 \mathrm{C}-66 \mathrm{X},-717 \mathrm{C}-70 \mathrm{X},-717 \mathrm{C}-78 \mathrm{X}$, and $-717 \mathrm{C}-82 \mathrm{X})$. With very rare exceptions, especially below the level of Core 116-717C-27X, all diatoms are pyritized.

Few species present in the younger samples (Cores 116-717C$26 \mathrm{X}$ to $116-717 \mathrm{C}-30 \mathrm{X})$; Actinocyclus divisus, Coscinodiscus africanus, Thalassiosira oestrupii, and Ethmodiscus rex, have biostratigraphic and paleoceanographic significance even in such a depauperate assemblage. The first three, $A$. divisus, $C$. africanus, and $T$. oestrupii, have been recorded in the Indian and $\mathrm{Pa}$ cific Oceans from Pleistocene and Pliocene age sediments.

Ethmodiscus rex is well known for its role in formation of the Ethmodiscus ooze. Its stratigraphic range is long, but in Indian Ocean sediments it is present in abundance, although intermittently, only during Pleistocene and Pliocene. Therefore, its presence in Hole $717 \mathrm{C}$ may reflect its true contribution to the formation of pelagic Ethmodiscus-rich sediments down to the level of Core 116-717C-30X. From these originally deposited sediments, only species most abundant and resistant to dissolution were preserved. Therefore, the section including the studied samples of Cores 116-717C-26X to $-30 \mathrm{X}$ are no older than Pliocene.

In Section 116-717C-78X-4 from the older part of the hole, several fragments and one well-preserved valve of Coscinodiscus temperi var. delicata were encountered. Stratigraphic distribution of this diatom has been shown to be restricted to the interval 10-12 m.y. in the low-latitude Pacific.

The majority of biogenic siliceous remains in Hole 717C, especially those below 225 mbsf (Core 116-717C-27X), are pyritized; diatoms appear to be covered with a fine pyrite coating revealing the finest structural details. Elemental analysis of pyritized diatoms reveals the presence of silica. It is assumed that pyritization occurred following the onset of postdepositional dissolution of biogenic silica, and the fact that any hydrous siliceous microfossils (diatoms, silicoflagellates) are present at all in these sediments may be due to the pyrite seal.

\section{Foraminifers}

Although 170 samples were examined, Hole $717 \mathrm{C}$ yielded only a few poor to moderately preserved specimens which allow a biostratigraphic assignment. Unfortunately, these samples are also strongly affected by dissolution and contain only poor-di- versity assemblages. Foraminifers are rare or absent in most parts of the sequence. Abundant and well-preserved foraminifer assemblages have been found only in biogenic turbidites.

\section{Pleistocene}

The interval 116-717C-1W to $-717 \mathrm{C}-16 \mathrm{X}, \mathrm{CC}$, is referred to the Pleistocene, based on the occurrence of Globoroalia truncatulinoides in Section 116-717C-16X, CC. The interval below this core down to Core $116-717 \mathrm{C}-28 \mathrm{X}$ is only tentatively referred to the Pleistocene. In fact, the taxa occurring there, Globorotalia tumida tumida, G. menardii, G. menardii cultrata, Sphaeroidinella dehiscens, Neogloboquadrina dutertrei, Pulleniatina obliquiloculata, and Globigerina conglomerata, are particularly common in the Pleistocene but not restricted to this epoch, being also present in the Pliocene.

\section{Pliocene}

The interval $116-717 \mathrm{C}-29 \mathrm{X}-3,11-13 \mathrm{~cm}$, to $116-717 \mathrm{C}-47 \mathrm{X}$, $\mathrm{CC}$, yields Globoquadrina altispira altispira, Globigerinoides obliquus, and Sphaeroidinellopsis seminulina, taxa whose range encompasses the late Miocene to early Pliocene. However, Sample 116-717C-40X-3, 52-54 cm yields Globorotalia margaritae, which indicated an early Pliocene age (Zones N18-N19).

\section{Miocene}

Based on the planktonic foraminifer occurence, a Miocene age is recognized only in two sections: $116-717 \mathrm{C}-70 \mathrm{X}, \mathrm{CC}$, and 116-717C-75X, CC. The latter, which contains Globigerinoides obliquus extremus, G. bulloideus, Globigerina nepenthes, Globoquadrina altispira altispira, Globorotalia cf. merotumida, is referred to the late Miocene with strong certainty.

All the samples downhole from this level are barren or contain very rare foraminifers of no stratigraphic utility.

\section{Environmental Considerations}

From the environmental point of view the foraminifer analysis, carried out mainly on the core catchers and on supplementary samples from the cores, gives the following indications:

1. Pelagic oozes (Samples 116-717C-10X-1, 70-72 cm; -717C$22 \mathrm{X}-5,37-39 \mathrm{~cm} ;-717 \mathrm{C}-24 \mathrm{X}-5,20-22 \mathrm{~cm}$; $-717 \mathrm{C}-25 \mathrm{X}-4,112-$ $114 \mathrm{~cm} ;-717 \mathrm{C}-38 \mathrm{X}-4,40-44 \mathrm{~cm}$ ) were deposited below the lysocline. They contain mainly fragmented planktonic foraminifer tests and somewhat better-preserved benthic ones. Several other samples completely devoid of planktonic foraminifers, and yielding only few benthic forms together with phosphatic remains or pyritized siliceous tests, are presumed to have been deposited 
below the CCD (e.g., Section 116-717C-32X, CC; Sample 116717C-34X-1, 133-135 cm; Section 116-717C-43X, CC; etc).

2. Downslope displacement is documented by occurrence of (a) shelf benthic foraminifers such as Ammonia beccarii, Elphidium spp., etc., particularly in the upper part of the sequence (lithologic Units I and II, Sections 116-717C-3X, CC; -717C$4 \mathrm{X}, \mathrm{CC}$; -717C-5X, CC; -717C-24X, CC); (b) plant debris, echinoid remains, mollusk fragments; (c) abundant size-selected, very small foraminifers whose good preservation suggests rapid transport and burial (Cores 116-717C-20X to -717C-31X).

3. Evidence of reworking has also been detected in Sections 116-717C-15X, CC; 116-717C-16X, CC; and 116-717C-28X, CC.

\section{Calcareous Nannofossils}

Coccoliths, discoasters, and associated forms occur sporadically throughout the section. In some instances they occur in what appear to be thin, pelagic ooze layers; often they are preserved in thin black or green layers of fine-grained sediments, between sandy-silty turbidite beds. In many cases rare nannofossils are found as part of the fine-grained matrix or the fine silt- to clay-size fraction in the sandy, silty turbidites. In the latter case assemblages are always sparse and not always diagnostic. All of the nannofossil assemblages recovered are residual; they show strong evidence of corrosion and dissolution, with only the most resistant species remaining recognizable. Fortunately, many of the key late-Neogene index species, the discoasters, are among the most solution-resistant elements of the assemblage.

The zonal designation used throughout this section is that of Okada and Bukry (1980). Where appropriate, that zonation will be modified to express more clearly the age of a particular level, expanding zones where greater resolution can be achieved than is indicated in the zonation, contracting zones where required by the limitations of the assemblage recovered. The ages assigned to the various depths in the hole are derived principally from the compilation of Berggren et al. (1985). Given the sparseness of the nannofossils and the sometimes inconveniently poor core recovery, these age assignments are not as precise as can be achieved in pelagic sections.

\section{Biostratigraphic Evaluation}

One core was recovered in Hole 717A and it yielded late Pleistocene nannofossils. Sections 116-717A-1H-1 through 116717A-1H-3 contain Emiliania huxleyi, which assigns this interval to Zone CN15 and makes it not older than 0.28 m.y. Section 4 yielded no nannofossils, but the core catcher yielded an assemblage without Emiliania huxleyi and without Pseudoemiliania lacunosa, but with Gephyrocapsa oceanica. This combination indicates that this level belongs to nannofossil Zone CN14b. The two cores recovered from Hole 717B also belong to Zone $\mathrm{CN} 14 \mathrm{~b}$, although the core catcher of Core 116-717B-2H yielded only a very poor, nondiagnostic assemblage.

Hole $717 \mathrm{C}$ was washed to $13.5 \mathrm{~m}$ before the first core was taken. The first core from this hole, designated as Core 116$717 \mathrm{C}-2 \mathrm{H}$, starts within Zone $\mathrm{CN} 14 \mathrm{~b}$ and this same zone continues into Sample 116-717C-8X-2, 59-61 cm (about $67 \mathrm{mbsf}$ ). Pseudoemiliania lacunosa occurs consistently from Sample 116$717 \mathrm{C}-8 \mathrm{X}, \mathrm{CC}$, downward and the highest occurrence of this species marks the top of Zone $\mathrm{CN14a}$. The age associated with this datum is 0.47 m.y. Zone CN14a, the Pseudoemiliania lacunosa Zone, continues to Core 116-717C-24X-5, 20-22 cm (about $196.2 \mathrm{mbsf}$ ). The assemblages down to this level are mostly sparse but typically of late Pleistocene aspect, although contamination by redeposited older-mostly Pliocene-species is common. The assemblage in Section 116-717C-24, CC is dominated overwhelmingly by small Gephyrocapsa and lacks Gephyrocapsa oceanica. This level is, therefore, assignable to the small Gephyrocapsa acme interval and is equivalent to the upper part of Zone $\mathrm{CN} 13 \mathrm{~b}$. The top of the small Gephyrocapsa acme interval corresponds closely to the top of the Jaramillo magnetic event and has an estimated age of $0.93 \mathrm{~m}$.y. Thus, approximately the upper $197 \mathrm{~m}$ of section at this site represents only the younger half of the Pleistocene.

Cores 116-717C-25X and -717C-26X yielded rare to common nannofossils at several levels, the assemblages being chiefly of early Pleistocene aspect although some contain late Pliocene components such as Discoaster brouweri and abundant small Reticulofenestra. The Pliocene species are judged redeposited and the cores are assigned an early Pleistocene age (Zone CN13). Section 116-717C-26X, CC contains particularly abundant nannofossils, but the assemblage is a mixture of late Miocene, Pliocene, and early Pleistocene components. The age derived from this assemblage is judged unreliable because it is too old relative to several subjacent samples. The top of Zone CN12c is next below in Section 116-717C-27X-5, $100 \mathrm{~cm}$, marked by the highest occurrence of Discoaster pentaradiatus. By inference, the Pliocene-Pleistocene boundary is between Sections 116-717C-26X, $\mathrm{CC}$ and $-717 \mathrm{C}-27 \mathrm{X}-5,100 \mathrm{~cm}$ within an unpromising lithology. Next is the top of Zone CN12b in Sample 116-717C-28X-5, $114-116 \mathrm{~cm}$, marked by the highest occurrence of Discoaster asymmetricus (which is equivalent to the highest occurrence of Discoaster surculus). This is followed by the top of Zone CN12a in Section 116-717C-28X-5, $141 \mathrm{~cm}$, marked by the highest occurrence of Discoaster variabilis. The ages associated with the upper limit of each zone are as follows: Zone CN12d-1.9 m.y; Zone CN12c-2.2 m.y; Zone CN12b-2.47 m.y; Zone CN12a2.9 m.y. This succession of late Pliocene zones should be viewed with a certain amount of caution because it may be based on redeposited or mixed assemblages, some of which are only marginally datable. The very uneven thickness of the late Pliocene zones reinforces the above caution. The late Pliocene continued downward to Section 116-717C-40X, CC although a layer particularly rich in nannofossils and containing both Sphenolithus abies and Reticulofenestra pseudoumbilica occurs at Section 116-717C-35X, CC. However, this layer is succeded downward by the late Pliocene assemblages and is therefore considered to be redeposited.

Next below is the top of Zone CN11 in Section 116-717C$40 \mathrm{X}, \mathrm{CC}$, marked by the highest consistent occurrence of Sphenolithus abies and Reticulofenestra pseudoumbilica. This corresponds approximately to the midpoint of the Pliocene, or very close to the 3.5-m.y. level. Much of the Pliocene below this level cannot be readily broken down into zones because of the generally less-reliable nature of early Pliocene markers and the even less-reliable record obtained at this site. Zone $\mathrm{CN1Ob}$ is identified in Samples 116-717C-46X, CC, and 116-717C-47X, CC, based on the presence of Ceratolithus armatus, a surrogate marker in the absence of other ceratoliths. In any case, the above marks the base of the Pliocene in this section because the very next lower sample, from Sample 116-717C-48X-6, 41-43 $\mathrm{cm}$, contains Discoaster quinqueramus, the marker species for the late Miocene Zone CN9b. The precise position of the Miocene/Pliocene boundary within Core $116-717 \mathrm{C}-48 \mathrm{X}$ is uncertain. Zone $\mathrm{CN} 10 \mathrm{a}$, which is thought to be the the youngest identifiable nannozone within the Miocene, was not recognized and must, in any case, be of very short duration.

The next lower useful datum is the occurrence of Amaurolithus amplificus in Section 116-717C-52X-3; $76 \mathrm{~cm}$ and Sample $116-717 \mathrm{C}-54 \mathrm{X}-5,106-108 \mathrm{~cm}$, which indicates an age not greater than 5.9 m.y. for these levels.

The late Miocene contains few marker species at this site and none is sufficiently consistent in occurrence to be considered totally reliable. One possible useful point may be the occurrence of Discoaster neohamatus in Section 116-717C-77X-3, $130 \mathrm{~cm}$, 
which indicates this level as assignable to Zone $\mathrm{CN} 8 \mathrm{~b}$ which, in turn, implies an age between 8.2 and 8.4 m.y.

The oldest useful nannofossil date is from the base of the section, in Section 116-717C-91X-2, $20 \mathrm{~cm}$, where a residual but diagnostic assemblage was recovered, which contains Discoaster hamatus, Catinaster coalitus, and Discoaster bellus. These species place the sample within the top of Zone $\mathrm{CN} 7$, with an associated age of about $9.5 \mathrm{~m}$.y.

\section{Sediment Accumulation Rate}

The ages derived from paleontological analysis - chiefly nannofossils-and the corresponding depths are given in tabular form in Table 3. They are also given on a depth vs. age plot in Figure 7, to yield a sediment accumulation rate curve. Sediment accumulation is greatest for the late Pleistocene, particularly for the interval from 0.47 to $0.93 \mathrm{~m}$.y., when sediment accumulated at the rate of $260 \mathrm{~m} / \mathrm{m}$.y. (Not surprisingly, this corresponds to the maximum density of massive turbidites.) The rate for the latest Pleistocene is somewhat lower at approximately $145 \mathrm{~m} /$ m.y. In marked contrast is the accumulation rate for the early Pleistocene, which is less than $20 \mathrm{~m} / \mathrm{m}$.y. Indeed, there may be a significant hiatus in the early Pleistocene, as no sediments of this age were identified. During the Pliocene, sediment accumulated at an average rate of about $55 \mathrm{~m} / \mathrm{m}$.y., although there seems to be considerable variation around that average. During the late Miocene, sediment accumulated at a higher rate also, especially during the latest Miocene (Messinian), with an overall average rate of approximately $100 \mathrm{~m} / \mathrm{m} . \mathrm{y}$.

\section{ORGANIC GEOCHEMISTRY}

The organic geochemical program at Site 717 consisted of measurements of hydrocarbon gases, organic carbon, and RockEval pyrolysis characteristics on selected samples. In addition, interstitial water and sediment samples were collected for shorebased organic geochemical studies.

\section{Hydrocarbon}

\section{Vacutainer Gases}

Vacutainers were prepared by using the laboratory freeze dryer to remove contaminants and to establish a vacuum of about 40 in. $\mathrm{Hg}$ following the method of Kvenvolden and McDonald (1986). Gases within the core liner were recovered directly by means of a hollow punch equipped with a valve. After the punch penetrated the core liner, gas vented through the valve into a 20 - $\mathrm{mL}$ vacutainer. The gases were analyzed by gas chromatography (Hach-Carle Gas Chromatograph) and the results are listed on Table 4. Gas pockets were observed only in Cores 116-717C-

\begin{tabular}{|c|c|}
\hline Depth (mbsf) & Age (m.y.) \\
\hline 67.5 & 0.47 \\
\hline 198 & 0.93 \\
\hline 205 & 1.9 \\
\hline 224 & 2.2 \\
\hline 233 & 2.47 \\
\hline 282 & 2.9 \\
\hline 321.5 & 3.5 \\
\hline 404 & 5.3 \\
\hline 425 & 5.6 \\
\hline 482 & 5.9 \\
\hline 697 & 8.3 \\
\hline 820.4 & 9.5 \\
\hline
\end{tabular}

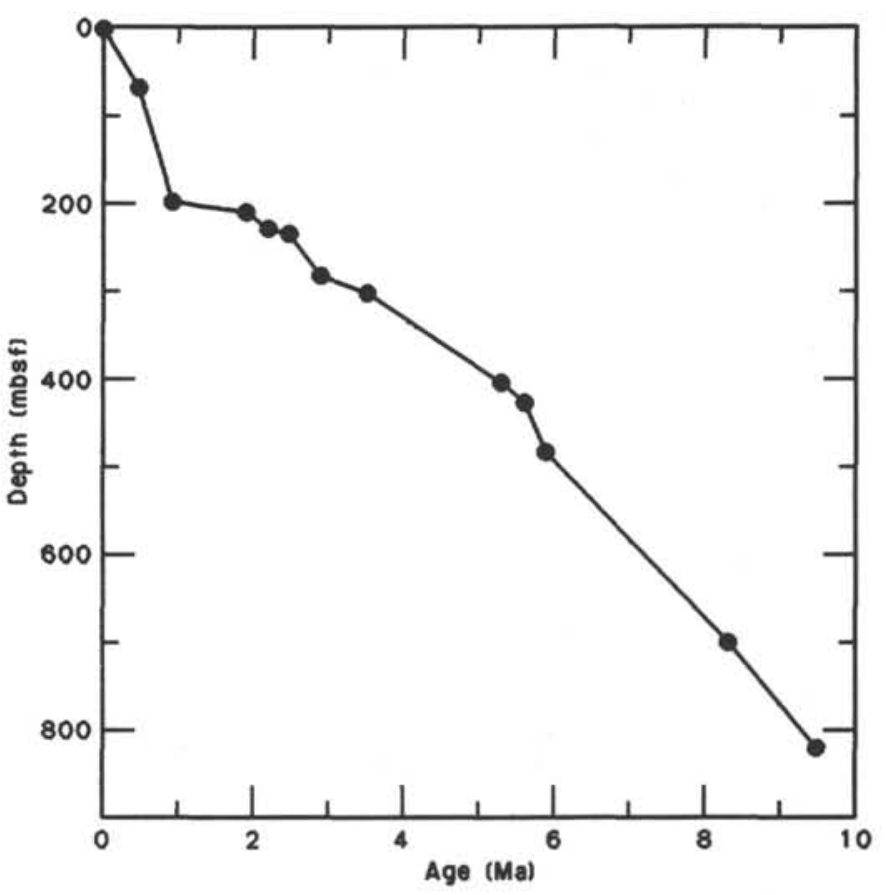

Figure 7. Sediment accumulation rate, Site 717 (not corrected for compaction).

19X (142 mbsf) and 116-717C-20X (154 mbsf) and were analyzed. The $C_{1}$ concentrations are $84.7 \%$ and $34.1 \%$, respectively. The presence of those gases can be explained in terms of the sulfate reduction-methane generation model (Claypool and Kaplan, 1974). In this model, the generation of $C_{1}$ is a result of the complete removal of sulfate by sulfate-reduction bacteria in the presence of sufficient organic material. At this site, the sulfate concentration decreases quickly to a few millimoles by Core 116-717C-4X. $\mathrm{C}_{2}$ concentrations show 75 and $3.1 \mathrm{ppm}$, respectively, in the two samples, but $\mathrm{C}_{3}$ was not found. Values for the $\mathrm{C}_{1} / \mathrm{C}_{2}$ ratio of vacutainer samples are high, about $1 \times 10^{5}$. It appears that the gases result from microbiological generation.

\section{Extracted Gases}

Whole pieces of sediment (approx. 3 to $5 \mathrm{~cm}$ in length) were sealed in headspace vials and maintained at $70^{\circ} \mathrm{C}$ for a minimum of $1.5 \mathrm{hr}$. Volumes $(0.25 \mathrm{~mL})$ of headspace gas were then analyzed on the HP Natural Gas Analyser system.

The $C_{1}$ content of the sediment ranges between 10 and 20 ppm down to Core $116-717 \mathrm{C}-4 \mathrm{X}$ and increases rapidly below Core 116-717C-5X (38 mbsf) (Fig. 8). The rapid increase in $C_{1}$ concentration at Core $116-717 \mathrm{C}-5 \mathrm{X}(38 \mathrm{mbsf})$ correlates inversely with a rapid decrease in sulfate concentration. The $\mathrm{C}_{1}$ concentration is mostly in the range 2000 to $7000 \mathrm{ppm}$ between depths of 30 and 250 mbsf but then drops to within the range 30 and $2000 \mathrm{ppm}$ from there to Core 116-717C-51X (450 mbsf) except for Core 116-717C-38X (326 mbsf). However, at a depth of 480 mbsf (Core 116-717-54X), the concentration increases abruptly to $5000 \mathrm{ppm}$. Below Core $116-717 \mathrm{C}-54 \mathrm{X}$, the $\mathrm{C}_{1}$ concentration again decreases slowly with depth to the bottom core (825 mbsf) (Table 5 and Fig. 8).

The decrease in $\mathrm{C}_{1}$ content with depth is sharp above Core 116-717C-49X, but more gradual below Core 116-717-54X. This difference suggests a difference of origin or source of organic materials. However, the consistently low concentrations of $\mathrm{C}_{2}$ throughout the section at Site $717 \mathrm{C}$ does not indicate any change in source. 
Table 4. Vacutainer gases, Site 717.

\begin{tabular}{lcccc}
\hline $\begin{array}{c}\text { Sample } \\
\text { (interval, cm) }\end{array}$ & $\begin{array}{c}\text { Depth } \\
\text { (mbsf) }\end{array}$ & $\begin{array}{c}\mathrm{C}_{1} \\
(\%)\end{array}$ & $\begin{array}{c}\mathrm{C}_{2} \\
(\mathrm{ppm})\end{array}$ & $\mathrm{C}_{1} / \mathrm{C}_{2}$ \\
\hline $717 \mathrm{C}-19 \mathrm{X}-1$ (103-108) & 142 & 84.7 & 7.5 & $1.1 \times 10^{6}$ \\
$717 \mathrm{C}-20 \mathrm{X}-3(80-85)$ & 154 & 34.1 & 3.1 & $1.1 \times 10^{6}$ \\
\hline
\end{tabular}

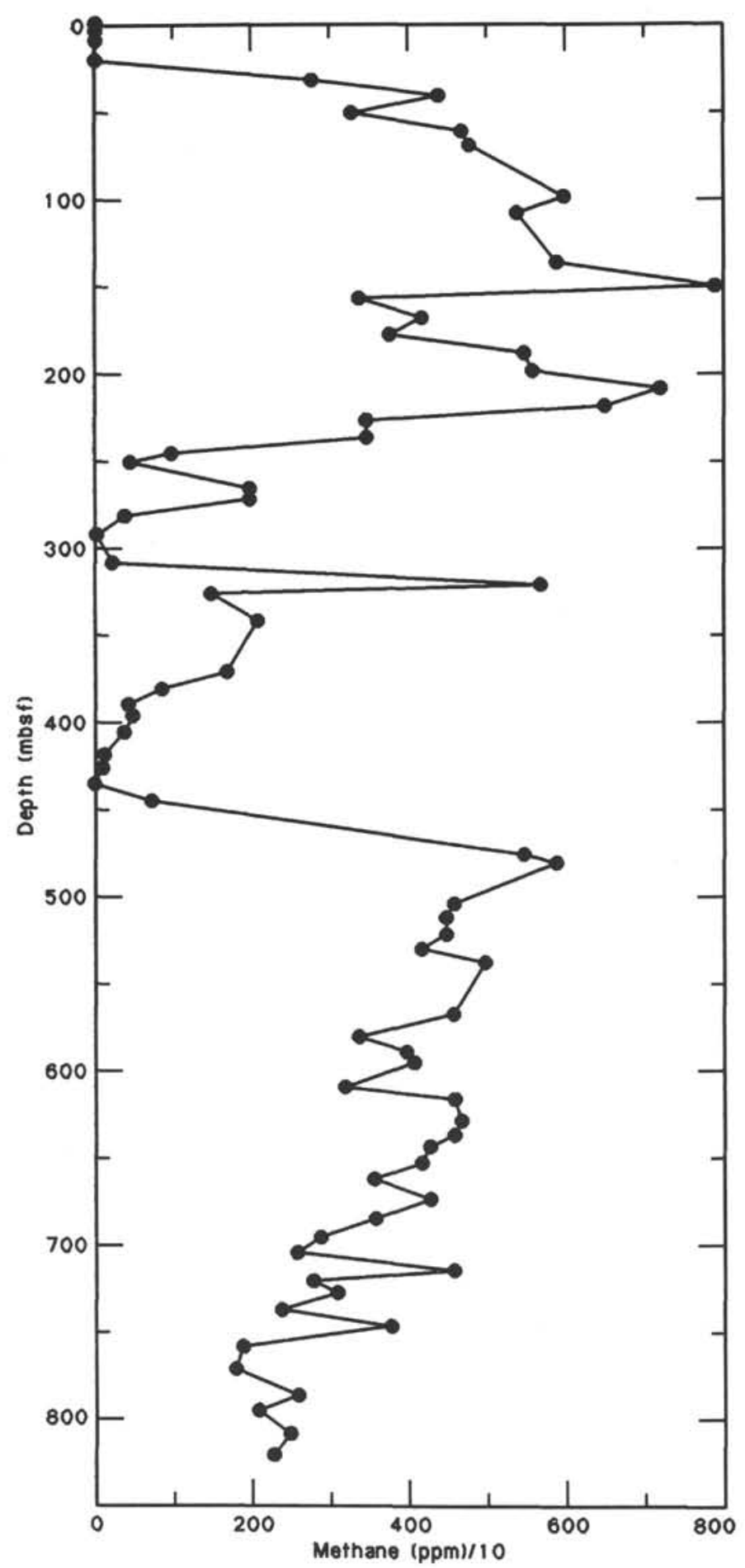

Figure 8. Extracted methane concentrations vs. depth, determined by the headspace procedure at Hole $717 \mathrm{C}$.

\section{Carbon}

A portion of each of 73 sediment samples above the depth of 822 mbsf was analyzed for total carbon, carbonate carbon, and organic carbon. The results are given in Table 6 and displayed in Figure 9. These results indicate less than $4.60 \%$ carbonate carbon (see "Lithostratigraphy" section, this chapter). Organic carbon values are high (greater than $7 \%$ in one sample at a depth of $102.8 \mathrm{mbsf}$ ). The large amount of organic material stimulated bacterial activity that generated the vacutainer gases (Table 4). The organic carbon concentration is an average of about $1.0 \%$ above a depth of 500 mbsf and less than $0.5 \%$ below $500 \mathrm{mbsf}$. In the lower section there is little variation, indicating a low uniform input of organic carbon in turbidity currents and/or rapid consumption by bacterial action. In the upper section, there appears to be a cyclic alternation, typically between about $0.1 \%$ and $2.5 \%$ organic carbon. This averages approximately the same weight as that found beneath the high productivity zone in the Arabian Sea (i.e., about 1\%). But primary production shows $150-250 \mathrm{mg} \mathrm{C} / \mathrm{m}^{3} \times$ day in the Bay of Bengal, which is less than half that in the Arabian Sea $\left(500 \mathrm{mg} \mathrm{C} / \mathrm{m}^{3} \times\right.$ day) (Degens and Mopper, 1976). Clearly, much of the large volume of organic material is terrestrial and ultimately derived from the Ganges and Brahmaputra rivers.

\section{Rock-Eval}

Rock-Eval results are given in Table 7. The Hydrogen Index (HI) and Oxygen Index (OI) values fall in the field for Type III (terrestrial wood) when they are plotted on a van Krevelen-like diagram (Tissot and Welte, 1984) (Fig. 10). These results suggest that all of the carbon is derived from terrestial sources, which would be consistent with an origin from plants growing on the Ganges-Brahmaputra river/delta plain. In the data, the primary productivity in this area was not high because Type II (marine origin) does not exist. $\mathrm{T}_{\max }$ values range from 380 to $440^{\circ} \mathrm{C}$, which indicate that the organic matter is immature with respect to petroleum potential.

\section{INORGANIC GEOCHEMISTRY}

\section{Methods}

Methods employed for interstitial water (IW) studies are those described in Gieskes and Peretsman (1986). When the amount of IW collected was too low to allow regular shipboard analyses, we measured alkalinity on $1 \mathrm{~cm}^{3}$ rather than $5 \mathrm{~cm}^{3}$ and $\mathrm{pH}$ on the volume of sample left after shipboard analyses. In this case the uncertainty of the $\mathrm{pH}$ measurements was about 0.05 $\mathrm{pHu}$. Separate titration analyses were made for $\mathrm{Mg}, \mathrm{Ca}, \mathrm{Cl}$, $\mathrm{SO}_{4}, \mathrm{PO}_{4}, \mathrm{NO}_{3}, \mathrm{NH}_{4}, \mathrm{Si}$, and total salinity. Other analyses that will be carried out in shore-based laboratory include $\mathrm{K}, \mathrm{Sr},{ }^{87} \mathrm{Sr}$ / ${ }^{86} \mathrm{Sr}$, trace metals, ${ }^{18} \mathrm{O} /{ }^{16} \mathrm{O}$, and $\mathrm{D} / \mathrm{H}$. A check for methane concentrations that should favor hydrate formation and decrease chlorinity was carried out following Blanc et al. (1986).

\section{Results}

The results of shipboard measurements of interstitial water composition are given in Table 8, in Figures 11 through 18, and as discussed below.

\section{Chloride (Cl) and Sodium plus Potassium $(\mathrm{Na}+\mathrm{K})$}

The concentrations of $\mathrm{Cl}$ as well as $\mathrm{Na}+\mathrm{K}$ show very large variation, ranging over almost $20 \%$. Such scatter in biogenic sediments is not uncommon (Sayles and Manheim, 1975) but has rarely been observed in terrigenous sediments. Possible pollution by the different drill fluids was investigated as a cause, 
Table 5. Headspace gases at Site 717 .

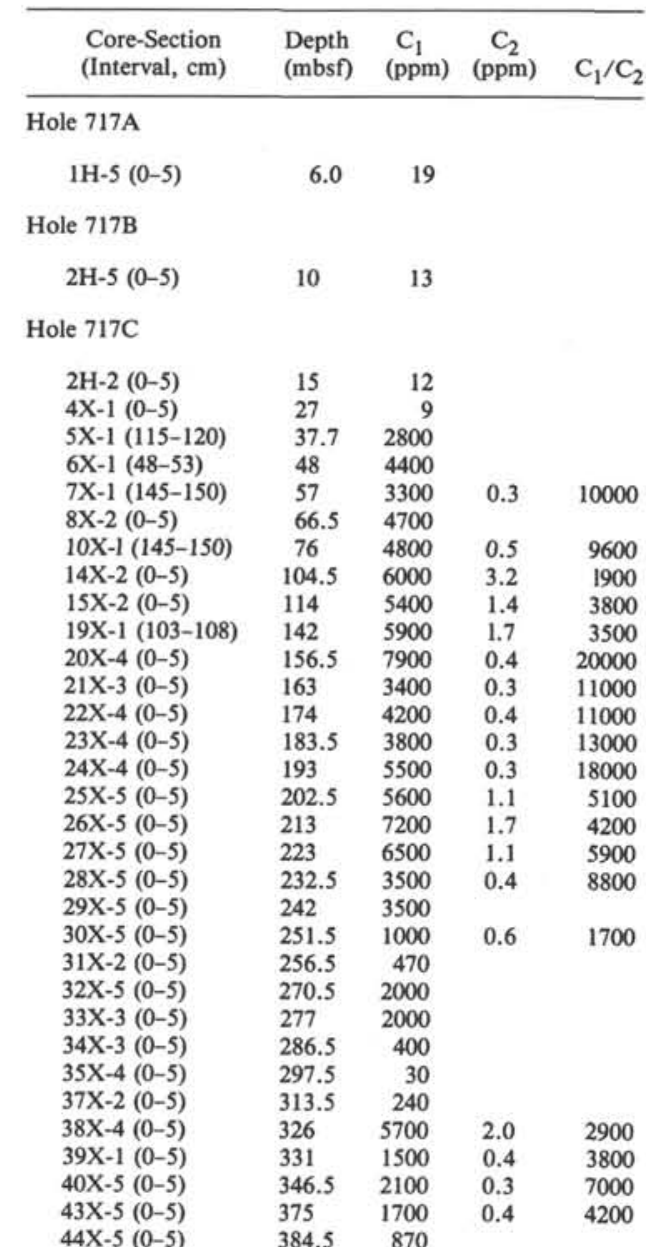

but no evidence in its favor was found. Figures 11 and 12 present two different trends of these elements with depth:

1. The low $\mathrm{Cl}$ and $\mathrm{Na}+\mathrm{K}$ values correspond to clay-rich sediment (dashed curve).

2. The high $\mathrm{Cl}$ and $\mathrm{Na}+\mathrm{K}$ values correspond to sand-type sediments (dash-dot curve).

The $(\mathrm{Na}+\mathrm{K}) / \mathrm{Cl}$ ratios were always lower than bottom seawater except for the last sample collected at a depth of $823 \mathrm{~m}$. The interpretation of these trends is not yet clear, although it may reflect early diagenetic changes in different clay minerals.

These results may be attributed to:

1. Low values: expulsion of water from smectite-type minerals resulting from continental weathering, and replacement of $\mathrm{Ca}$ by $\mathrm{K}$ and $\mathrm{Mg}$ in interstitial sheet position;

2. High values: clay diagenesis in sandstone-type sediment. It is accompanied by uptake of water for the hydrolysis and hydration sphere of metals in interstitial sheet position.

\section{Calcium (Ca)}

In the upper $250 \mathrm{~m}, \mathrm{Ca}$ values are lower than in bottom seawater with a small increase between 60 and 100 mbsf superimposed on the general trend (Fig. 13). From 250 to $500 \mathrm{mbsf} \mathrm{Ca}$ increases; from 500 to 800 mbsf the value is almost level, with a small step increase near 700-723 mbsf. There is an abrupt increase in the lowest sample ( $823 \mathrm{mbsf})$.
Table 5 (continued).

\begin{tabular}{|c|c|c|c|c|}
\hline $\begin{array}{l}\text { Core-Section } \\
\text { (Interval, cm) }\end{array}$ & $\begin{array}{l}\text { Depth } \\
\text { (mbsf) }\end{array}$ & $\begin{array}{c}\mathrm{C}_{1} \\
(\mathrm{ppm})\end{array}$ & $\underset{(\mathrm{ppm})}{\mathrm{C}_{2}}$ & $C_{1} / C_{2}$ \\
\hline $45 X-5(0-5)$ & 394 & 440 & & \\
\hline $46 X-3(0-5)$ & 400.5 & 500 & & \\
\hline $47 X-3(0-5)$ & 410 & 390 & & \\
\hline $48 X-5(0-5)$ & 422.5 & 130 & & \\
\hline $49 X-4(0-5)$ & 430.5 & 100 & 0.5 & 2000 \\
\hline $50 \times-4(0-5)$ & 440 & - & & \\
\hline $51 X-4(0-5)$ & 449.5 & 730 & & \\
\hline $54 X-5(0-5)$ & 479.5 & 5500 & 3.2 & 1700 \\
\hline $55 X-2(0-5)$ & 484.5 & 5900 & 4.3 & 1500 \\
\hline $57 X-5(0-5)$ & 508 & 4600 & 1.6 & 2900 \\
\hline $58 X-4(0-5)$ & 516 & 4500 & 2.0 & 2300 \\
\hline $59 X-4(0-5)$ & 525.5 & 4500 & 1.8 & 2500 \\
\hline $60 X-3(0-5)$ & 533.5 & 4200 & 0.4 & 11000 \\
\hline $61 X-2(0-5)$ & 541.5 & 5000 & 2.0 & 2500 \\
\hline $64 X-3(0-5)$ & 571.5 & 4600 & 1.9 & 2400 \\
\hline $65 X-5(0-5)$ & 584 & 3400 & 0.7 & 4900 \\
\hline $66 \times-4(0-5)$ & 592 & 4000 & 0.8 & 5000 \\
\hline $67 X-2(0-5)$ & 598.5 & 4100 & 1.6 & 2600 \\
\hline $68 X-5(0-5)$ & 612.5 & 3200 & 1.2 & 2600 \\
\hline $69 X-3(0-5)$ & 619 & 4600 & 2.2 & 2100 \\
\hline $70 X-5(0-5)$ & 631.5 & 4700 & 1.6 & 2900 \\
\hline $71 X-4(0-5)$ & 639.5 & 4600 & 3.2 & 1400 \\
\hline $72 X-2(0-5)$ & 646 & 4300 & 1.9 & 2300 \\
\hline $73 X-2(0-5)$ & 655.5 & 4200 & 3.0 & 1400 \\
\hline $74 X-2(0-5)$ & 665 & 3600 & 1.3 & 2800 \\
\hline $75 X-3(0-5)$ & 676 & 4300 & 3.7 & 1200 \\
\hline $76 X-4(0-5)$ & 687 & 3600 & 2.9 & 1200 \\
\hline $77 X-5(0-5)$ & 698 & 2900 & 1.1 & 2600 \\
\hline $78 X-5(0-5)$ & 707.5 & 2600 & 1.4 & 1800 \\
\hline $79 X-5(0-5)$ & 717 & 4600 & 2.2 & 2100 \\
\hline $80 X-3(0-5)$ & 723.5 & 2800 & 1.4 & 2000 \\
\hline $81 X-1(0-5)$ & 730 & 3100 & 0.4 & 7700 \\
\hline $82 X-1(0-5)$ & 739.5 & 2400 & 1.2 & 2000 \\
\hline $83 X-1(0-5)$ & 749 & 3800 & 2.2 & 1700 \\
\hline $84 X-3(0-5)$ & 761.5 & 1900 & 0.8 & 2400 \\
\hline $85 X-5(0-5)$ & 774 & 1800 & 2.5 & 7100 \\
\hline $87 X-2(0-5)$ & 788.5 & 2600 & 3.7 & 700 \\
\hline $88 X-1(97-102)$ & 797.5 & 2100 & 4.9 & 400 \\
\hline $90 X-1(145-150)$ & 810.6 & 2500 & 3.7 & 660 \\
\hline $91 X-3(125-130)$ & 825 & 2300 & 1.2 & 1900 \\
\hline
\end{tabular}

The upper part corresponds to the precipitation of calcite and/or high magnesium carbonate. From 250 mbsf downward the exchange of $\mathrm{Ca}$ by other cations in clay minerals is the main controlling factor of $\mathrm{Ca}$ in IW. The offset of $\mathrm{Ca}$ near 60 to 130 mbsf could correspond to dolomite replacement of calcite, which is possible as sulfate has almost been completely reduced at this depth range. This explanation was also suggested by a large decrease of the IW Mg content at the same depth.

\section{Magnesium (Mg)}

The general trend of $\mathrm{Mg}$ vs. depth was toward lower values (dashed line, Fig. 14). This can be explained by $\mathrm{Mg}$ replacing $\mathrm{Ca}$ in clay minerals. This behavior of $\mathrm{Ca}$ and $\mathrm{Mg}$ is one of the main characteristic features found in numerous IW measurements in previous DSDP and ODP legs. However, there was a large scatter of values for $\mathrm{Mg}$. Some of this scatter could be a result of deposition of high $\mathrm{Mg}$ carbonates or dolomite $(60-130,510$ mbsf).

\section{Alkalinity (Alk.) Calcium Carbonate Saturation}

The general trend of Alk. vs. depth was toward lower values (dashed line, Fig. 15). A large scatter occurred in the upper $300 \mathrm{~m}$. Between 70 and $230 \mathrm{mbsf}$ Alk. variations were correlated with those of $\mathrm{Mg}$ and hence are opposed to those of $\mathrm{Ca}$. This is a reflection of the IW-carbonate chemistry already mentioned.

This characteristic can be checked with the Ion Activity Product (I.A.P.) of calcium carbonate vs. depth as shown in Figure 16. In this graph no correction for borate content of alkalinity 
Table 6. Organic carbon and carbonate carbon, Site 717.

\begin{tabular}{|c|c|c|c|}
\hline $\begin{array}{l}\text { Core section } \\
\text { (Interval, cm) }\end{array}$ & $\begin{array}{l}\text { Depth } \\
\text { (mbsf) }\end{array}$ & $\begin{array}{c}\text { Inorganic } \\
\text { carbon } \\
(\%)\end{array}$ & $\begin{array}{c}\text { Organic } \\
\text { carbon } \\
(\%)\end{array}$ \\
\hline \multicolumn{4}{|l|}{ Hole 717A } \\
\hline $1 \mathrm{H}-4(60-65)$ & 5.1 & 0.64 & 0.56 \\
\hline $2 \mathrm{H}-2(80-82)$ & 6.3 & 0.41 & 0.05 \\
\hline \multicolumn{4}{|l|}{ Hole 717B } \\
\hline $2 \mathrm{H}-6(113-115)$ & 12.7 & 0.58 & 0.39 \\
\hline \multicolumn{4}{|l|}{ Hole $717 \mathrm{C}$} \\
\hline $2 \mathrm{H}-2(113-118)$ & 6.7 & 0.60 & 1.81 \\
\hline $4 X-2(60-65)$ & 29.1 & 0.45 & 1.36 \\
\hline $5 X-1(110-113)$ & 37.6 & 0.53 & 0.26 \\
\hline $6 \mathrm{X}-1(113-118)$ & 47.1 & 0.39 & 1.07 \\
\hline $7 X-2(2-4)$ & 57.0 & 0.50 & 0.07 \\
\hline $8 X-2(64-69)$ & 67.1 & 2.77 & 1.48 \\
\hline $14 X-2(19-22)$ & 104.7 & 0.48 & 0.62 \\
\hline $16 X-1(72-77)$ & 122.7 & 0.39 & 0.66 \\
\hline $19 X-1(86-89)$ & 141.9 & 0.73 & 0.76 \\
\hline $20 X-2(89-93)$ & 152.9 & 0.68 & 0.58 \\
\hline $21 X-4(66-70)$ & 165.2 & 0.28 & 2.12 \\
\hline $22 X-4(84-89)$ & 174.9 & 0.27 & 7.36 \\
\hline $23 X-6(60-65)$ & 187.1 & 0.47 & 1.59 \\
\hline $24 X-7(60-65)$ & 196.6 & 0.12 & 2.05 \\
\hline $25 X-6(60-64)$ & 206.1 & 0.14 & 1.99 \\
\hline $26 X-7(10-14)$ & 216.6 & 0.40 & 1.73 \\
\hline $27 X-4(65-68)$ & 225.2 & 0.04 & 0.35 \\
\hline $28 \times-4(63-67)$ & 231.6 & 0.14 & 1.19 \\
\hline $29 X-4(62-65)$ & 241.0 & 0.03 & 1.66 \\
\hline $30 X-6(63-67)$ & 253.5 & 0.36 & 2.08 \\
\hline $31 X-3(20-24)$ & 258 & 0.51 & 1.84 \\
\hline $32 X-1(117-121)$ & 267 & 0.39 & 0.61 \\
\hline $33 X-6(60-66)$ & 282 & 0.43 & 0.46 \\
\hline $34 X-2(90-94)$ & 286 & 4.63 & 1.21 \\
\hline $35 X-6(60-64)$ & 306 & 0.57 & 1.66 \\
\hline $36 \times-4(60-64)$ & 316 & 1.09 & 0.54 \\
\hline $37 X-3(73-76)$ & 318 & 0.42 & 0.44 \\
\hline $38 X-2(88-90)$ & 324 & 0.60 & 0.44 \\
\hline $39 X-1(38-41)$ & 331 & 0.74 & 0.65 \\
\hline $40 \times-6(47-50)$ & 348.5 & 0.32 & 2.04 \\
\hline $42 X-6(104-107)$ & 368 & 0.31 & 1.58 \\
\hline $43 X-4(0-150)$ & 373.5 & 0.53 & 1.71 \\
\hline
\end{tabular}

was done, so the data are displaced by a factor with respect to the true I.A.P. and hence with respect to the solubility product. One can see that most of the samples collected below $300 \mathrm{mbsf}$ can be considered at equilibrium with calcite.

The last sample shows a large increase of Alk. and I.A.P., which was quite unexpected at $823 \mathrm{mbsf}$. Upon sampling, a strong odor of polyalkylamine was noted in the same depth range. This could be a result of the extensive fermentation of organic matter, mostly from siliceous-type plankton. The resulting content of organic matter in the corresponding sediment was low $(0.2 \%)$ as compared with the remainder of the core, and no siliceous tests were observed at this depth. The formation of an indurated sandstone layer, with visible carbonate veins near $790 \mathrm{mbsf}$, may be related to this large alkalinity increase following degradation of organic matter.

\section{Sulfate $\left(\mathrm{SO}_{4}\right)$}

As expected in organic-rich pelagic and terrigenous mud, $\mathrm{SO}_{4}$ showed a strong decrease in the first $25 \mathrm{~m}$. Below $150 \mathrm{mbsf}$, the values was scattered around 2 to $3 \mathrm{mmol}$. This scatter can be partly attributed to oxidation of pyrite during the various sampling operations. Between 50 and $100 \mathrm{mbsf}$ there was a small increase in $\mathrm{SO}_{4}$ following the offset of $\mathrm{Ca}$. This could be the result of release of residual $\mathrm{SO}_{4}$ from the surface of calcite upon its transformation into dolomite as already noted.
Table 6 (continued).

\begin{tabular}{|c|c|c|c|}
\hline $\begin{array}{l}\text { Core section } \\
\text { (Interval, cm) }\end{array}$ & $\begin{array}{l}\text { Depth } \\
\text { (mbsf) }\end{array}$ & $\begin{array}{c}\text { Inorganic } \\
\text { carbon } \\
(\%)\end{array}$ & $\begin{array}{c}\text { Organic } \\
\text { carbon } \\
(\%)\end{array}$ \\
\hline $43 X-5(0-150)$ & 375 & 0.24 & 1.93 \\
\hline $46 X-4(59-61)$ & 402.5 & 0.15 & 1.93 \\
\hline $47 X-2(60-62)$ & 409 & 0.53 & 1.70 \\
\hline $48 X-6(41-46)$ & 424.5 & 0.53 & 0.44 \\
\hline $49 X-4(63-64)$ & 431 & 0.67 & 2.05 \\
\hline $50 X-6(26-28)$ & 443 & 0.82 & 0.78 \\
\hline $51 X-4(41-42)$ & 450 & 0.75 & 0.72 \\
\hline $52 X-2(134-139)$ & 457.3 & 1.17 & 0.30 \\
\hline $53 X-6(120-122)$ & 474 & 3.21 & 1.39 \\
\hline $54 X-6(142-144)$ & 482.5 & 0.18 & 0.43 \\
\hline $55 X-2(73-75)$ & 485 & 0.41 & 2.27 \\
\hline $56 \mathrm{X}-6(126-129)$ & 501.2 & 0.59 & 0.79 \\
\hline $59 X-6(139-144)$ & 520.4 & 1.81 & 0.14 \\
\hline $60 X-2(62-66)$ & 532.6 & 0.55 & 0.18 \\
\hline $61 X-2(128-132)$ & 540.8 & 1.27 & 0.31 \\
\hline $63 X-2(50-53)$ & 561 & 0.69 & 0.46 \\
\hline $64 X-2(38-42)$ & 570.4 & 3.19 & 0.64 \\
\hline $65 X-6(21-23)$ & 585.7 & 0.06 & 0.32 \\
\hline $66 \mathrm{X}-3(21-23)$ & 591.3 & 0.72 & 0.42 \\
\hline $67 X-2(120-122)$ & 599.7 & 1.02 & 0.35 \\
\hline $68 X-5(70-72)$ & 611.2 & 1.09 & 0.27 \\
\hline $69 X-2(33-36)$ & 617.8 & 1.25 & 0.29 \\
\hline $70 X-6(70-72)$ & 633.7 & 0.74 & 0.33 \\
\hline $71 \mathrm{X}-\mathrm{CC}(14-16)$ & 644.2 & 1.31 & 0.32 \\
\hline $72 X-2(84-86)$ & 646.8 & 1.15 & 0.25 \\
\hline $73 X-2(61-63)$ & 656 & 1.29 & 0.26 \\
\hline $75 X-4(65-70)$ & 678 & 0.84 & 0.40 \\
\hline $76 X-6(46-51)$ & 690.5 & 0.93 & 0.32 \\
\hline $77 X-6(40-44)$ & 700 & 4.64 & 0.85 \\
\hline $78 \times-6(143-146)$ & 710.5 & 1.19 & 0.40 \\
\hline $79 X-6(24-26)$ & 718.8 & 0.94 & 0.41 \\
\hline $80 X-3(105-108)$ & 824.5 & 1.09 & 0.36 \\
\hline $83 X-1(65-69)$ & 749.7 & 1.48 & 0.22 \\
\hline $84 \mathrm{X}-\mathrm{CC}(11-13)$ & 767.6 & 1.17 & 0.34 \\
\hline $85 X-5(123-125)$ & 775.2 & 1.31 & 0.46 \\
\hline $87 X-2(87-91)$ & 789.4 & 0.11 & 0.17 \\
\hline $90 \times-1(35-39)$ & 809.5 & 0.89 & 0.31 \\
\hline $91 X-3(38-40)$ & 822 & 0.53 & 0.18 \\
\hline
\end{tabular}

Punch-in tests for the presence of free hydrogen sulfide were done by inserting a specific electrode in the sediment. The results were always negative. This can be attributed to the formation of iron sulfides $\left(\mathrm{FeS}_{2}, \mathrm{Fe}_{3} \mathrm{~S}_{4}\right)$ owing to the release of iron from terrigenous clays or oxides and reaction with $\mathrm{H}_{2} \mathrm{~S} / \mathrm{HS}$. The presence of these sulfides was often noted in the sediment.

\section{Silica $\left(\mathrm{SiO}_{2}\right)$}

$\mathrm{SiO}_{2}$ has moderate concentrations in IW at most depths except near 150-250 mbsf and at the bottom of the core near 823 mbsf. This low level is indicative of the low concentration of biogenic silica. The peak near 200 mbsf corresponded to a layer where radiolarians were preserved because of an iron sulfide coating. Note that the width of the peak is about $200 \mathrm{~m}$. This corresponds to a diffusive path length with a time scale about $1 \mathrm{Ma}$, which is also the age attributed to this layer. The high in $\mathrm{SiO}_{2}$ around 200 mbsf may be caused mainly by one source layer rich in decomposing siliceous tests.

There was also a very large increase of $\mathrm{SiO}_{2}$ at $823 \mathrm{mbsf}$. This corresponds to the large Alk. and $\mathrm{Ca}$ increases. Increased $\mathrm{SiO}_{2}$ may be attributed to fermentation of siliceous plankton. However, no siliceous test was observed at this depth, casting some doubt on the diagenetic origin for the Ca-Alk.- $\mathrm{SiO}_{2}$ increases.

\section{Phosphate $\left(\mathrm{PO}_{4}\right)$, Ammonia $\left(\mathrm{NH}_{4}\right)$, and Nitrate $\left(\mathrm{NO}_{3}\right)$}

$\mathrm{PO}_{4}$ concentrations in IW were significant in the upper 250 $\mathrm{m}$. In the deeper parts, they were low. The peak at $150 \mathrm{mbsf}$ correlated well with Alk. Hence, this zone can effectively be the source of Alk. and $\mathrm{PO}_{4}$. 


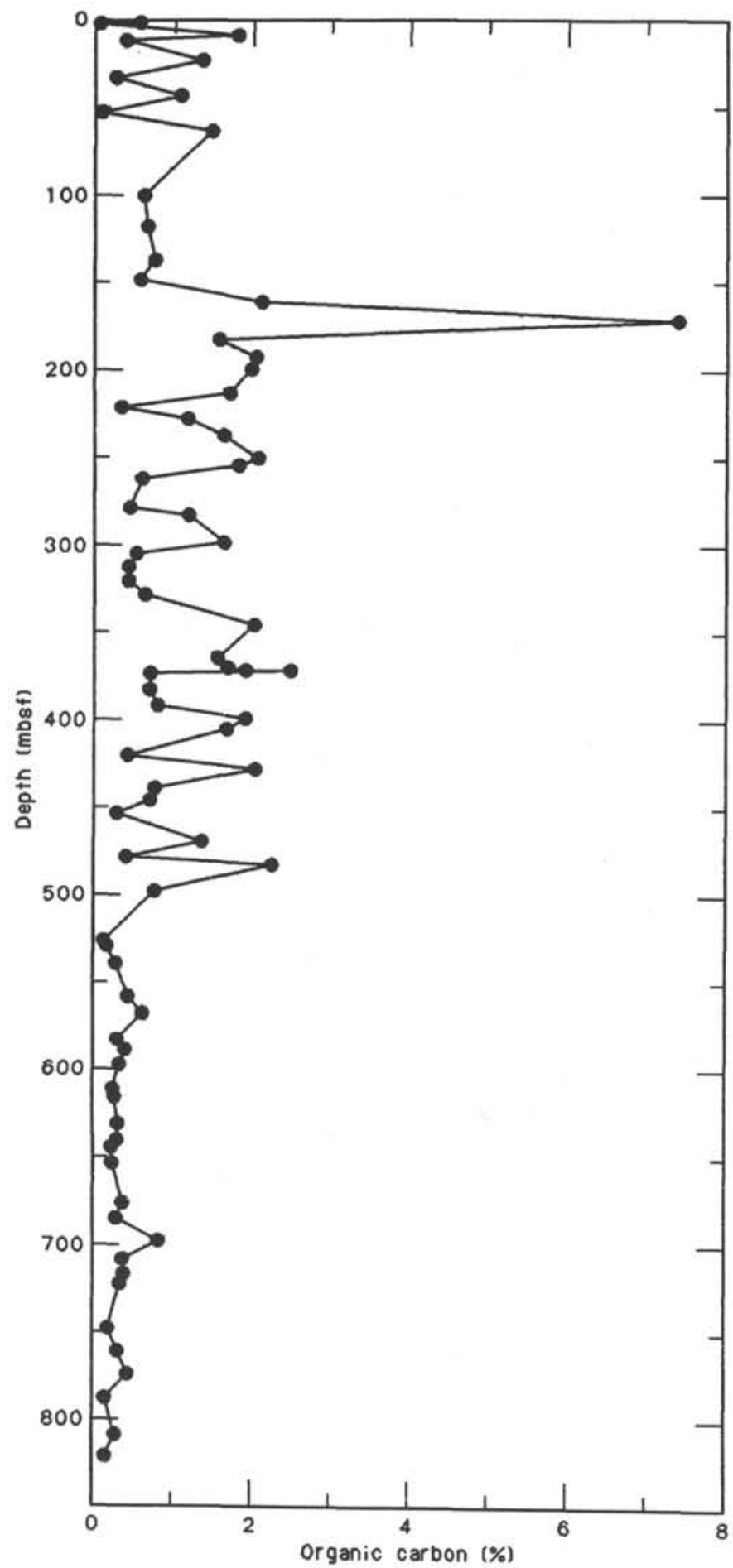

Figure 9. Organic carbon concentrations vs. depth at Hole 717C.

$\mathrm{PO}_{4}$ and $\mathrm{NH}_{4}$ concentrations at 823 mbsf were very low, which does not favor the attribution of increases of Ca-Alk.$\mathrm{SiO}_{2}$ to organic fermentation, as based on the sole Alk. result.

$\mathrm{NH}_{4}$ was in the normal range found for the type of sediment encountered at Site 717. The maximum value near $150 \mathrm{mbsf}$ is in good correlation with Alk. and $\mathrm{PO}_{4}$.

The $\mathrm{NO}_{3}$ measurements were done only in the upper $350 \mathrm{~m}$. They yielded essentially zero, which they should when sulfate reduction has occurred. The value at 150 mbsf was most probably due to oxidation of $\mathrm{NH}_{4}$.

\section{Discussion}

Most of the results obtained are quite clear but will have to wait for the shore-based laboratory analyses before more extensive discussion of the first conclusions is possible. In the following only the implications of the large anomalies found at 823 mbsf are discussed.

The large anomalies for Alk., $\mathrm{SiO}_{2}$, and $\mathrm{Ca}$ at first suggest they are from extensive diagenesis of organic matter; however, several contrary observations refute this interpretation. First is the lack of siliceous and carbonate tests and the low total organic carbon content, second is the lack of an increase of $\mathrm{NH}_{4}$ and $\mathrm{PO}_{4}$ as observed elsewhere in the same core, where extensive organic diagenesis is occuring.

The anomalies of Alk., $\mathrm{SiO}_{2}$, and $\mathrm{Ca}$ could be associated with lateral circulation of a fluid that has acquired these characteristics elsewhere. Vertical circulation from 823 to $790 \mathrm{mbsf}$ must be limited or the vertical gradient would be much smoother than observed. The zone between 823 and 790 mbsf may therefore be the location of, at least, a local barrier for vertical circulation and diffusion.

An interpretation of some of the characteristics of the IW collected at $823 \mathrm{mbsf}$ is that it originates from a place at higher temperature and that it has retained some properties acquired by higher temperature water-rock interactions, i.e., increase in $\mathrm{Ca}$, decrease in $\mathrm{Mg}$, and perhaps increase in $\mathrm{Na}+\mathrm{K}$. In this case the $\mathrm{SiO}_{2}$ anomaly corresponds to near equilibrium with amorphous silica at the temperature/pressure conditions at $823 \mathrm{mbsf}$ and the Alk. anomaly corresponds to more extensive rock alteration at higher temperature. This interpretation implies convective-type fluid circulation in the vicinity of Site 717.

\section{Conclusions}

The IW samples collected at Site 717 show the following characteristics:

1. Clear differentiation between clay and sandstone sediments;

2. Clay sediments show a decrease of $\mathrm{Cl}$ and $\mathrm{Na}+\mathrm{K}$ perhaps attributable to expulsion of interstitial water from sheets of smectite-type minerals;

3. Sandstones show an increase of $\mathrm{Cl}$ and $\mathrm{Na}+\mathrm{K}$ attributed to the uptake of water in the interlayer position of clay minerals;

4. Clay minerals from terrestrial sources exchange $\mathrm{Ca}$ and $\mathrm{Mg}$, thus leading to a decrease of $\mathrm{Mg}$ and an increase of $\mathrm{Ca}$ in IW;

5. Calcium carbonate and/or high $\mathrm{Mg}$ carbonate should precipitate at different depths, $0-30,150-250$, and $510 \mathrm{mbsf}$; dolomite may precipitate at $60-130 \mathrm{mbsf}$;

6. At depths deeper than about 800 mbsf there should be a lateral circulation of IW with limited vertical movement upward above 790 mbsf; this fluid may be part of a convective system.

\section{PALEOMAGNETISM}

Major precruise objectives for paleomagnetic work at this site were a magnetostratigraphic study of the late Miocene through Holocene sediments and a careful examination of various geomagnetic phenomena including field excursions and polarity transitions. The expected high sedimentation rate in this region and the anticipated completeness of the sedimentary section promised ideal conditions to study the fine structure of the geomagnetic field over the past $10 \mathrm{Ma}$. Such studies, however, require oriented and relatively undisturbed core material. As described below, these conditions were not attained at this site and consequently little information regarding the behavior of the geomagnetic field could be obtained. However, interesting magnetic in- 
Table 7. Rock-Eval summary, Site 717.

\begin{tabular}{|c|c|c|c|c|c|c|c|c|}
\hline $\begin{array}{l}\text { Core Section } \\
\text { (interval, cm) }\end{array}$ & $\begin{array}{l}\text { Depth } \\
\text { (mbsf) }\end{array}$ & $\mathrm{T}_{\max }$ & $\mathrm{S}_{1}$ & $\mathrm{~S}_{2}$ & $\mathrm{~S}_{3}$ & TOC & HI & OI \\
\hline \multicolumn{9}{|l|}{ Hole 717A } \\
\hline $1 \mathrm{H}-4(60-65)$ & 5.1 & 427 & 0.10 & 0.74 & 2.58 & 0.56 & 130 & 460 \\
\hline $2 \mathrm{H}-2(113-118)$ & 6.7 & 427 & 0.18 & 0.77 & 2.58 & 1.81 & 41 & 143 \\
\hline \multicolumn{9}{|l|}{ Hole 717B } \\
\hline $2 \mathrm{H}-6(113-118)$ & 12.7 & 440 & 0.08 & 0.32 & 1.21 & .39 & 82 & 310 \\
\hline \multicolumn{9}{|l|}{ Hole $717 \mathrm{C}$} \\
\hline $2 \mathrm{H}-2(80-82)$ & 6.3 & 435 & 0.28 & 0.44 & 2.33 & 0.05 & 880 & 4660 \\
\hline $4 \mathrm{X}-2(60-65)$ & 29.1 & 481 & 0.24 & 1.04 & 2.46 & 1.36 & 77 & 181 \\
\hline $5 X-1$ (110-113) & 37.6 & 402 & 0.04 & 0.21 & 0.46 & 0.26 & 81 & 177 \\
\hline $6 \mathrm{X}-1$ (113-118) & 47.1 & 386 & 0.06 & 0.14 & 1.51 & 1.07 & 13 & 141 \\
\hline $7 X-2(2-4)$ & 57.0 & 382 & 0.01 & 0.07 & 0.09 & 0.07 & 100 & 129 \\
\hline $19 \mathrm{X}-1(86-89)$ & 141.9 & 436 & 0.08 & 0.37 & 3.41 & 0.76 & 487 & 449 \\
\hline $20 \times-2$ (89-93) & 152.9 & 435 & 0.08 & 0.30 & 2.18 & 0.58 & 52 & 376 \\
\hline $21 X-4(66-70)$ & 165.2 & 440 & 0.08 & 0.32 & 1.21 & 2.12 & 15 & 55 \\
\hline $22 \mathrm{X}-4(84-89)$ & 174.9 & 435 & 0.28 & 0.44 & 2.33 & 7.36 & 6 & 32 \\
\hline $23 X-6(60-65)$ & 187.1 & 481 & 0.24 & 1.04 & 2.46 & 1.59 & 176 & 155 \\
\hline $24 X-6(60-65)$ & 196.6 & 402 & 0.04 & 0.21 & 0.46 & 2.05 & 10 & 22 \\
\hline $25 X-6(60-65)$ & 206.1 & 386 & 0.06 & 0.14 & 1.51 & 1.99 & 7 & 76 \\
\hline $26 X-7(10-14)$ & 216.6 & 382 & 0.01 & 0.07 & 0.19 & 1.73 & 4 & 11 \\
\hline $27 \mathrm{X}-6(65-68)$ & 225.2 & 436 & 0.08 & 0.37 & 3.41 & 0.35 & 106 & 974 \\
\hline $28 X-4(63-67)$ & 231.6 & 435 & 0.08 & 0.30 & 2.18 & 1.19 & 25 & 183 \\
\hline $29 \times-4(62-65)$ & 241 & 377 & 0.18 & 0.96 & 2.84 & 0.66 & 145 & 430 \\
\hline $30 \times-6(63-67)$ & 253.5 & 409 & 0.12 & 0.42 & 5.76 & 2.08 & 20 & 276 \\
\hline $31 X-3(20-24)$ & 258 & 396 & 0.08 & 0.28 & 5.56 & 1.84 & 15 & 302 \\
\hline $32 X-1(117-121)$ & 267 & 374 & 0.06 & 0.17 & 2.32 & 0.61 & 27 & 380 \\
\hline $33 X-6(60-66)$ & 282 & 377 & 0.03 & 0.00 & 2.00 & 0.46 & 0 & 434 \\
\hline $34 X-2$ (90-94) & 286 & 407 & 0.14 & 0.82 & 4.89 & 1.21 & 67 & 404 \\
\hline $35 X-6(60-64)$ & 306 & 406 & 0.08 & 0.28 & 5.20 & 1.66 & 16 & 313 \\
\hline $36 \mathrm{X}-4(60-64)$ & 316 & 377 & 0.07 & 0.07 & 2.55 & 0.54 & 12 & 472 \\
\hline $37 X-3(73-76)$ & 318 & 275 & 0.09 & 0.07 & 1.49 & 0.44 & 15 & 338 \\
\hline $38 X-2(88-90)$ & 324 & 242 & 0.03 & 0.00 & 2.64 & 0.44 & 0 & 600 \\
\hline $39 \mathrm{X}-1(38-41)$ & 331 & 317 & 0.03 & 0.06 & 2.20 & 0.65 & 9 & 338 \\
\hline $40 X-6(47-50)$ & 348.5 & 397 & 0.16 & 0.56 & 6.54 & 2.04 & 27 & 320 \\
\hline $42 X-6(104-107)$ & 368 & 401 & 0.08 & 0.30 & 4.33 & 1.58 & 18 & 274 \\
\hline $43 X-4(0-150)$ & 373.5 & 402 & 0.10 & 0.45 & 4.73 & 1.71 & 26 & 276 \\
\hline $43 X-5(0-150)$ & 375 & 401 & 0.13 & 0.64 & 4.87 & 1.93 & 33 & 252 \\
\hline $46 \times-4(59-61)$ & 402.5 & 415 & 0.09 & 0.49 & 4.52 & 1.93 & 25 & 234 \\
\hline $47 X-2(60-62)$ & 409 & 406 & 0.07 & 0.37 & 5.15 & 1.7 & 21 & 302 \\
\hline $49 X-4(63-64)$ & 431 & 395 & 0.10 & 0.34 & 4.03 & 2.05 & 16 & 196 \\
\hline $53 \mathrm{X}-6(120-122)$ & 474 & 409 & 0.12 & 0.84 & 4.67 & 1.39 & 60 & 335 \\
\hline $55 X-2(73-75)$ & 485 & 399 & 0.10 & 0.29 & 5.95 & 2.27 & 12 & 262 \\
\hline
\end{tabular}

Abbreviations: $\mathrm{S}_{1} \mathrm{mg}(\mathrm{HC} / \mathrm{g}$ rock $)=$ volatile hydrocarbons; $\mathrm{S}_{2}(\mathrm{mg} \mathrm{HC} / \mathrm{g}$ rock $)=\mathrm{ker}$ ogen-derived hydrocarbons; $\mathrm{S}_{3}$ (mg CO $\mathrm{CO}_{2} / \mathrm{g}$ rock) = organic $\mathrm{CO}_{2}$ from kerogen; $\mathrm{TOC}=$ total organic carbon; $\mathrm{HI}\left(100 \mathrm{~S}_{2} / \mathrm{C}_{\mathrm{org}}\right)=$ Hydrogen Index, OI $\left(100 \mathrm{~S}_{3}\right)$ $\left.\mathrm{C}_{\text {org }}\right)=$ Oxygen Index; $\mathrm{T}_{\max }=$ temperature $\left({ }^{\circ} \mathrm{C}\right)$ of maximum hydrocarbon generation from kerogen.

tensity and susceptibility results were obtained and will be used in conjunction with rock magnetic studies of these sediments.

Few measurements were made upon individual discrete samples, as the shipboard laboratory was not considered sufficiently free of spurious magnetic fields to avoid problems with viscous remanence to which the sediments seem prone. Consequently, remanence measurements of discrete samples were deferred to shore-based facilities where a controlled, shielded magnetic environment can be used to store samples prior to measurement. Four discrete samples from the second piston core of Hole 717B were subjected to stepwise AF demagnetization through $30 \mathrm{mT}$ and their remanence measured. Two of these samples yielded stable end points in the demagnetization process, and two appeared to acquire an ARM in the Schonstedt demagnetizer. The samples displaying stable end points yielded magnetic inclinations of -12.5 and -21.9 degrees, compatible with the present day field value for the site location.

\section{Remanent Magnetic Intensity}

The remanent magnetization of the archive half of each core from Holes 717B and 717C was measured using a pass through, three-component cryogenic magnetometer made by $2-\mathrm{G}$ Enterprises. The magnetometer is fitted with a three-axis alternating field (AF) demagnetizer with a maximum field of $9 \mathrm{mT}$. Discrete samples were also measured using this system. Demagnetization of discrete samples beyond $9 \mathrm{mT}$, however, was carried out using a Schonstedt AC Geophysical Specimen Demagnetizer (Model GSD-1). The natural remanent magnetization (NRM) of most core sections was measured using a $5-\mathrm{cm}$ spacing. Each core section was then demagnetized and its remanence remeasured. Initially, several sections were demagnetized over a range of $\mathrm{AF}$ field values to monitor the effect of the demagnetization upon the intensity and direction of remanence. Based upon the results of these measurements, all subsequent cores were demagnetized using the maximum field available (i.e., $9 \mathrm{mT}$ ). The range of NRM intensities observed was very large, from 0.03 $\mathrm{mA} / \mathrm{m}$ to greater than $1000 \mathrm{~mA} / \mathrm{m}$. Prior to demagnetization, approximately $20 \%$ of the 222 sections measured contained sediments too magnetic to be measured with the cryogenic magnetometer. In all but two cases, the AF demagnetization reduced the intensity to the point where the remanence could be measured, although many cores remained strongly magnetic $(>100$ $\mathrm{mA} / \mathrm{m})$. 


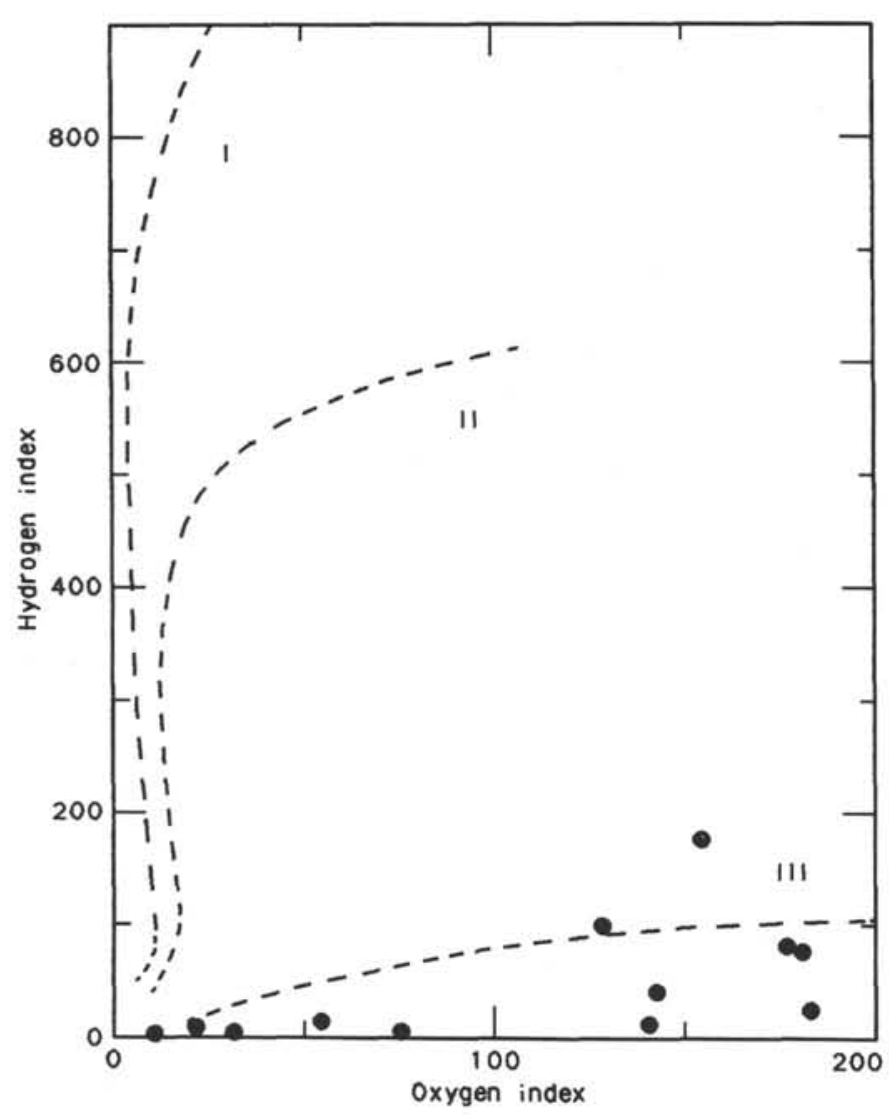

Figure 10. Hydrogen and Oxygen indices ( $\mathrm{HI}$ and $\mathrm{OI}$ ) obtained from Rock-Eval pyrolysis of 18 samples from Hole $717 \mathrm{C}$ and plotted on a van Krevelen-type diagram.

More often than not, where the sediments were too magnetic to measure, it was the vertical component of the magnetization that exceeded the measurement capability of the magnetometer. Thus a strong axial field, directed vertically upward, appears to have been imparted to the core by either the core barrel or drill pipe. In an attempt to remove this magnetic overprint, core barrels were demagnetized (using the AF setting on the Magnaflux apparatus) until the field measured with a hand-held magnetometer was less than $0.1 \mathrm{mT}$ over most of their lengths. After only one trip down the drill pipe, however, the core barrels were found to be strongly magnetized once again. It seemed that either the drill pipe or the rotating barrel of the XCB produces a strong vertical magnetic field through which the core material must pass on its way to the surface. This overprint was substantially, but not completely, removed by subjecting the core to alternating fields of $9 \mathrm{mT}$. Figure 19 shows a comparison of the intensity of magnetization of Core 116-717C-29X for NRM, 5and 9-mT demagnetization measurements. The strongly magnetized portion of the core underwent a dramatic reduction in intensity during demagnetization suggesting that the overprint in this portion was carried mostly by low-coercivity grains. The more weakly magnetized portion, on the other hand, appeared little changed by exposure to the $9-\mathrm{mT}$ alternating field. When these changes in intensity were compared with the associated changes in magnetic inclination (Fig. 20), it is clear that a nearly vertical field component was removed by the demagnetization process. The overprint, however, was not completely removed by the 9-mT AF treatment, and inclinations were still biased towards higher than expected negative values.

Figure 21 shows the variation in magnetic intensity with depth of Hole $717 \mathrm{C}$ core material after AF demagnetization with a
9-mT field. Although there was a large scatter in the values, there were a number of significant peaks that clustered into zones. These zones were observed at depths of 45-70, 100-120, $280-320,580-630$, and $760-820$ mbsf and presumably reflect either greater concentrations of magnetic grains in these layers or, alternatively, a change in the magnetic mineralogy at these depths. The zones correspond approximately with concentrations of sand and silt layers although not all such layers were associated with large remanent intensities. There are several depth intervals where the remanent intensity was significantly lower, e.g., 180-200 and 480-540 mbsf. In the upper part of the hole many of these low values appeared to correspond with the greenish biogenic turbidites seen in Unit III (see "Lithostratigraphy" section, this chapter). In the lower part of the hole, the low values were more closely related to the gray muds and pelagic clays which occur in Subunit IVd. The corresponding lithology in Unit III, however, was associated with both high and low values and, consequently, a more detailed study of the relationship between the remanent magnetization and lithologic type is required before the any meaningful correlations can be developed. The correlation of the remanent intensity with the susceptibilty depth profile is discussed below.

\section{Magnetostratigraphy}

Site 717 is located very near to the Equator and, consequently, there is no appreciable change in magnetic inclination associated with a reversal of the geomagnetic field. Reversals must be identified, therefore, by a 180 -degree change in declination. Consequently, to identify the magnetic reversal pattern of the sediments, it is necessary to either azimuthally orient the core or have long sections in which there is little or no rotation of core material. In this hole, piston coring was abandoned after only $13.5 \mathrm{~m}$ and the remainder of the hole cored with the XCB, which rotates as it cores. The magnetic inclinations and declinations obtained from the limited piston core material were relatively uniform yielding inclinations of about -10 to -20 degrees. With the XCB it is not possible to obtain oriented cores with which to determine reliable declinations and as a consequence very little magnetostratigraphic information is available for this site. The almost random pattern of magnetic declinations obtained from the XCB core material may be attributed to the coring process, although in the upper part of the section there is little visual evidence of the biscuiting that becomes ubiquitous below approximately 350 mbsf. The lower $450 \mathrm{~m}$ of the core was strongly disturbed by drilling, and many of the biscuited pieces are tilted as well as presumably rotated in the core barrel, resulting in the inclination data also being unreliable.

Predicted magnetic inclinations are close to zero for this site but observed values differed appreciably from this (Fig. 20). The measurements were substantially biased, especially NRM measurements, toward more negative values with some exceeding -70 degrees. While this bias was partially removed during demagnetization, some of it certainly remained in the paleomagnetic data, so many measured inclinations are suspect. In spite of this, an attempt was made to characterize the magnetic inclinations observed after AF demagnetization by looking at the predominance of polarity within individual sections of the core. The inclination data showed three major zones: (a) 0-150 mbsf, in which the values were almost entirely negative (i.e., normal polarity); (b) 220-400 mbsf, which was characterized by many reverse polarity zones; and (c) 500-825 mbsf, which was nearly all normal polarity.

\section{Magnetic Susceptibility}

Measurements of volume susceptibility, $k$, were made on whole, unsplit 1.5-m sections of core from Holes 717B and 717C. 
Table 8. Interstitial water geochemical data, Site 717.

\begin{tabular}{|c|c|c|c|c|c|c|c|c|c|c|c|c|c|c|c|c|c|c|c|c|c|}
\hline \multirow[b]{3}{*}{ Hole } & \multirow[b]{3}{*}{ Core } & \multirow[b]{3}{*}{ Type } & \multirow[b]{3}{*}{ Sect. } & \multirow{2}{*}{\multicolumn{2}{|c|}{$\begin{array}{l}\text { Interval } \\
(\mathrm{cm})\end{array}$}} & \multicolumn{2}{|c|}{ Method: } & \multirow{3}{*}{$\begin{array}{c}\mathrm{T} \\
\mathrm{pH}\end{array}$} & \multirow{3}{*}{$\frac{\mathrm{T}}{\begin{array}{c}\text { Alkalinity } \\
\mathrm{mmol} / \mathrm{L}\end{array}}$} & \multirow{3}{*}{$\begin{array}{c}\text { R } \\
\begin{array}{c}\text { Salinity } \\
\mathrm{g} / \mathrm{kg}\end{array}\end{array}$} & \multirow{3}{*}{ 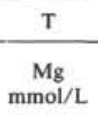 } & \multirow{3}{*}{$\frac{\mathrm{T}}{\mathrm{Ca}} \mathrm{\textrm {mmol } / \mathrm { L }}$} & \multirow{3}{*}{$\frac{\mathrm{T}}{\mathrm{Cl}} \mathrm{\textrm {Cl }}$} & \multirow{3}{*}{$\frac{1}{\underset{\mathrm{SO}_{4}}{\mathrm{mmol} / \mathrm{L}}}$} & \multirow{3}{*}{$\frac{\mathrm{S}}{\underset{\mu \mathrm{mol} / \mathrm{L}}{\mathrm{PO}_{4}}}$} & \multirow{3}{*}{$\frac{\mathrm{S}}{\underset{\mu \mathrm{NO}{ }_{3} / \mathrm{L}}{\mathrm{N}^{2}}}$} & \multirow{3}{*}{$\frac{\mathrm{S}}{\underset{\mu \mathrm{mol} / \mathrm{L}}{\mathrm{NH}_{4}}}$} & \multirow{3}{*}{$\frac{\mathrm{S}}{\underset{\mu \mathrm{mol} / \mathrm{L}}{\mathrm{Si}}}$} & \multirow{3}{*}{$\begin{array}{l}\mathrm{Na}+\mathrm{K} \\
\mathrm{mmol} / \mathrm{L}\end{array}$} & \multirow{3}{*}{$\frac{\mathrm{Na}+\mathrm{K}}{\mathrm{Cl}}$} & \multirow{3}{*}{$\begin{array}{l}\text { I.A.P. } \\
\mathrm{Ca}^{2+}(\text { Alk. })\left(\mathrm{H}_{3} \mathrm{O}^{+}\right)\end{array}$} \\
\hline & & & & & & Depth & Water & & & & & & & & & & & & & & \\
\hline & & & & Top & Bot & (mbsf) & $(\mathrm{mL})$ & & & & & & & & & & & & & & \\
\hline A & 1 & H & 4 & 145 & 150 & 4.6 & 60 & 7.41 & 9.52 & 34.0 & 49.08 & 10.25 & 557 & 21.7 & 20.1 & 0.0 & 640 & 505 & 485 & 0.871 & 281 \\
\hline C & 5 & $\mathrm{x}$ & 1 & 145 & 150 & 37.9 & 17 & 8.35 & 14.50 & 33.2 & 41.68 & 6.00 & 560 & 0.6 & 19.3 & 0.9 & 2100 & 215 & 480 & 0.857 & 2181 \\
\hline c & 8 & $\mathrm{x}$ & 1 & 140 & 150 & 66.4 & 64 & 7.60 & 8.69 & 33.8 & 40.18 & 6.53 & 560 & 2.9 & 20.4 & 0.0 & 2300 & 330 & 481 & 0.859 & 253 \\
\hline c & 14 & $\mathrm{x}$ & 1 & 140 & 150 & 104.4 & 75 & 7.48 & 7.38 & 33.3 & 40.38 & 6.80 & 558 & 4.3 & 16.6 & 0.0 & 2900 & 340 & 480 & 0.860 & 170 \\
\hline c & 20 & $\mathrm{x}$ & 3 & 140 & 150 & 154.9 & 12 & 8.40 & 16.31 & 32.5 & 44.17 & 4.05 & 551 & 1.4 & 40.1 & 7.5 & 2900 & 410 & 474 & 0.860 & 1860 \\
\hline c & 23 & $\hat{x}$ & 3 & 140 & 150 & 183.4 & 14 & 8.25 & 15.00 & 33.1 & 45.21 & 5.15 & 552 & 2.9 & 11.1 & 0.0 & 1500 & 465 & 472 & 0.855 & 1540 \\
\hline c & 26 & $\mathrm{x}$ & 4 & 140 & 150 & 213.4 & 20 & - & 11.70 & 32.0 & 40.72 & 6.75 & 553 & 1.4 & 9.8 & 0.0 & 1800 & 645 & 472 & 0.854 & - \\
\hline C & 29 & $\mathrm{x}$ & 4 & 140 & 150 & 241.9 & 30 & - & 8.90 & 31.7 & 36.72 & 7.34 & 556 & 2.0 & 6.2 & 0.0 & 1800 & 575 & 481 & 0.865 & - \\
\hline c & 32 & $\mathrm{x}$ & 4 & 140 & 150 & 270.4 & 9 & 8.15 & 5.45 & 31.7 & 39.62 & 9.49 & 532 & 4.3 & - & 0.2 & 1600 & 255 & 448 & 0.842 & 818 \\
\hline c & 35 & $\mathrm{x}$ & 3 & 140 & 150 & 297.3 & 16 & 8.05 & 5.07 & 32.2 & 34.81 & 10.38 & 545 & 2.9 & 2.46 & 0.2 & 1900 & 305 & 465 & 0.853 & 661 \\
\hline C & 38 & $\mathrm{x}$ & 3 & 140 & 150 & 325.8 & 71 & 7.88 & 5.09 & 32.4 & 33.09 & 12.18 & 544 & 4.3 & 3.12 & 0.0 & 1140 & 203 & 467 & 0.858 & 527 \\
\hline C & 42 & $\mathrm{x}$ & 4 & 140 & 150 & 365.3 & 10 & 8.10 & 3.90 & 29.8 & 33.27 & 14.27 & 521 & 1.4 & 4.2 & 0.0 & 850 & 260 & 435 & 0.835 & 785 \\
\hline c & 45 & $\hat{x}$ & 4 & 140 & 150 & 393.9 & 7 & 8.15 & 3.40 & 31.9 & 32.88 & 15.26 & 542 & 7.2 & 6.5 & 2.7 & 1170 & 253 & 403 & 0.854 & 821 \\
\hline c & 48 & $\mathrm{x}$ & 4 & 140 & 150 & 422.4 & 7 & 8.00 & 3.45 & 31.3 & 33.25 & 16.23 & 528 & 3.7 & 3.4 & & 820 & 215 & 440 & 0.833 & 627 \\
\hline C & 51 & $x$ & 3 & 140 & 150 & 449.4 & 12 & 8.00 & 2.80 & 31.2 & 30.87 & 16.71 & 529 & 4.1 & 4.4 & & 860 & 195 & 445 & 0.841 & 524 \\
\hline C & 54 & $\mathrm{x}$ & 4 & 140 & 150 & 479.4 & 8 & 8.05 & 3.24 & 30.0 & 29.35 & 17.17 & 505 & 1.5 & 2.9 & & 1510 & 160 & 418 & 0.828 & 699 \\
\hline C & 57 & $x$ & 4 & 140 & 150 & 507.9 & 61 & 8.07 & 2.55 & 32.1 & 26.49 & 16.03 & 552 & 3.0 & 0.63 & & 1800 & 132 & 475 & 0.861 & 538 \\
\hline C & 60 & $\mathrm{x}$ & 2 & 140 & 150 & 533.4 & 6 & 7.95 & 2.90 & 27.2 & 32.34 & 17.77 & 508 & 3.7 & 1.7 & & 1290 & 157 & 418 & 0.823 & 647 \\
\hline C & 64 & $\mathrm{x}$ & 2 & 130 & 140 & 571.4 & 20 & 7.95 & 3.23 & 32.3 & 30.02 & 17.09 & 559 & 6.1 & 2.8 & & 1210 & 222 & 480 & 0.859 & 551 \\
\hline C & 67 & $x$ & 1 & 140 & 150 & 598.4 & 36 & 7.95 & 4.74 & 32.3 & 28.53 & 17.00 & 563 & 5.3 & 4.6 & & 610 & 200 & 487 & 0.865 & 804 \\
\hline c & 70 & $\hat{x}$ & 4 & 130 & 140 & 631.4 & 44 & 8.07 & 1.407 & 32.7 & 25.67 & 16.57 & 554 & 2.8 & 2.1 & & 1020 & 160 & $\begin{array}{l}401 \\
476\end{array}$ & 0.860 & 307 \\
\hline C & 74 & $\mathrm{x}$ & 1 & 140 & 150 & 664.9 & 48 & 7.95 & 2.55 & 33.0 & 20.95 & 17.13 & 568 & 3.7 & 2.0 & & 750 & 188 & 491 & 0.865 & 436 \\
\hline C & 77 & $\mathrm{x}$ & 4 & 130 & 140 & 697.8 & 3 & 8.05 & - & 27.2 & 22.71 & 17.28 & 472 & 2.5 & - & & - & 100 & $>397$ & $>0.840$ & - \\
\hline C & 80 & $\mathrm{x}$ & 2 & 140 & 150 & 723.4 & 20 & 8.05 & 2.92 & 32.4 & 25.30 & 18.84 & 509 & 3.4 & 2.5 & & 510 & 217 & 490 & 0.862 & 691 \\
\hline C & 84 & $\mathrm{x}$ & 2 & 140 & 150 & 761.4 & 30 & 8.10 & 1.86 & 32.8 & 21.22 & 18.34 & 568 & 2.3 & 2.0 & & 410 & 215 & 494 & 0.869 & 481 \\
\hline C & 87 & $\mathrm{x}$ & 1 & 140 & 150 & 788.4 & 25 & 7.90 & 3.00 & 33.7 & 20.95 & 18.85 & 570 & 2.3 & 2.2 & & 580 & 195 & 498 & 0.874 & 504 \\
\hline c & 91 & $\mathrm{x}$ & 3 & 140 & 150 & 823.1 & 27 & 7.45 & 16.81 & 33.9 & 18.66 & 22.46 & 557 & 3.2 & 2.1 & & 650 & 1085 & 498 & 0.894 & 1192 \\
\hline
\end{tabular}

$\mathrm{T}=$ Hand Titration; $\mathrm{R}=$ Refractometer; $\mathrm{I}=$ Ion Chromotography; $\mathrm{S}=$ Spectrophotometer. 


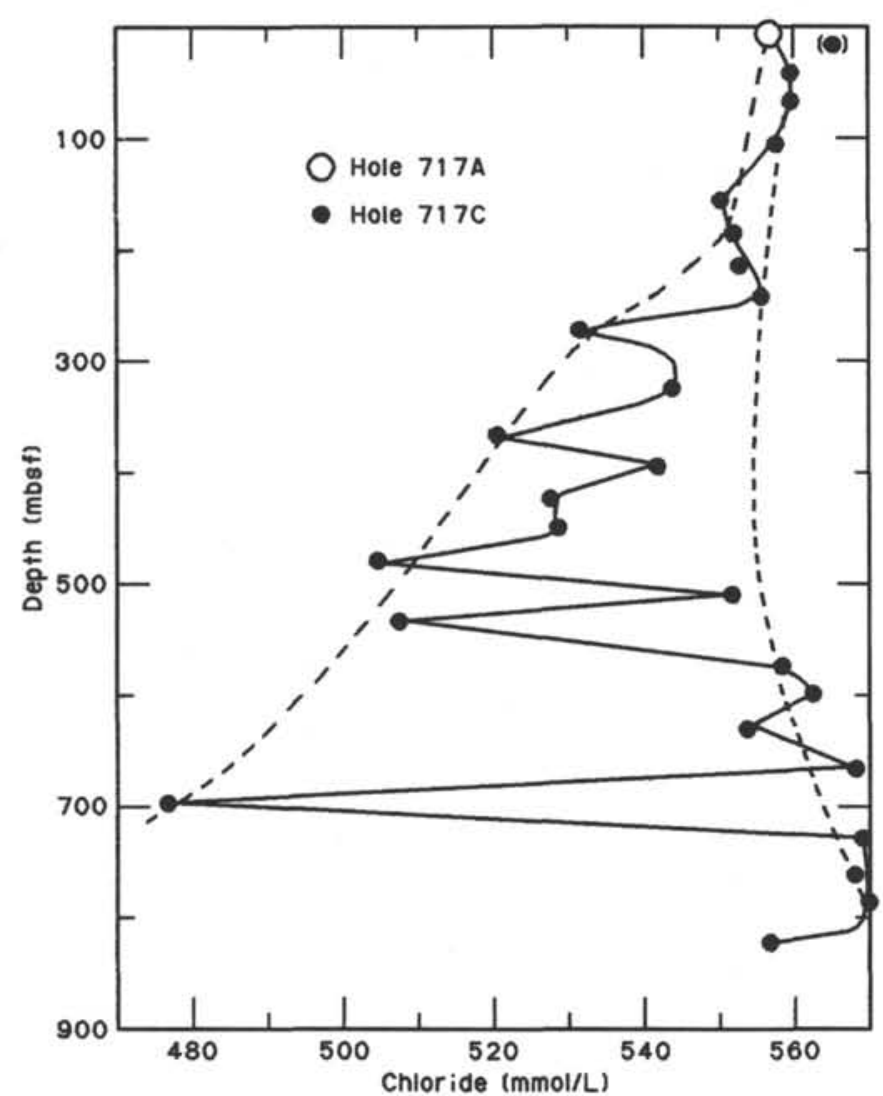

Figure 11. Cl vs. depth at Site 717. Dashed curves: see text.

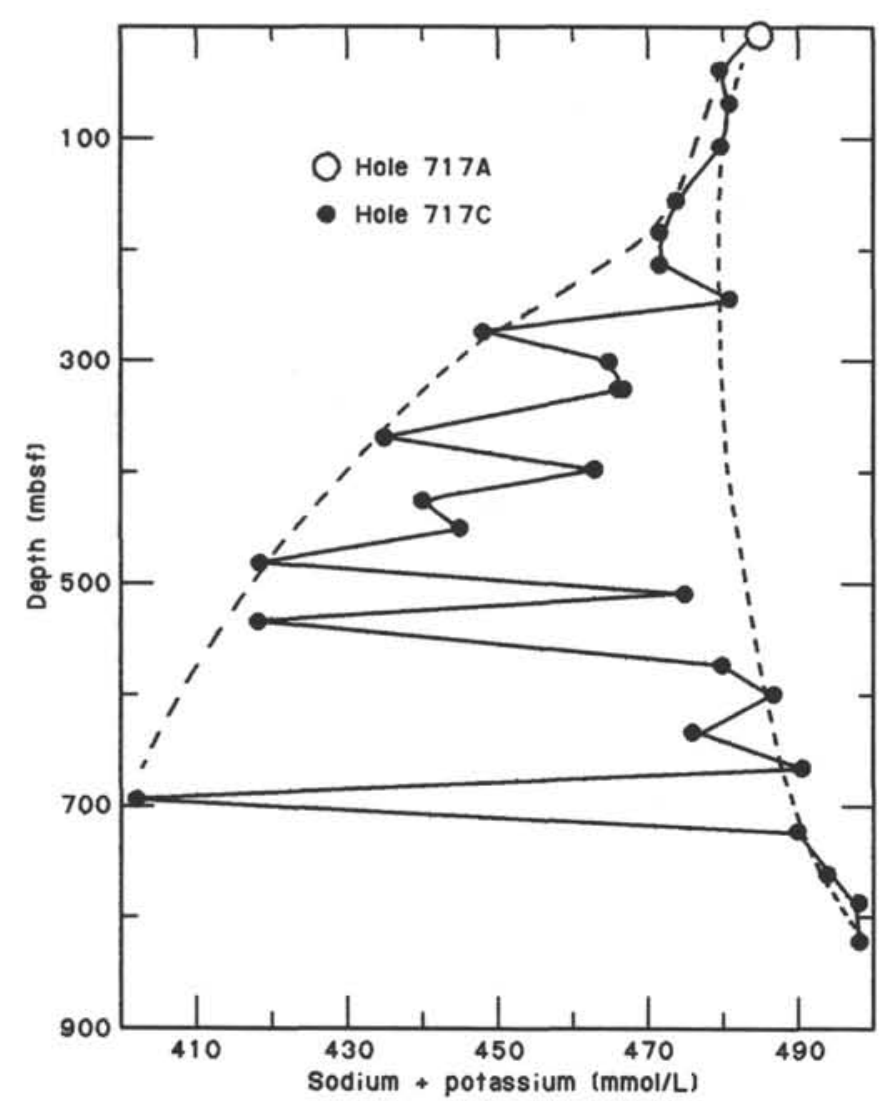

Figure 12. Na $+\mathrm{K}$ vs. depth at Site 717. Dashed curves: see text.

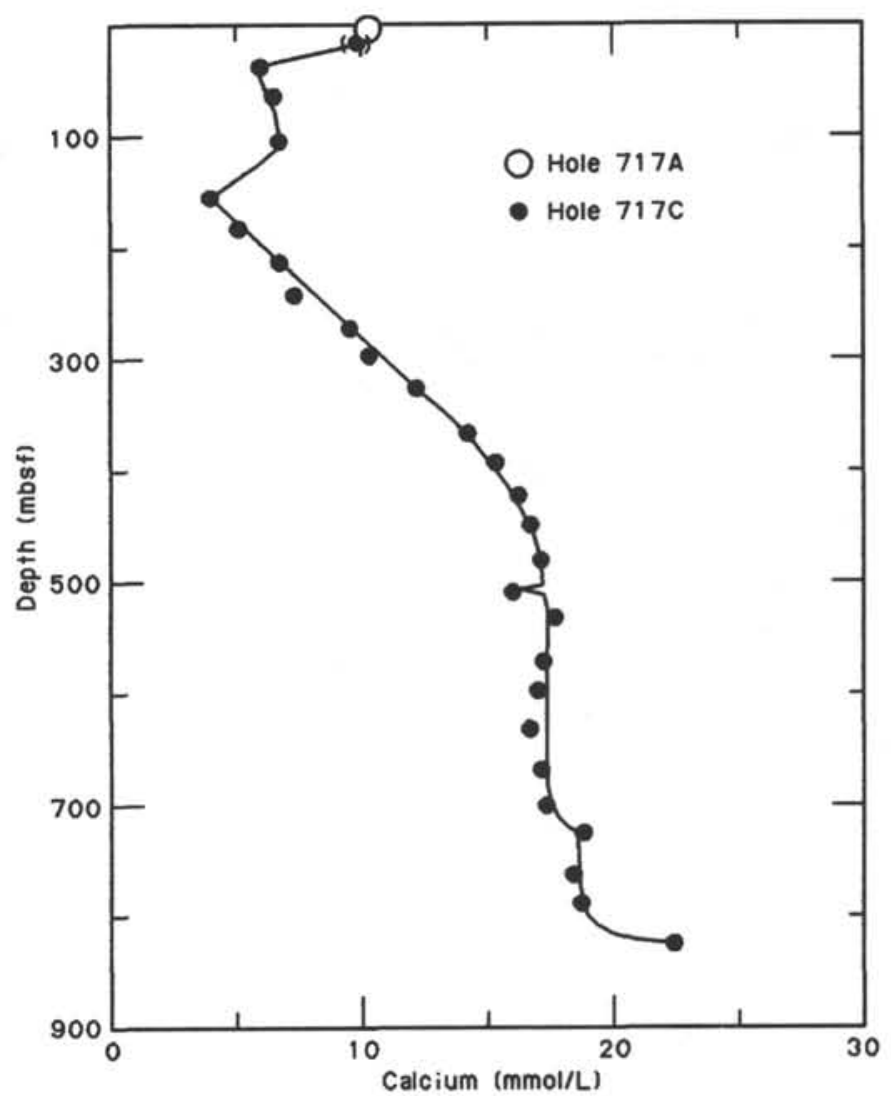

Figure 13. Ca vs. depth at Site 717.

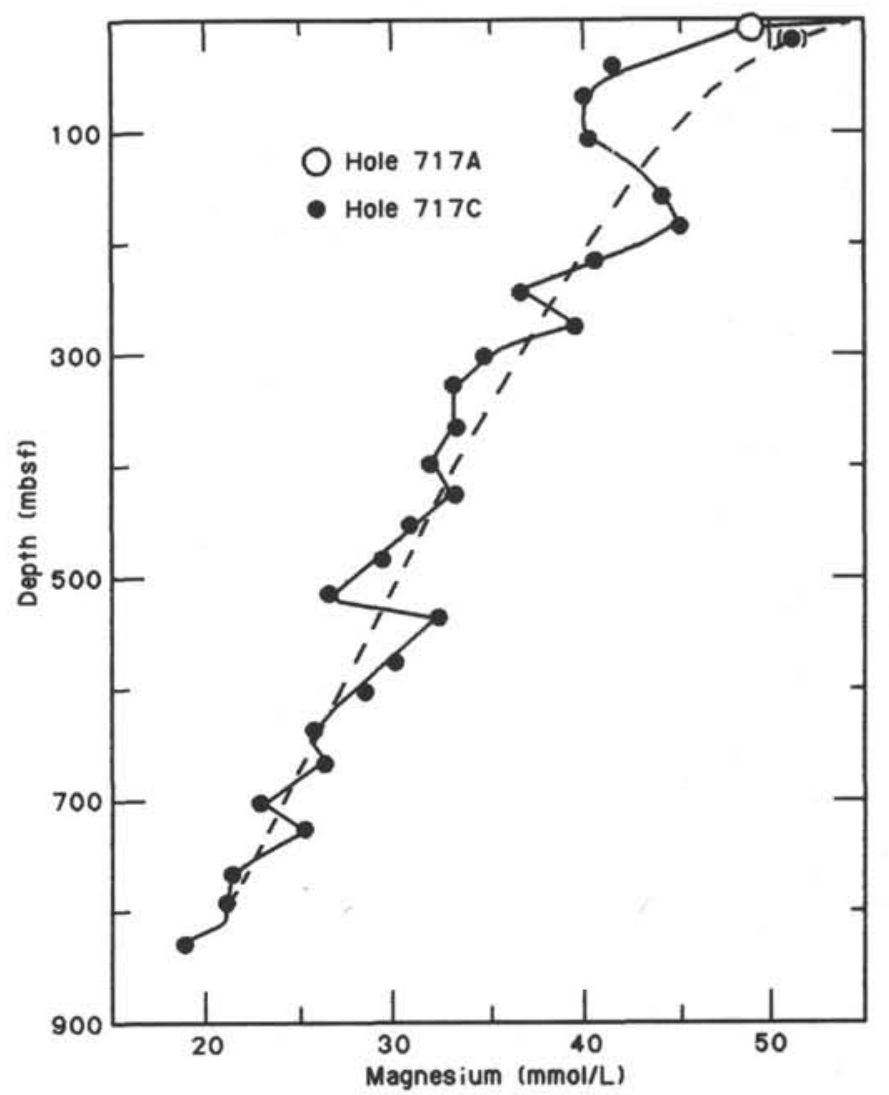

Figure 14. Mg vs. depth at Site 717. 


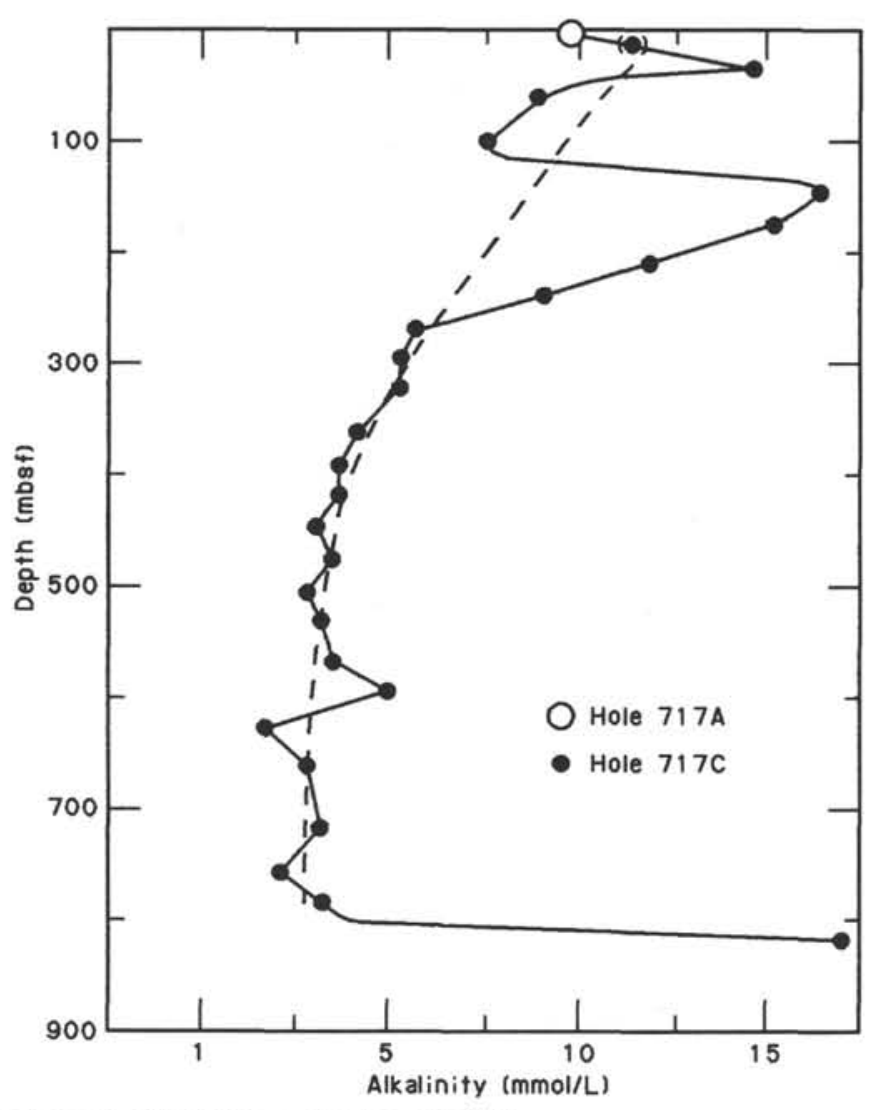

Figure 15. Alkalinity vs. depth at Site 717.

In all, 8,696 susceptibility measurements were made on Site 717 cores. Only 183 of these are from Hole $717 \mathrm{~B}$, specifically Core $116-717 \mathrm{C}-2 \mathrm{H}$. The remainder were obtained from Cores 116$717 \mathrm{C}-2 \mathrm{H}$ to $116-717 \mathrm{C}-91 \mathrm{X}$. However, as the two holes were situated no more than a few tens of meters apart and were drilled so that the bottom of Hole 717B and the top of the first-recovered core of Hole $717 \mathrm{C}$ are coincident, the results from both holes are combined in the following analysis and discussion.

Site 717 cores were strongly magnetic in comparison with most deep-sea sediments. Although the magnetic susceptibility values range from 5 to $897 \mathrm{cgs}$, the majority of the measurements were between 20 and $80 \mathrm{cgs}$. However, the susceptibility vs. depth record (Fig. 22) was punctuated with numerous highamplitude spikes.

On closer examination, the susceptibility record in Figure 22 is not as erratic as it appears at first glance. Susceptibility peaks were almost always correlatable with turbidites. In particular, the highest spikes were measured from dark-gray mud turbidites. Additionally, many silt turbidites gave rise to moderate susceptibility peaks. However, neither relationship displayed a simple one-to-one correspondence. Some dark-gray mud turbidites yielded only small susceptibility peaks, and a few gave none at all. Evidently, the factors that controlled the color and type of sediment do not completely regulate the magnetic minerals, yet there was clearly a close relationship.

A detailed examination also revealed that the susceptibility peaks can be divided into five categories based on shape. The most common morphology was symmetric, with the highest susceptibility values recorded near the center and approximately equal lengths of rising and falling values on either side (Fig. 23). These spikes varied in width from about 10 to $15 \mathrm{~cm}$ (the lower limit of resolution with the 5-cm measurement spacing) to 1-2 m. About $40 \%$ of the observed peaks could be placed in this

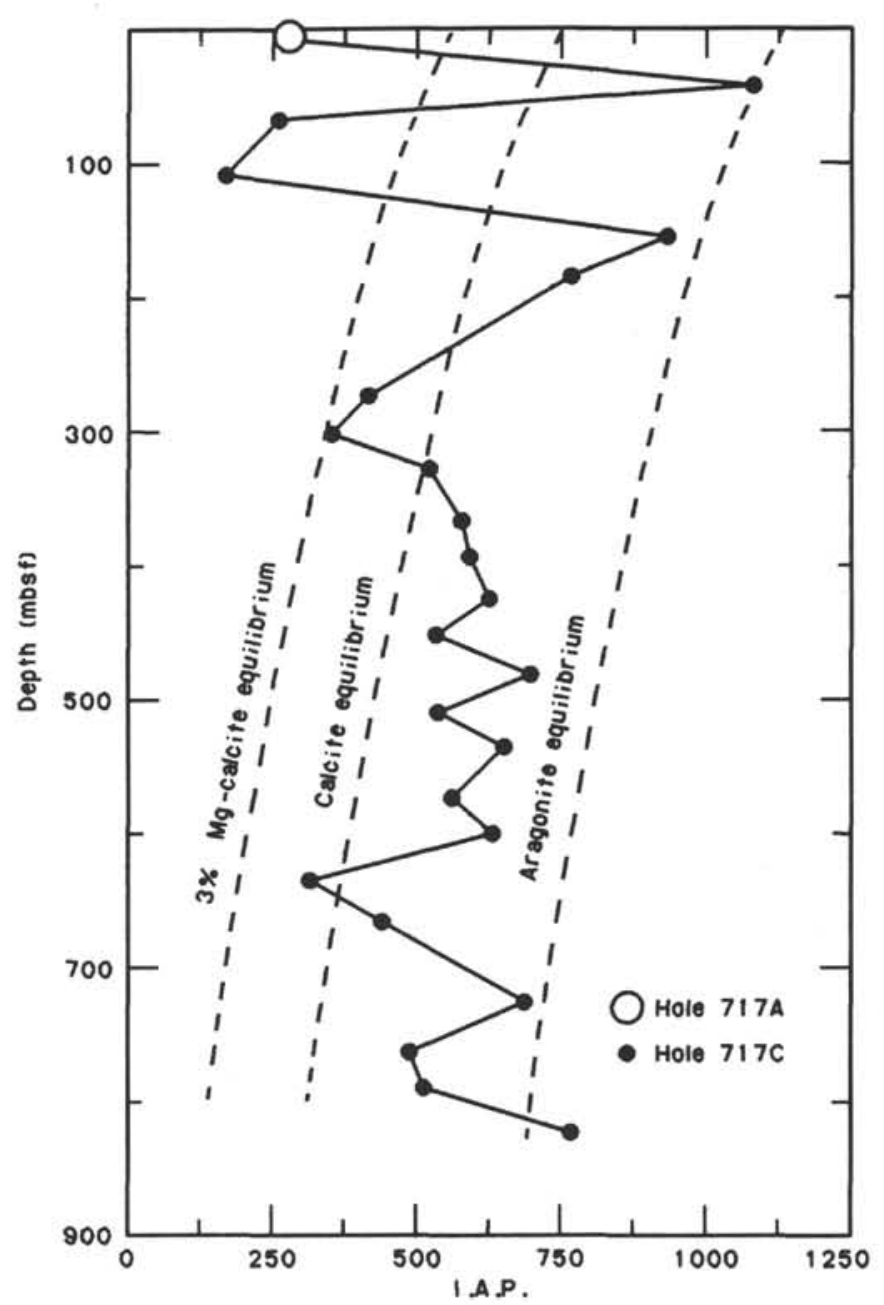

Figure 16. I.A.P. of calcium carbonate vs. depth. The calcite equilibrium line as well as aragonite and $3 \% \mathrm{Mg}$ calcite has been corrected for temperature and pressure of the samples.

category. Figure 23 shows an example of the correlation between these spikes and dark-gray mud turbidites.

The next most common type of peak, comprising about $24 \%$ of those observed, was asymmetric with a slow rise in susceptibility with depth followed by an abrupt fall. Two examples from Core 116-717C-48X, which also displayed a good correlation with gray mud turbidites, are shown in Figure 24. The susceptibility values began to rise at the tops of several turbidites and reached large values at their bases. Being relatively heavy, the magnetic minerals apparently settled preferentially to the bottoms of these density-stratified layers. Graded behavior, such as this, was demonstrated by turbidites with widths from about $10-15 \mathrm{~cm}$ to $2-3 \mathrm{~m}$. Although not exclusively limited to any particular lithology, susceptibility peaks of this type appeared most commonly in the units characterized by gray mud turbidites.

Other types of susceptibility peaks appeared in lesser numbers. About $14 \%$ were flat-topped or multipeaked. These featured a rise in the susceptibility to a higher, nearly constant level or a series of smaller peaks, with a subsequent return to lower values. Another 7\% displayed twin peaks, at the top and bottom of the turbidite layer, often with higher than usual values in between. A few susceptibility peaks, about $4 \%$ of the those observed, appeared graded, but in the reverse sense. The highest values occurred abruptly at the top of the layer and decreased slowly with depth. These peaks were usually small in amplitude and width and often appeared multipeaked. Approximately $11 \%$ 


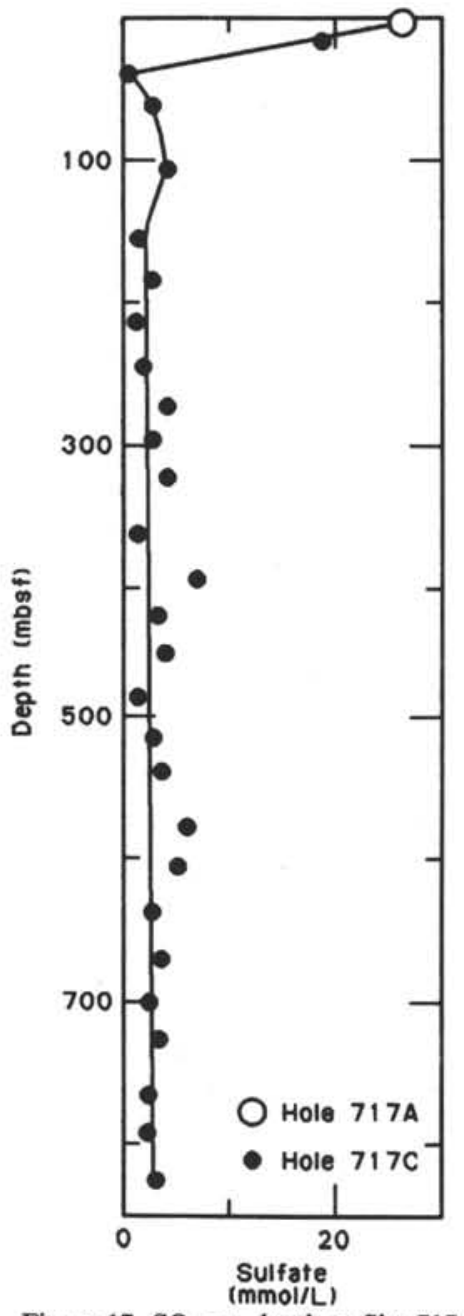

Figure 17. $\mathrm{SO}_{4}$ vs. depth at Site 717.

of the peaks could not be fitted into any of these categories, usually because they occurred at the top or bottom of a core or in an interval that was incompletely recovered. Interestingly, a few peaks combined two or more of these characteristics. For instance, a number of layers were noted in which there was a slow rise in susceptibility over several meters depth, similar to the graded behavior, but on top of the rise several thinner, symmetrical peaks occurred. Perhaps this phenomenon was a result of a graded layer consisting of a series of smaller, related turbidites.

It is not clear what minerals gave the sediments from Site 717 their strong magnetism. Detailed shore-based magnetic property studies are required to reveal their identities. However, two properties were evident from the shipboard analysis. First, the high-amplitude susceptibility peaks were correlated with strong remanent magnetization. Apparently, the magnetic susceptibility is carried mainly by a magnetic mineral that is ferromagnetic, eliminating from consideration some minerals, such as pyrite, which were found in Site 717 cores but are paramagnetic. As seen in Figure 24, the correlation between the remanent magnetic intensity and susceptibility can be quite close. Indeed, it might have been better were it not for the drilling disturbance of the core material, which tended to make the intensity values more erratic. Additionally, this relationship was evident on a larger scale as seen by comparison of Figure 22 with Figure 21 in the preceeding section. Second, the carrier of the remanent

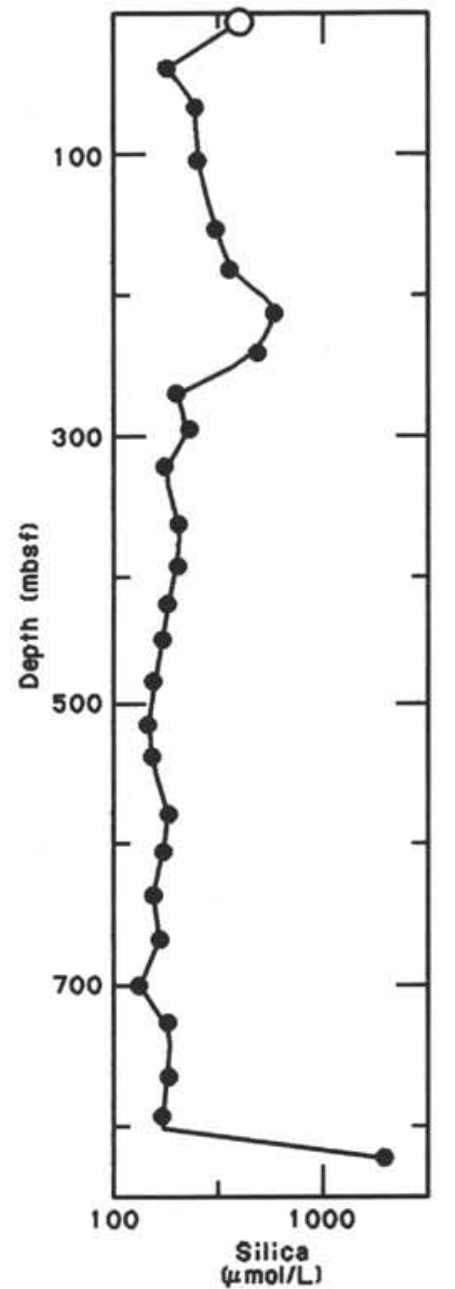

Figure 18. $\mathrm{SiO}_{2}$ vs. depth at Site 717 .

magnetism in many cases displayed a soft unstable behavior. It acquires a strong overprint from exposure to the magnetic field of the drill string. Moreover, this overprint was largely removed with relatively weak alternating magnetic fields. This fact indicated that the carrier of the magnetic remanence has a low coercivity.

The magnetic susceptibility record also contained some interesting features on a broad scale as well. In general, the units of silty turbidites gave rise to the most variable values with many small spikes (Fig. 25). These units apparently consist of many turbidites, with almost every one contributing a susceptibility spike. In the units characterized by mud turbidites, there were often layers of pelagic sediment and light, structureless mud between dark-gray turbidites. The pelagic sediments and light mud usually yielded relatively constant low susceptibility values broken by large spikes resulting from the dark-gray mud turbidites. Additionally, there was a variation with depth of the size of the spikes in Hole $717 \mathrm{C}$ that was not clearly related to the type of sediment. These variations were seen as pulses of high values at certain depths within the hole (Fig. 22). These pulses were a result of susceptibility peaks with higher amplitudes but not necessarily greater frequency. Prominent pulses were noted between approximately $250-310,400-480$, and $580-$ 620 mbsf. Comparing these pulses to the lithologic units in Hole $717 \mathrm{C}$ (see "Lithostratigraphy" section) they were seen to cross the unit boundaries. Evidently these pulses were controlled by 


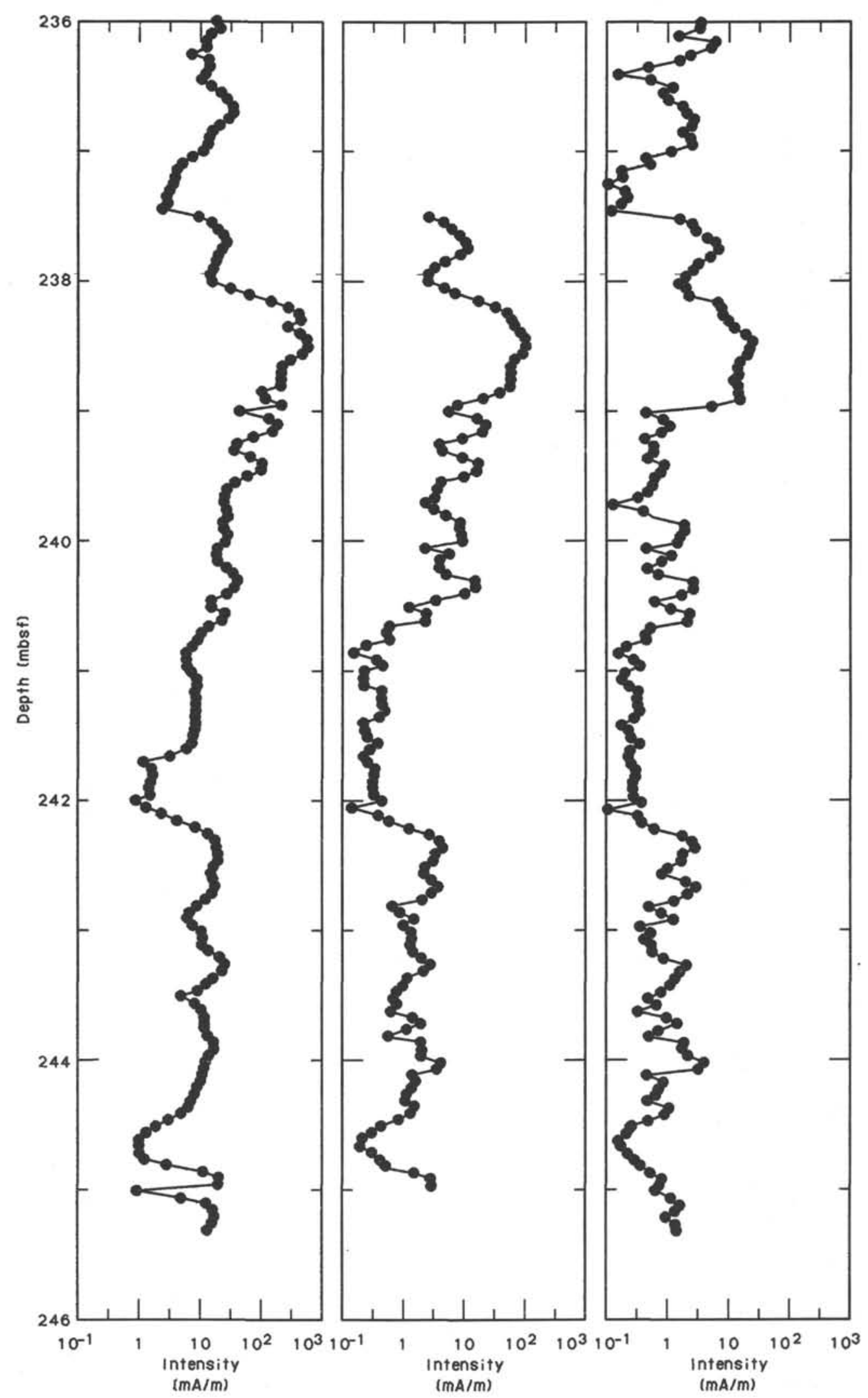

Figure 19. Remanent magnetic intensities vs. depth for Core 116-717C-29X for NRM, 5-, and 9-mT demagnetization measurements. 


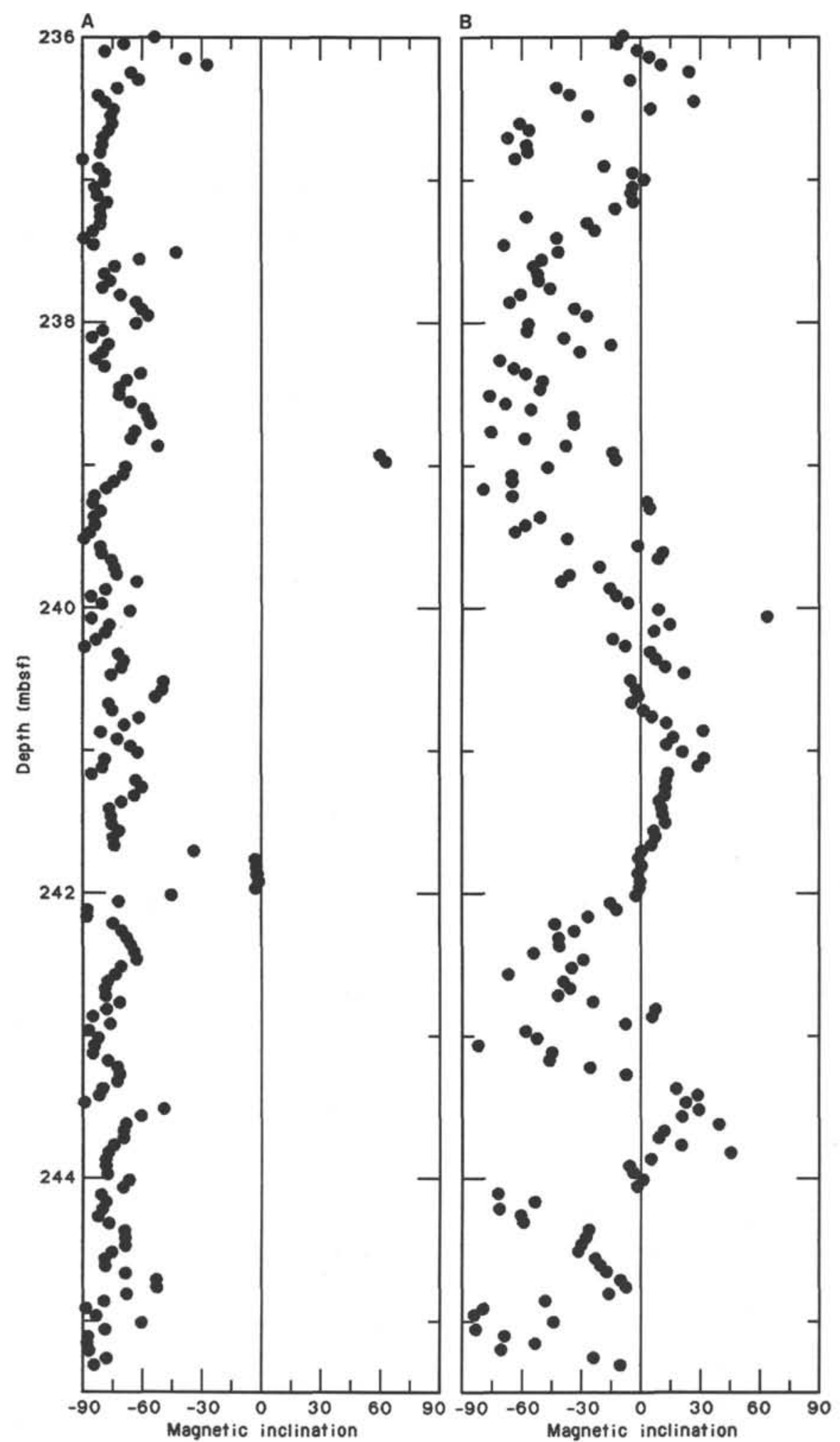

Figure 20. Magnetic inclinations vs. depth for Core 116-717C-29X. (A) NRM, and (B) 9-mT AF demagnetization measurements. Large negative inclination values of NRM are believed caused by overprint from drill pipe. 


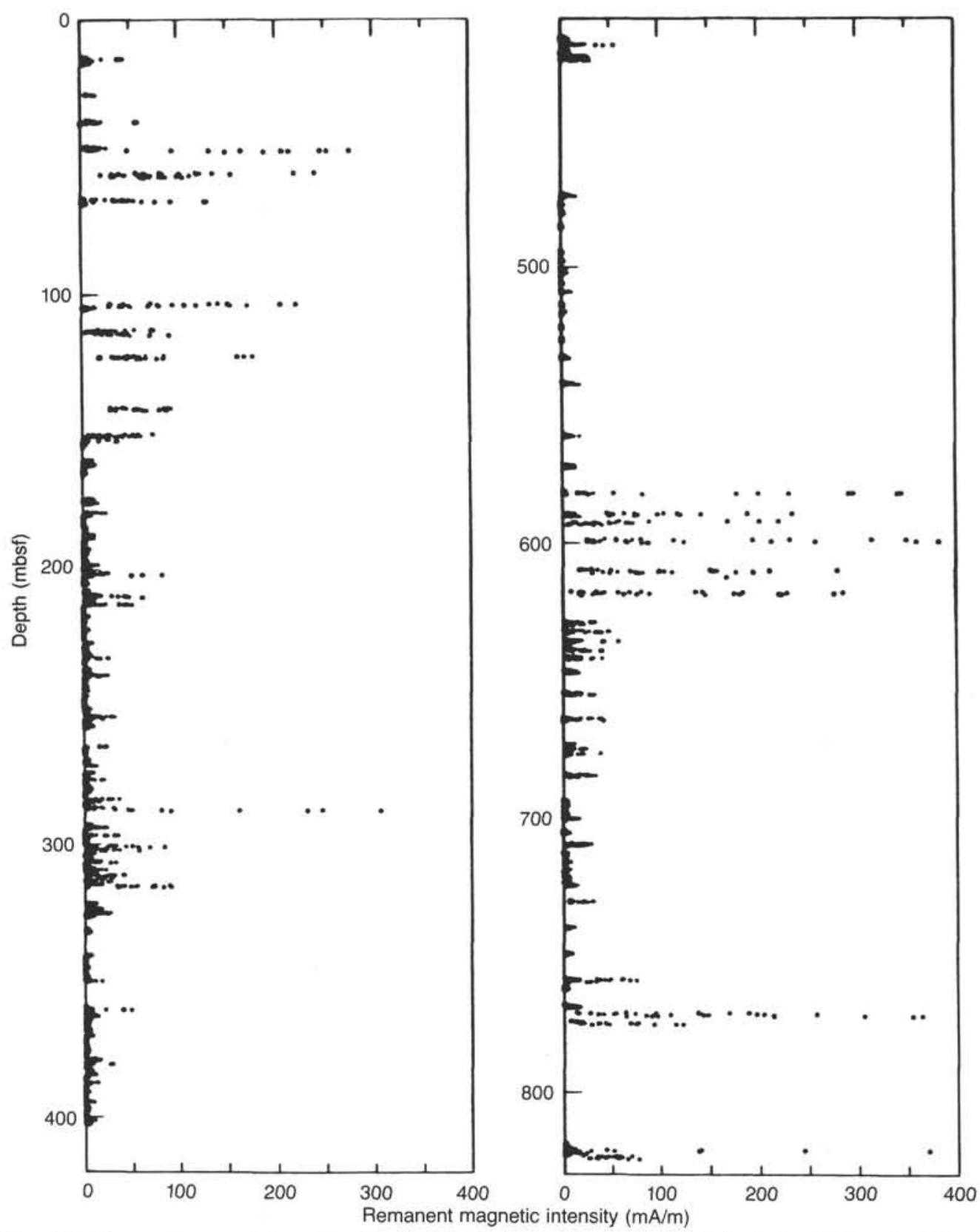

Figure 21. Remanent magnetic intensity after 9-mT AF demagnetization vs. depth for Holes 717B and 717C. Several values exceeding $400 \mathrm{~mA} / \mathrm{m}$ are not shown.

some process other than the sedimentation regime. Two other possible pulses occurred at the top and bottom of the hole, but these were less certain because of poor core recovery.

\section{PHYSICAL PROPERTIES}

\section{Introduction}

Cores 116-717A-1H, -717B-1H, -717B-2H, and -717C-2H were obtained by the Advanced Piston Core (APC). Cores 116717C-2X to $-717 \mathrm{C}-91 \mathrm{X}$ were recovered with the Extended Core Barrel (XCB). All cores were used for shipboard analysis of physical properties.

Physical properties measured routinely on all cores recovered at Site 717 include GRAPE density and thermal conductivity from full-round core sections, vane-shear strength, compressional wave velocity, and index properties from split sections (the meth- ods are described in detail in the Explanatory Notes). Results of physical properties measurements at Site 717 are summarized in Tables 9 to 13 .

\section{Index Properties}

Index properties include wet-bulk density, water content, porosity, and grain density. The measurements were made mainly on fine-grained deposits, with the following results.

Wet-bulk density (Fig. 26A) increased rapidly from $1.5 \mathrm{~g} /$ $\mathrm{cm}^{3}$ at the seafloor to about $1.75 \mathrm{~g} / \mathrm{cm}^{3}$ at $70 \mathrm{mbsf}$. Below this depth the wet-bulk density increased linearly to about $2.1 \mathrm{~g} / \mathrm{cm}^{3}$ at $810 \mathrm{mbsf}$. The silt samples had a wet-bulk density of $2.0-2.1$ $\mathrm{g} / \mathrm{cm}^{3}$.

The water content (related to wet weight; Fig. 26B) of the clays, silty clays, and claystones exhibited a large variation (15- 

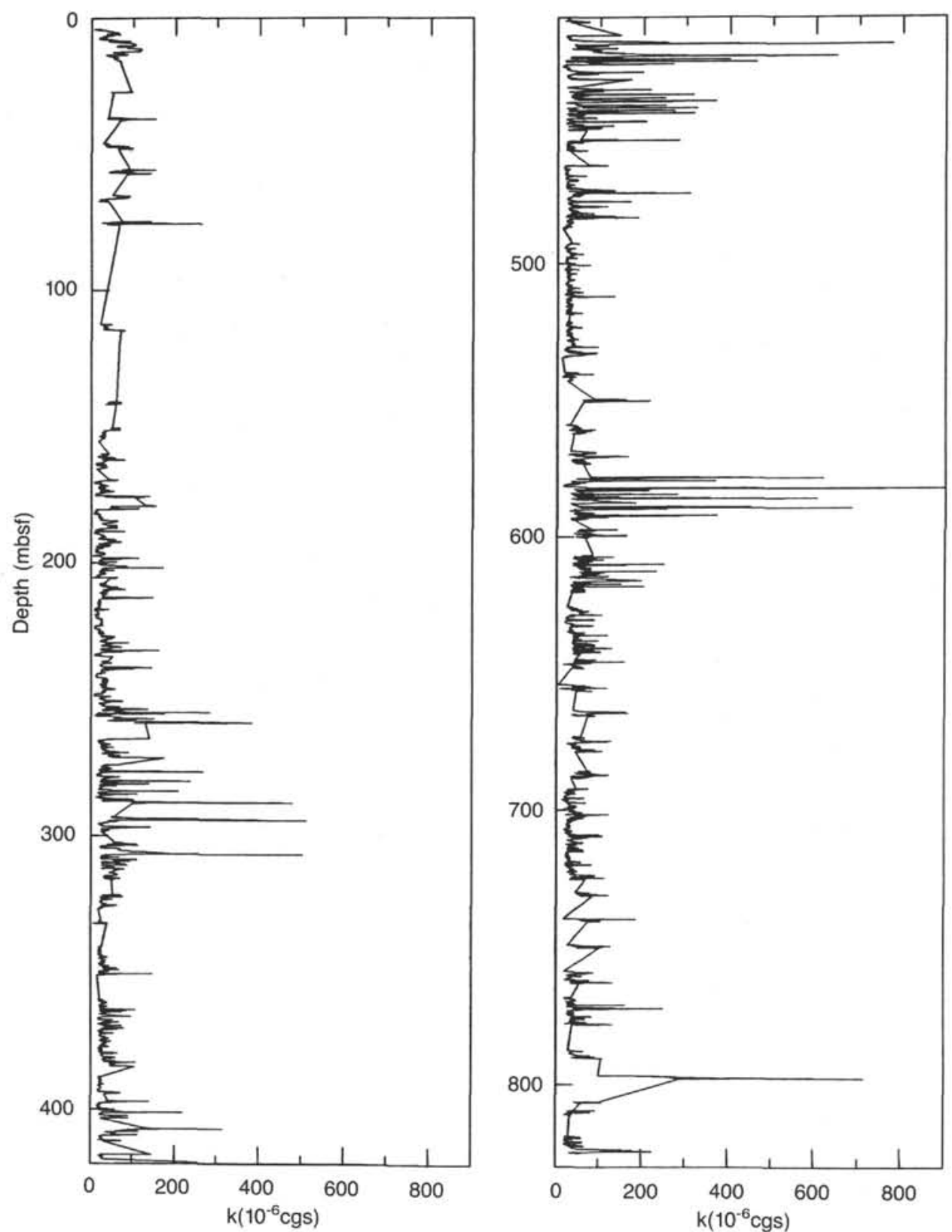

Figure 22. Whole core volume magnetic susceptibility measurements vs, depth for Site 717. Data from both Holes 717B and 717C are included. Susceptibility, $k$, is given on the abcissa in $10^{-6} \mathrm{cgs}$ units. Depth is shown vertically in meters below the seafloor. In the box on the left are plotted measurements of cores recovered from 0 to $420 \mathrm{mbsf}$; on the right, values from cores between 410 and $830 \mathrm{mbsf}$.

$60 \%$ ) over the entire drilled interval. Above $100 \mathrm{mbsf}$ the water content of fine-grained deposits ranged between 30 and $60 \%$. Below 100 mbsf the water content averaged $25-35 \%$, which is very close to the water content of sands.

Porosity (Fig. 26C) decreased downhole from a high of 70$75 \%$ for fine-grained sediments at the seafloor to about $55 \%$ at 100 mbsf. Below that depth, the decrease of porosity vs. depth was nearly linear, reaching a value of $35 \%$ at 810 mbsf. The scattering of data around the trend line was attributed to (a) variations in sediment composition, (b) drilling disturbances, and (c) expanding gas. Drilling disturbance and expanding gas lead to an increase in porosity, water content, and wet-bulk density, whereas the sediment composition can cause a decrease, for instance when organic matter is decomposed.
Grain density (Fig. 26D) varied within the range of 2.65 and $2.85 \mathrm{~g} / \mathrm{cm}^{3}$, values above and below these limits are subject to determination errors.

\section{Compressional Wave Velocity}

Sonic velocity measurements range from $1.55 \mathrm{~km} / \mathrm{s}$ at the mud line to about 1.9 to $2.0 \mathrm{~km} / \mathrm{s}$ at the bottom of Hole $717 \mathrm{C}$. A quite regular increasing trend is shown (Table 11, Fig. 27) with the exception of one high sonic velocity $(4.98 \mathrm{~km} / \mathrm{s})$ measured on a cemented sandstone at 790.3 mbsf. The samples taken below $400-500$ mbsf were highly affected by drilling disturbances: values on the same core and same lithology usually ranged from $1.6 \mathrm{~km} / \mathrm{s}$ in Section 1 to about 1.9 to $2.0 \mathrm{~km} / \mathrm{s}$ in Sections 6 and/or Core Catchers. However, a systematic anisot- 


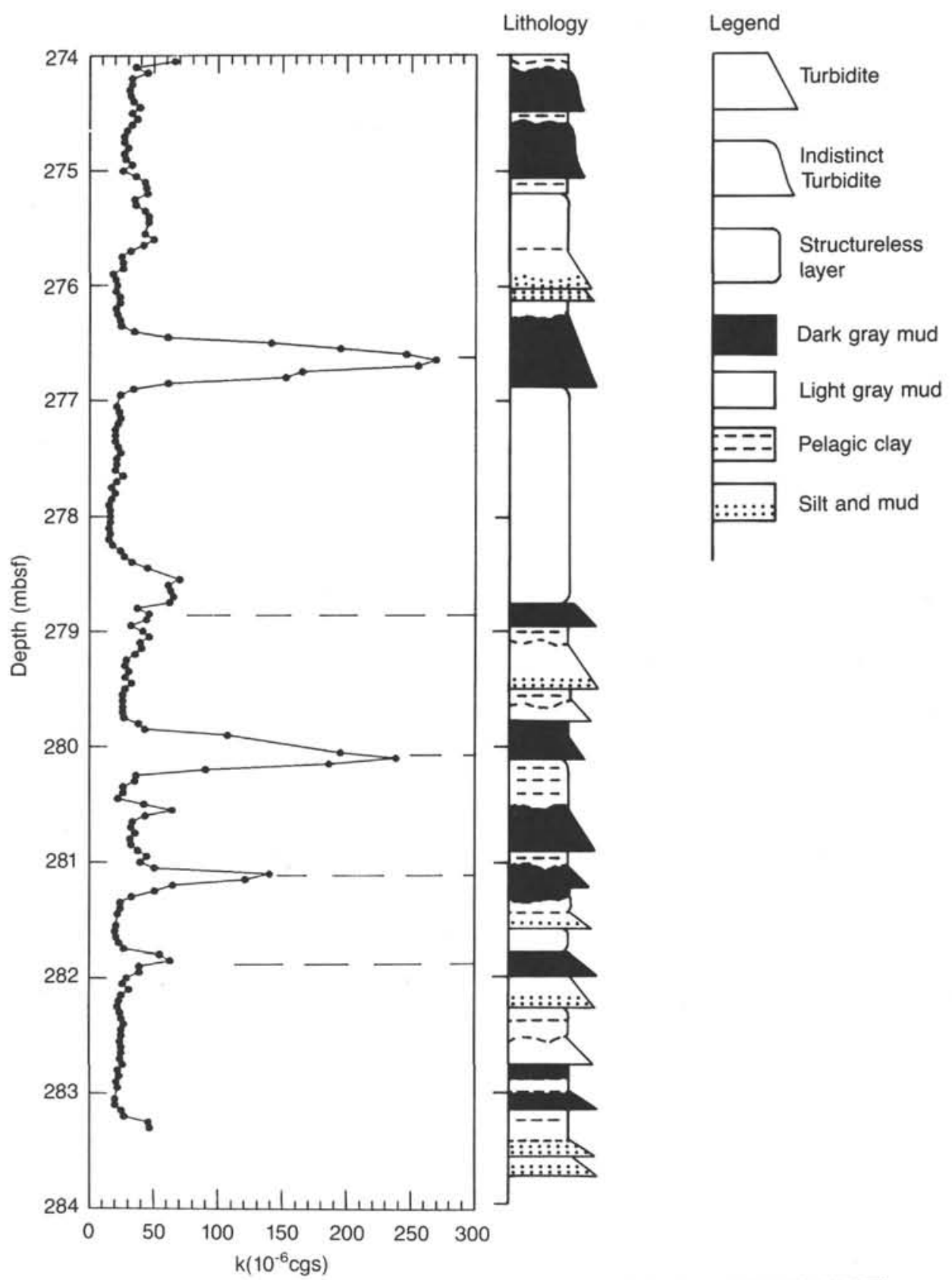

Figure 23. Susceptibility (left) and lithostratigraphy (right) vs. depth for Core 116-717C-33X. These susceptibility peaks are typical of those that display a symmetric shape and are correlated with darkgray mud turbidites. Dashed lines show correlation between turbidites and susceptibility peaks. Plot conventions as in Figure 22.

ropy (up to $8-10 \%$ ) has been observed on relatively well-consolidated samples, the horizontal velocities being always higher than the vertical velocities.

\section{Thermal Conductivity}

Thermal conductivities were used for the evaluation of the heat flow in connection with temperature measurements in Hole $717 \mathrm{C}$ (Table 12, Fig. 28). The thermal conductivity measurements were routinely performed on each section from the mud line to a depth of 395.14 mbsf. Below that depth, drilling disturbances induced a lack of coherence in the measurements. The conductivities varied between 1.41 and $5.26 \times 10^{-3} \mathrm{cal} /\left({ }^{\circ} \mathrm{C} \times\right.$ $\mathrm{cm} \times \mathrm{s}$ ). Four main thermal conductivity units were distinguished: (a) the interval from the mud line to about $150 \mathrm{mbsf}$ was characterized by highly variable data $\left[1.6-5.26 \times 10^{-3} \mathrm{cal} /\right.$ $\left({ }^{\circ} \mathrm{C} \times \mathrm{cm} \times \mathrm{s}\right)$ ] which underscore the heterogeneity of lithologic Units I and II (an average thermal conductivity of about $3.2 \times 10^{-3} \mathrm{cal} /\left({ }^{\circ} \mathrm{C} \times \mathrm{cm} \times \mathrm{s}\right)$ was estimated for this interval using a polynominal least-squares fitting curve); (b) the 150-300 mbsf interval shows more homogeneous values with an average ranging from 2.8 to $3.3 \times 10^{-3} \mathrm{cal} /\left({ }^{\circ} \mathrm{C} \times \mathrm{cm} \times \mathrm{s}\right)$ (this interval corresponds to lithologic Unit III); (c) the 300-360 mbsf interval again shows heterogeneous data which again can be correlated to the more diversified lithologic Subunit IVa; (d) the fine-grained interval 360-395 mbsf shows homogeneous data ranging around $3.2 \times 10^{-3} \mathrm{cal} /\left({ }^{\circ} \mathrm{C} \cdot \mathrm{cm} \cdot \mathrm{s}\right)$.

\section{Undrained Shear Strength}

The measured values of vane-shear-strength are listed in Table 13 and plotted vs. depth in Figure 29. No data were collected 


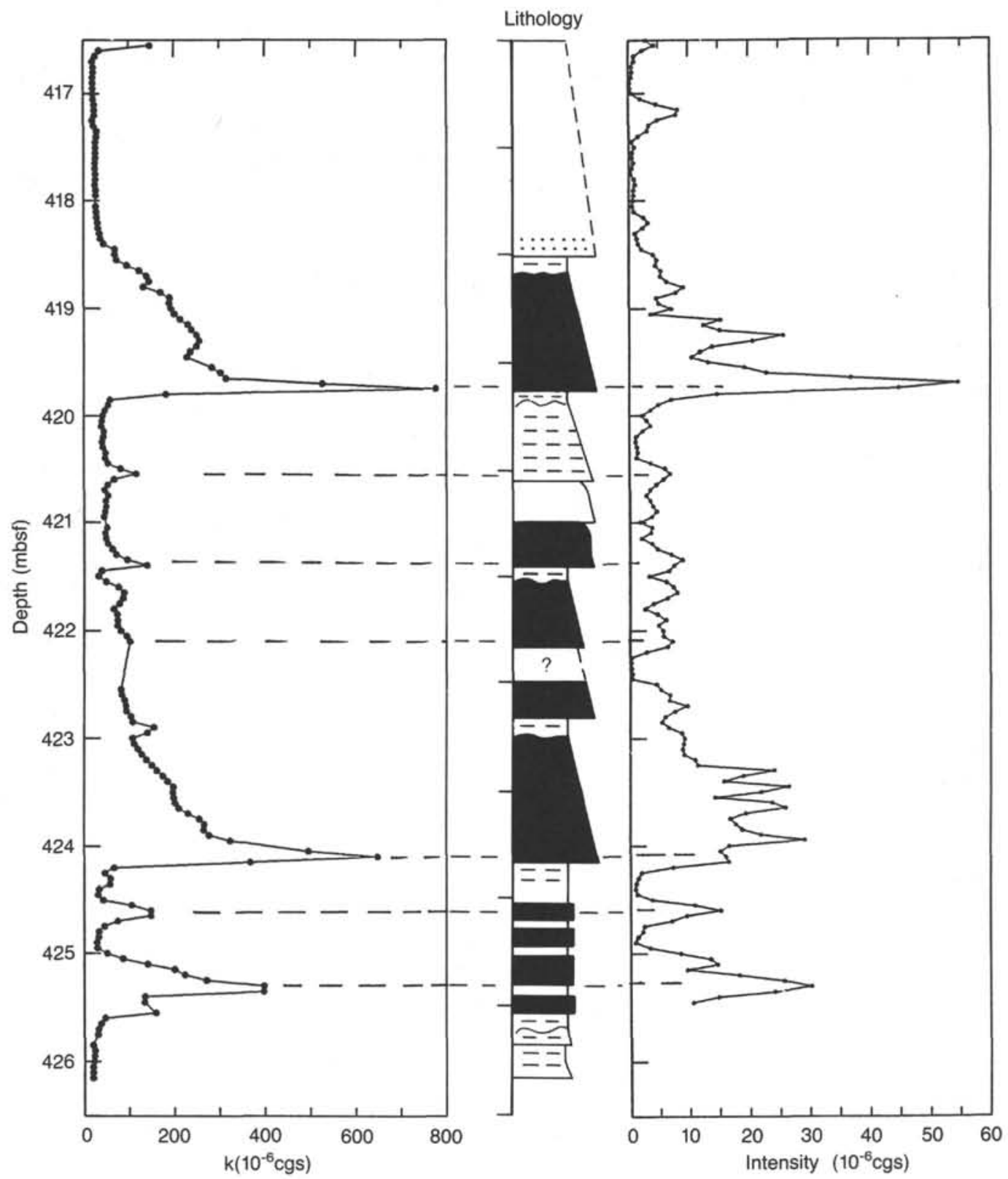

Figure 24. Magnetic susceptibility (left), lithostratigraphy (middle), and remanent magnetic intensity (right) vs. depth for Core 116-717C-48X. The susceptibility peaks are clearly correlated to gray mud turbidites. Several peaks show a graded morphology with a slow rise in susceptibility through the turbidite layer, the highest values at the base, and an abrupt return to lower values below the turbidite. The intensity values were measured after AF demagnetization at $9 \mathrm{mT}$. They show a close correlation with the susceptibility values. Plot conventions and lithostratigraphic legend as in Figure 23.

in the soupy sediments in the top $14 \mathrm{~m}$ of the holes, nor in the more lithified sediments below 350 mbsf.

The values for shear strength in the natural state varied between $9.5 \mathrm{kPa}(20.0 \mathrm{mbsf})$ and $413.8 \mathrm{kPa}(234.4 \mathrm{mbsf})$. Zones of high shear strength were found within the lithologic Unit III between 150 and 300 mbsf. Zones of low shear strength were found within the lithologic Units II and IV between 10-150 and 300340 mbsf. The relative changes in shear strength corresponded with the content of silt and sand.

To estimate the state of consolidation a method described by Skempton (1970) was applied. This method relates undrained shear strength (cu) to effective overburden pressure $\left(P_{o}\right)$. The effective overburden pressure was calculated for every depth inter- val using the equation applied for marine sediments by Richards (1962):

$$
P_{o}=\gamma_{w}-\Delta d(\mathrm{kPa})+P_{i},
$$

where

$P_{o}$ is effective overburden pressure,

$\gamma_{w}$, the buoyant unit weight (wet-bulk density - density of water),

$d$, depth interval from the above sample, and

$P_{i}$, effective overburden pressure of the above sample. 


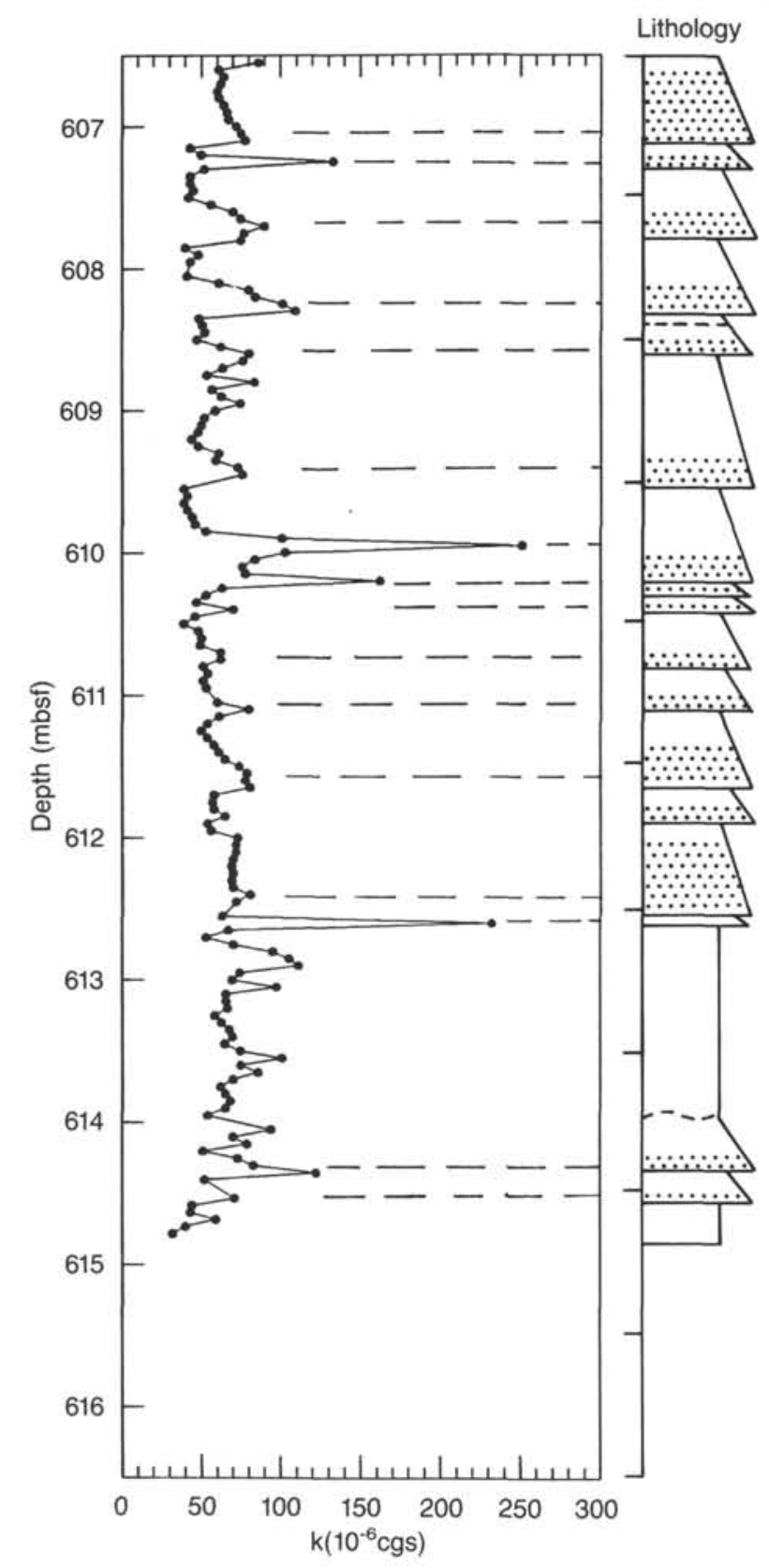

Figure 25. Lithostratigraphy (right) and susceptibility (left) vs. depth for Core $116-717 \mathrm{C}-68 \mathrm{X}$. This core contains numerous silty turbidites which cause peaks in the susceptibility record. Note that most of the peaks correlate with the base of a turbidite layer. Plot conventions and lithostratigraphic legend as in Figure 23.

Skempton (1970) established that the ratio of undrained shear strength to effective overburden pressure in normally consolidated marine sediments ranges between 0.2 and 0.5 . All values of the shear strength/overburden pressure ratio less than 0.2 are assumed to be underconsolidated and those greater than 0.5 are considered to be overconsolidated.

Figure 30 shows the ratio of shear strength to effective overburden pressure plotted versus depth for the sediments of Site $717 \mathrm{C}$. It shows that most of the sediments are slightly underconsolidated, because the ratio of shear strength to effective overburden pressure is lower than 0.2 .

\section{HEAT FLOW}

The region of intraplate deformation in the central Indian Basin is characterized by heat-flow values that show a great deal of variation, but which average higher than theoretically predicted for seafloor of its age (Weissel et al., 1980, Geller et al., 1983). The heat-flow measurements made during the site survey show both of these characteristics (Fig. 31). Measurements ranged from 44 to $166 \mathrm{~mW} / \mathrm{m}^{2}$ with a mean of $83.7 \mathrm{~mW} / \mathrm{m}^{2}$ and a standard deviation of $21.7 \mathrm{~mW} / \mathrm{m}^{2}$. Topographic corrections were not sufficient to account for the presence of such large variations over a short distance, and the large variation appears to result from the influence of water flow.

Site 717 , located at the axis of a synclinal sedimentary structure developed over one of the rotated basement fault blocks, is designed to sample as complete a syn-deformation sequence as possible to serve as a reference section for the other Leg 116 sites. It is thus of interest to know the local heat flow as it is one factor to consider in comparitive studies with Site 718, which is located in an area of locally large heat flow. However, the site survey heat-flow line did not extend as far north as the location of Site 717 (Fig. 31) and therefore heat-flow measurements were carried out as part of the drilling program.

It was initially planned to take measurements using the Von Herzen hydraulic piston corer shoe (APC tool) during piston coring followed by measurements using the Barnes-Uyeda temperature/pore-water/pressure sampler (T-probe) until the sediment became too hard for it to penetrate further. However, on Core 116-717B-2H (Hole 717A missed the mudline and was abandoned), the core barrel broke off in the hole with the result that one of the two APC shoes on board was lost. When the lower section of the APC was bent on Core 116-717C-2H, it was decided to abandon piston coring and to start immediately with the XCB.

Temperature measurements were made in Hole $717 \mathrm{C}$ using the T-probe after Cores 116-717C-8X, -717C-12X, and -717C$16 \mathrm{X}$. Good-quality measurements were obtained for the first and third deployment. No data were obtained for the second deployment because of a failure in the recorder. The temperature records are shown in Figures 32 and 33. The temperatures extrapolated to equilibrium are estimated to be $4.6^{\circ} \mathrm{C}$ [standard error (s.e.) $=0.12^{\circ} \mathrm{J}$ at $74.5 \mathrm{mbsf}$ and $6.9^{\circ} \mathrm{C}\left(\right.$ s.e. $\left.=0.01^{\circ}\right)$ at 131.5 mbsf. A third temperature point can be obtained from the bottom-water temperature that was measured to be $1.7^{\circ} \mathrm{C}$ on both lowerings. The temperatures are plotted against depth in Figure 34. They fall on a straight line that can be fit with a slope of $39.5^{\circ} \mathrm{C} / \mathrm{km}$ (s.e. $\left.=0.04^{\circ}\right)$.

Thermal conductivity measurements from Site 717 are shown in Figure 28. The average value in the upper $130 \mathrm{~m}$ is $3.2 \times$ $10^{-3} \mathrm{cal} /\left(\mathrm{cm} \times{ }^{\circ} \mathrm{C} \times \mathrm{s}\right)$ or $1.34 \mathrm{~W} / \mathrm{m} \times{ }^{\circ} \mathrm{C}$ although there is considerable scatter in the data through the upper $150 \mathrm{~m}$. Accepting that value for the conductivity, the heat flow at Site 717 is calculated to be $52.9 \mathrm{~mW} / \mathrm{m}^{2}$. Magnetic anomaly data ("Site Survey" chapter, Fig. 5) shows that the age of the crust beneath the Leg 116 sites is $78 \mathrm{Ma}$. The theoretical heat flow for $78 \mathrm{Ma}-$ old crust is $53.5 \mathrm{~mW} / \mathrm{m}^{2}$ (Parsons and Sclater, 1977). Although lower than most of the heat-flow measurements taken further south during the site survey, the measurements at Hole $717 \mathrm{C}$ are indistinguishable from the theoretical value. This justifies the use of Hole $717 \mathrm{C}$ as a reference section for the effects of the higher heat flow at Site 718 .

\section{SEISMIC STRATIGRAPHY}

Site 717 was chosen on the basis of single-channel seismic reflection data acquired with an air-gun source during a site sur- 
Table 9. Index properties from Hole 717B.

\begin{tabular}{|c|c|c|c|c|c|c|c|c|}
\hline Core & Sect. & Top & $\begin{array}{l}\text { Bot. } \\
\text { n) }\end{array}$ & $\begin{array}{l}\text { Depth } \\
\text { (mbsf) }\end{array}$ & $\begin{array}{c}\text { Water } \\
\text { content } \\
\text { (\% wet wt.) }\end{array}$ & $\begin{array}{c}\text { Porosity } \\
(\%)\end{array}$ & $\begin{array}{c}\text { Bulk } \\
\text { density } \\
\left(\mathrm{g} / \mathrm{cm}^{3}\right)\end{array}$ & $\begin{array}{c}\text { Grain } \\
\text { density } \\
\left(\mathrm{g} / \mathrm{cm}^{3}\right)\end{array}$ \\
\hline $1 \mathrm{H}$ & 1 & 113 & 118 & 1.13 & 50.68 & 73.02 & 1.50 & 2.66 \\
\hline $1 \mathrm{H}$ & 2 & 60 & 65 & 2.10 & 58.36 & 79.68 & 1.41 & 2.82 \\
\hline $1 \mathrm{H}$ & 2 & 113 & 118 & 2.63 & 53.92 & 76.57 & 1.48 & 2.82 \\
\hline $2 \mathrm{H}$ & 1 & 41 & 45 & 4.41 & 57.17 & 77.58 & 1.42 & 2.61 \\
\hline $2 \mathrm{H}$ & 2 & 90 & 94 & 6.40 & 31.44 & 56.36 & 1.83 & 2.85 \\
\hline
\end{tabular}

vey by R/V Robert D. Conrad on cruise C2706 (Fig. 31). The Conrad seismic line was filtered using a time-varying band-pass filter, and a single-channel migration was employed to attempt to improve the resolution and to precisely locate the fault surfaces. The processing greatly improved the amount of detail that could be observed in the acoustic stratigraphy and removed most of the diffractions associated with the faults. However, discrete fault surfaces could not be determined and the faults appear as somewhat chaotic zones 4 to 8 shot points (190-375 m) wide.

The site chosen was located at time 1359Z, 11 July 1986, on the Conrad seismic record (Fig. 2). An alternative site was also chosen at 1334 UTC, 11 July 1986, $3.7 \mathrm{~km}$ from the prime site, on a parallel seismic line. Because the objective was to obtain a complete reference section, the site was chosen near the northern (lower) end of a tilted fault block at the axis of a synclinal structure developed in the sediments. The site was located approximately $1 \mathrm{~km}$ from a small fault (throw-on basement about $0.2 \mathrm{~s}$ ) separating the target block from the next block to the north. The sediment thickness at the location chosen for the site is $1.96 \mathrm{~s}$.

The seismic records across the fault can be divided into two first-order acoustic units separated by a prominent unconformity labeled "A" on Figures 2 and 35 . The lower unit is consistently 1.15 to $1.35 \mathrm{~s}$ thick and reflectors within it are parallel and follow the basement. The upper sequence has a maximum thickness of about $0.7 \mathrm{~s}$ and thins, mainly through pinch-outs, toward the crest of the rotated blocks. The lower sequence can thus be interpreted as the predeformation section and the upper sequence as the sediments deposited during the deformation. Both sequences exhibit layering, but it is stronger and much more evident in the upper sequence. There is also a difference in the frequency content, with many more high-frequency reflectors in the upper sequence. These differences are not an artifact related to the absorption of energy with depth or to the timevarying filters used in processing since these characteristics can be noted both in the troughs and on the crests of the crustal blocks, while the thickness of the upper unit changes by more than $0.4 \mathrm{~s}$ between the two locations.

Curray and Moore (1971) divided the fan sediments into three major seismic stratigraphic units, termed "W," "Y," and "O," separated by unconformities, which they believed to be younger ("W") and older ("Y") fan sediments and prefan ("O") sediments of unknown origin. The two unconformities were traced on seismic records to sites drilled on DSDP Leg 22. The upper unconformity was penetrated at Site 218 where it was found to correspond to a zone of coarser, more sandy turbidites in the upper Miocene (Moore et al., 1974). The lower unconformity was reached at Site 217 and coincides with an apparent hiatus between Paleocene and middle Eocene (Moore et al., 1974). These authors noted that, on structural highs of the distal fan, the "W" fan deposits lap unconformably onto deformed "Y" sediments. This suggests that unconformity " $\mathrm{A}$ " is equivalent to the upper unconformity of Curray and Moore (1971).
The upper unit in the vicinity of Site 717 records a complex history of the motion on the fault blocks. The history varies somewhat from block to block. It includes an upper highly-layered sequence about $200 \mathrm{~ms}$ thick that is essentially flat lying and has an onlapping relationship with the uplifted sediments on the top of the blocks. This sequence unconformably overlies and truncates reflectors within the underlying sediments (unconformity "B" on Figs. 2 and 35). The syn-deformational sediments between unconformity " $\mathrm{B}$ " and unconformity " $\mathrm{A}$ " are characterized by numerous reflectors which are tilted up to the south (higher side of the tilted block) and which commonly terminate by pinching out against underlying reflectors, resulting in a thinning of this portion of the section toward the south. At the location chosen for Site 717, this sequence has a thickness of about $0.5 \mathrm{~s}$ so that unconformities " $\mathrm{A}$ " and " $\mathrm{B}$ " both appear to become conformable as Site 717 is approached. The goal at Site 717 was to obtain as complete a section as possible, at least through unconformity " $\mathrm{A}$ ", to obtain a sedimentological and paleontological record and to serve as a benchmark section for the other sites where portions of the sequence above unconformity " $A$ " are either missing or condensed.

JOIDES Resolution approached the site from the south and a seismic line was run over the site starting $20 \mathrm{~km}$ away to obtain a line across all three Leg 116 sites. A spar buoy was dropped when we passed the site and the line was continued to verify the position of the hole relative to the fault to the north. JOIDES Resolution then returned to the site and the beacon was dropped $1 \mathrm{~km}$ from the fault at the axis of the syncline. The seismic line obtained during this crossing of the site is shown in Figure 35.

Hole $717 \mathrm{C}$ was drilled to $828.2 \mathrm{mbsf}$. The upper portion of the section consisted of a thin upper layer $(5.5 \mathrm{~m})$ of mud turbidites and pelagic calcareous muds (lithologic Unit I) over a thicker $(145 \mathrm{~m})$ sequence of micaceous silt turbidites (lithologic Unit II). The silts abruptly overlie a sequence of mud turbidites interbedded with pelagic clays (lithologic Unit III) at 151 mbsf. The synthetic seismogram calculated for Site 719 from the well logs shows that the lithologic boundary appears to correspond to Unconformity "B". A similar unit of coarser grained turbidites was encountered at the top of DSDP Site $218,1000 \mathrm{~km}$ to the northeast (Thompson, 1974).

The mud turbidite and pelagic clay sequence (lithologic Units III and IV) extends from 152 to $531.5 \mathrm{mbsf}$. This sequence has two intervals in which silty turbidites are found, at 302.5 to 335 mbsf (lithologic Unit IVa) and at 456 to 465 mbsf (lithologic Unit IVc). A synthetic seismogram constructed at Site 719, where well-log data is available, shows that there is a good correlation between the boundaries between mud turbidite and silty turbidite intervals and prominent reflectors on the seismic line (Fig. 35). The lowest lithologic unit (Unit V) is a sequence of silty turbidites and interbedded pelagic clays that extended from $534 \mathrm{mbsf}$ to the bottom of the hole at $828.2 \mathrm{mbsf}$. The synthetic seismogram for Site 719 shows that the top of this unit does not correspond to unconformity " $\mathrm{A}$ ", but rather to a reflector labeled "Z" on Figure 35. The interval between this reflector and 
Table 10. Index physical properties from Hole 717C.

\begin{tabular}{|c|c|c|c|c|c|c|c|c|}
\hline Core & Sect. & $\begin{array}{l}\text { Top } \\
\text { (c }\end{array}$ & Bot. & $\begin{array}{l}\text { Depth } \\
\text { (mbsf) }\end{array}$ & $\begin{array}{c}\text { Water } \\
\text { content } \\
(\% \text { wet wt.) }\end{array}$ & $\begin{array}{c}\text { Porosity } \\
(\%)\end{array}$ & $\begin{array}{c}\text { Bulk } \\
\text { density } \\
\left(\mathrm{g} / \mathrm{cm}^{3}\right)\end{array}$ & $\begin{array}{l}\text { Grain } \\
\text { density } \\
\left(\mathrm{g} / \mathrm{cm}^{3}\right)\end{array}$ \\
\hline $2 \mathrm{H}$ & 2 & 80 & 82 & 15.80 & 21.72 & 43.37 & 2.03 & 2.80 \\
\hline $4 X$ & 1 & 28 & 30 & 27.28 & 32.34 & 56.06 & 1.81 & 2.71 \\
\hline $5 X$ & 1 & 38 & 40 & 36.88 & 29.87 & 52.75 & 1.85 & 2.66 \\
\hline $5 X$ & 1 & 110 & 113 & 37.60 & 24.28 & 45.90 & 1.96 & 2.68 \\
\hline $6 \mathrm{X}$ & 1 & 63 & 65 & 46.63 & 41.10 & 65.38 & 1.64 & 2.74 \\
\hline $6 \mathrm{X}$ & 1 & 113 & 118 & 47.13 & 39.04 & 63.31 & 1.67 & 2.73 \\
\hline $7 X$ & 1 & 103 & 105 & 56.53 & 35.64 & 59.78 & 1.71 & 2.72 \\
\hline $7 X$ & 2 & 2 & 4 & 57.02 & 21.02 & 41.09 & 2.06 & 2.66 \\
\hline $8 x$ & 2 & 64 & 69 & 67.14 & 40.16 & 64.14 & 1.66 & 2.70 \\
\hline $10 \mathrm{X}$ & 1 & 76 & 81 & 75.26 & 41.27 & 63.54 & 1.72 & 2.51 \\
\hline $10 \mathrm{X}$ & 1 & 113 & 118 & 75.63 & 33.50 & 57.86 & 1.75 & 2.76 \\
\hline $14 X$ & 2 & 19 & 22 & 104.69 & 29.79 & 53.64 & 1.90 & 2.77 \\
\hline $15 \mathrm{X}$ & 1 & 108 & 113 & 113.58 & 28.30 & 52.20 & 1.91 & 2.81 \\
\hline $15 \mathrm{X}$ & 1 & 122 & 127 & 113.72 & 28.84 & 51.87 & 1.91 & 2.70 \\
\hline $16 \mathrm{X}$ & 1 & 72 & 77 & 122.72 & 34.70 & 58.96 & 1.76 & 2.74 \\
\hline $16 x$ & 1 & 109 & 115 & 123.09 & 24.21 & 46.31 & 1.97 & 2.74 \\
\hline $19 \mathrm{X}$ & 1 & 86 & 89 & 141.86 & 30.06 & 53.68 & 1.87 & 2.73 \\
\hline $20 \mathrm{X}$ & 1 & 110 & 113 & 151.60 & 28.18 & 52.04 & 1.91 & 2.81 \\
\hline $20 x$ & 2 & 89 & 92 & 152.89 & 28.91 & 52.58 & 1.82 & 2.77 \\
\hline $20 x$ & 3 & 80 & 85 & 154.30 & 26.40 & 49.13 & 1.90 & 2.73 \\
\hline $20 \mathrm{X}$ & 4 & 21 & 24 & 155.21 & 34.03 & 57.12 & 1.77 & 2.62 \\
\hline $21 X$ & 1 & 107 & 110 & 161.07 & 33.76 & 56.14 & 1.72 & 2.54 \\
\hline $21 X$ & 2 & 75 & 78 & 162.25 & 29.38 & 50.46 & 1.76 & 2.48 \\
\hline $21 X$ & 3 & 70 & 73 & 163.70 & 31.79 & 55.08 & 1.75 & 2.67 \\
\hline $21 X$ & 4 & 66 & 69 & 165.16 & 33.73 & 54.76 & 1.66 & 2.41 \\
\hline $22 X$ & 1 & 19 & 22 & 169.69 & 37.33 & 61.33 & 1.70 & 2.70 \\
\hline $22 \mathrm{X}$ & 4 & 84 & 89 & 174.84 & 33.13 & 55.28 & 1.74 & 2.53 \\
\hline $22 \mathrm{X}$ & 5 & 15 & 20 & 175.65 & 33.45 & 56.53 & 1.73 & 2.62 \\
\hline $23 \mathrm{X}$ & 1 & 113 & 118 & 180.13 & 33.45 & 58.39 & 1.79 & 2.83 \\
\hline $23 \mathrm{X}$ & 3 & 113 & 118 & 183.13 & 34.37 & 57.17 & 1.72 & 2.58 \\
\hline $23 \mathrm{X}$ & 4 & 60 & 65 & 184.10 & 30.79 & 54.66 & 2.17 & 2.75 \\
\hline $23 \mathrm{X}$ & 5 & 113 & 118 & 186.13 & 35.44 & 60.09 & 2.00 & 2.78 \\
\hline $23 \mathrm{X}$ & 6 & 60 & 65 & 187.10 & 39.20 & 60.75 & 1.92 & 2.43 \\
\hline $24 X$ & 1 & 20 & 26 & 188.70 & 35.29 & 58.79 & 1.71 & 2.65 \\
\hline $24 X$ & 2 & 60 & 65 & 190.60 & 32.51 & 56.75 & 1.79 & 2.76 \\
\hline $24 X$ & 3 & 120 & 124 & 192.70 & 34.88 & 59.12 & 1.74 & 2.74 \\
\hline $24 \mathrm{X}$ & 4 & 60 & 65 & 193.60 & 31.54 & 54.53 & 1.80 & 2.64 \\
\hline $24 X$ & 5 & 113 & 117 & 195.63 & 34.09 & 57.36 & 1.72 & 2.64 \\
\hline $24 X$ & 6 & 60 & 65 & 196.60 & 33.37 & 56.86 & 1.76 & 2.67 \\
\hline $25 \mathrm{X}$ & 1 & 114 & 118 & 199.14 & 30.74 & 54.66 & 1.86 & 2.75 \\
\hline $25 \mathrm{X}$ & 2 & 60 & 64 & 200.10 & 33.32 & 56.56 & 1.78 & 2.64 \\
\hline $25 \mathrm{X}$ & 3 & 113 & 117 & 202.13 & 34.71 & 57.19 & 1.73 & 2.54 \\
\hline $25 \mathrm{X}$ & 4 & 60 & 64 & 203.10 & 32.25 & 56.09 & 1.81 & 2.72 \\
\hline $25 \mathrm{X}$ & 5 & 113 & 117 & 205.13 & 33.17 & 56.77 & 1.85 & 2.68 \\
\hline $25 \mathrm{X}$ & 6 & 60 & 64 & 206.12 & 36.34 & 58.25 & 1.71 & 2.47 \\
\hline $26 \mathrm{X}$ & 1 & 70 & 73 & 208.20 & 31.70 & 55.54 & 1.81 & 2.73 \\
\hline $26 x$ & 3 & 116 & 120 & 211.66 & 32.97 & 56.59 & 1.80 & 2.69 \\
\hline $26 x$ & 4 & 45 & 49 & 212.45 & 27.83 & 50.57 & 1.73 & 2.69 \\
\hline $26 \mathrm{X}$ & 5 & 113 & 118 & 214.63 & 34.54 & 58.44 & 1.77 & 2.70 \\
\hline $26 \mathrm{X}$ & 6 & 66 & 70 & 215.66 & 28.49 & 52.38 & 1.76 & 2.80 \\
\hline $26 \mathrm{X}$ & 7 & 10 & 14 & 216.60 & 31.03 & 53.98 & 1.82 & 2.64 \\
\hline $27 \mathrm{X}$ & 1 & 143 & 146 & 218.43 & 34.83 & 59.05 & 1.75 & 2.73 \\
\hline $27 X$ & 2 & 62 & 65 & 219.12 & 36.88 & 61.38 & 1.74 & 2.76 \\
\hline $27 X$ & 3 & 147 & 150 & 221.47 & 30.81 & 54.65 & 1.87 & 2.74 \\
\hline $27 X$ & 4 & 60 & 63 & 222.10 & 34.38 & 57.06 & 1.75 & 2.57 \\
\hline $27 X$ & 5 & 147 & 150 & 224.47 & 28.32 & 50.56 & 1.88 & 2.62 \\
\hline $27 X$ & 6 & 65 & 68 & 225.15 & 36.99 & 61.72 & 1.71 & 2.78 \\
\hline $28 \mathrm{X}$ & 1 & 128 & 132 & 227.78 & 35.14 & 58.48 & 1.76 & 2.63 \\
\hline $28 \mathrm{X}$ & 2 & 63 & 67 & 228.63 & 33.43 & 56.62 & 1.78 & 2.63 \\
\hline $28 \mathrm{X}$ & 3 & 147 & 150 & 230.97 & 28.91 & 51.52 & 1.87 & 2.65 \\
\hline $28 \mathrm{X}$ & 4 & 63 & 67 & 231.63 & 32.42 & 55.33 & 1.81 & 2.62 \\
\hline $28 \mathrm{X}$ & 5 & 11 & 15 & 232.61 & 28.83 & 52.79 & 1.90 & 2.80 \\
\hline $29 \mathrm{X}$ & 1 & 142 & 145 & 237.42 & 34.35 & 58.83 & 1.78 & 2.77 \\
\hline $29 X$ & 2 & 63 & 66 & 238.13 & 38.26 & 62.57 & 1.71 & 2.73 \\
\hline $29 \mathrm{X}$ & 3 & 131 & 134 & 240.31 & 33.46 & 56.53 & 1.75 & 2.62 \\
\hline $29 X$ & 4 & 62 & 65 & 241.12 & 31.83 & 57.16 & 1.90 & 2.90 \\
\hline $29 X$ & 5 & 141 & 143 & 243.41 & 31.62 & 54.46 & 1.83 & 2.62 \\
\hline $29 X$ & 6 & 61 & 64 & 244.11 & 34.92 & 59.71 & 1.80 & 2.80 \\
\hline $30 \mathrm{X}$ & 1 & 118 & 123 & 246.68 & 32.33 & 55.10 & 1.78 & 2.60 \\
\hline $30 \mathrm{x}$ & 2 & 60 & 64 & 247.60 & 32.10 & 56.26 & 1.85 & 2.76 \\
\hline $30 x$ & 4 & 61 & 64 & 250.61 & 31.77 & 55.23 & 1.84 & 2.69 \\
\hline $30 \mathrm{x}$ & 5 & 112 & 116 & 252.62 & 35.21 & 59.56 & 1.75 & 2.75 \\
\hline $30 x$ & 6 & 63 & 67 & 253.63 & 30.06 & 54.37 & 1.90 & 2.81 \\
\hline $31 X$ & 1 & 63 & 67 & 255.63 & 26.73 & 48.24 & 1.47 & 2.59 \\
\hline $31 X$ & 2 & 113 & 117 & 257.63 & 29.46 & 53.41 & 1.87 & 2.78 \\
\hline $31 X$ & 3 & 20 & 24 & 258.20 & 29.23 & 53.55 & 1.89 & 2.83 \\
\hline $32 \mathrm{X}$ & 1 & 117 & 121 & 265.67 & 26.24 & 48.41 & 1.91 & 2.68 \\
\hline $33 \mathrm{X}$ & 2 & 64 & 68 & 276.14 & 29.33 & 53.40 & 1.89 & 2.80 \\
\hline
\end{tabular}


Table 10 (continued).

\begin{tabular}{|c|c|c|c|c|c|c|c|c|}
\hline Core & Sect. & Top & $\begin{array}{l}\text { Bot. } \\
\text { a) }\end{array}$ & $\begin{array}{l}\text { Depth } \\
\text { (mbsf) }\end{array}$ & $\begin{array}{c}\text { Water } \\
\text { content } \\
\text { ( } \% \text { wet wt.) }\end{array}$ & $\begin{array}{c}\text { Porosity } \\
\text { (\%) }\end{array}$ & $\begin{array}{c}\text { Bulk } \\
\text { density } \\
\left(\mathrm{g} / \mathrm{cm}^{3}\right)\end{array}$ & $\begin{array}{c}\text { Grain } \\
\text { density } \\
\left(\mathrm{g} / \mathrm{cm}^{3}\right)\end{array}$ \\
\hline $33 x$ & 3 & 113 & 117 & 278.13 & 34.28 & 57.95 & 1.76 & 2.68 \\
\hline $33 x$ & 4 & 61 & 65 & 279.11 & 31.24 & 54.94 & 1.81 & 2.72 \\
\hline $33 x$ & 5 & 113 & 117 & 281.13 & 32.63 & 56.85 & 1.80 & 2.76 \\
\hline $33 \mathrm{X}$ & 6 & 60 & 64 & 282.10 & 26.44 & 49.69 & 1.95 & 2.79 \\
\hline $34 \mathrm{X}$ & 1 & 118 & 123 & 284.68 & 28.92 & 52.77 & 1.93 & 2.79 \\
\hline $34 X$ & 2 & 90 & 94 & 285.90 & 33.70 & 57.74 & 1.80 & 2.72 \\
\hline $34 X$ & 3 & 113 & 118 & 287.63 & 34.17 & 57.91 & 1.77 & 2.69 \\
\hline $35 \mathrm{X}$ & 1 & 113 & 117 & 294.13 & 33.54 & 56.20 & 1.76 & 2.58 \\
\hline $35 X$ & 2 & 90 & 94 & 295.40 & 27.19 & 50.62 & 1.91 & 2.78 \\
\hline $35 X$ & 3 & 113 & 118 & 297.13 & 34.17 & 57.91 & 1.77 & 2.69 \\
\hline $35 \mathrm{X}$ & 4 & 60 & 64 & 298.10 & 29.47 & 52.77 & 1.86 & 2.71 \\
\hline $35 \mathrm{X}$ & 5 & 116 & 119 & 300.16 & 36.89 & 60.37 & 1.72 & 2.64 \\
\hline $35 \mathrm{X}$ & 6 & 60 & 64 & 301.10 & 32.10 & 56.74 & 1.88 & 2.81 \\
\hline $36 \mathrm{X}$ & 1 & 116 & 119 & 303.66 & 37.01 & 60.49 & 1.72 & 2.64 \\
\hline $36 \mathrm{X}$ & 2 & 63 & 68 & 304.63 & 29.14 & 53.63 & 2.04 & 2.85 \\
\hline $36 \mathrm{X}$ & 3 & 120 & 124 & 306.70 & 26.76 & 49.52 & 1.80 & 2.72 \\
\hline $36 \mathrm{X}$ & 4 & 60 & 64 & 307.60 & 25.24 & 47.04 & 1.95 & 2.67 \\
\hline $36 \mathrm{X}$ & 5 & 124 & 128 & 309.74 & 25.46 & 49.19 & 1.94 & 2.88 \\
\hline $36 x$ & 6 & 61 & 65 & 310.61 & 31.39 & 55.39 & 1.84 & 2.75 \\
\hline $37 \mathrm{X}$ & 2 & 136 & 139 & 314.86 & 28.44 & 52.74 & 1.91 & 2.85 \\
\hline $37 \mathrm{X}$ & 3 & 72 & 75 & 315.72 & 24.01 & 45.92 & 2.06 & 2.73 \\
\hline $38 \mathrm{X}$ & 2 & 88 & 90 & 323.88 & 27.45 & 50.04 & 1.89 & 2.69 \\
\hline $38 \mathrm{X}$ & 3 & 56 & 59 & 325.06 & 25.75 & 48.57 & 1.92 & 2.76 \\
\hline $39 \mathrm{X}$ & 1 & 38 & 41 & 331.38 & 22.61 & 44.07 & 2.03 & 2.74 \\
\hline $40 X$ & 1 & 110 & 114 & 341.60 & 23.49 & 46.04 & 1.98 & 2.82 \\
\hline $40 x$ & 2 & 55 & 59 & 342.55 & 47.05 & 70.00 & 2.29 & 2.65 \\
\hline $40 x$ & 4 & 32 & 36 & 345.32 & 30.20 & 54.11 & 1.82 & 2.76 \\
\hline $40 \mathrm{X}$ & 5 & 115 & 119 & 347.65 & 31.06 & 54.30 & 1.81 & 2.67 \\
\hline $40 X$ & 6 & 47 & 50 & 348.47 & 31.15 & 51.85 & 1.82 & 2.41 \\
\hline $41 X$ & 1 & 40 & 42 & 350.40 & 32.22 & 55.63 & 1.79 & 2.67 \\
\hline $42 \mathrm{X}$ & 2 & 106 & 109 & 362.06 & 25.19 & 48.35 & 1.96 & 2.82 \\
\hline $42 X$ & 3 & 72 & 75 & 363.22 & 23.99 & 45.92 & 1.96 & 2.73 \\
\hline $42 X$ & 4 & 87 & 90 & 364.87 & 20.77 & 42.23 & 2.08 & 2.83 \\
\hline $42 \mathrm{X}$ & 5 & 73 & 76 & 366.23 & 24.22 & 46.40 & 1.99 & 2.75 \\
\hline $42 x$ & 6 & 104 & 107 & 368.04 & 25.08 & 46.99 & 1.95 & 2.69 \\
\hline $43 x$ & 1 & 62 & 64 & 369.62 & 32.29 & 55.97 & 1.80 & 2.70 \\
\hline $43 X$ & 3 & 59 & 62 & 372.59 & 29.40 & 52.81 & 1.82 & 2.72 \\
\hline $43 X$ & 3 & 59 & 62 & 372.59 & 24.14 & 46.33 & 1.94 & 2.75 \\
\hline $43 \mathrm{X}$ & 4 & 110 & 113 & 374.60 & 29.95 & 52.83 & 1.83 & 2.66 \\
\hline $43 X$ & 5 & 59 & 63 & 375.59 & 31.62 & 54.83 & 1.79 & 2.66 \\
\hline $43 X$ & 6 & 110 & 113 & 377.60 & 23.53 & 45.88 & 2.04 & 2.80 \\
\hline $44 X$ & 1 & 109 & 111 & 379.59 & 32.73 & 56.16 & 1.78 & 2.67 \\
\hline $44 X$ & 2 & 60 & 62 & 380.60 & 30.00 & 53.65 & 1.82 & 2.74 \\
\hline $44 X$ & 3 & 113 & 115 & 382.63 & 31.16 & 55.23 & 1.83 & 2.76 \\
\hline $44 X$ & 4 & 60 & 62 & 383.60 & 28.02 & 50.94 & 1.71 & 2.71 \\
\hline $44 X$ & 5 & 113 & 115 & 385.63 & 24.42 & 47.23 & 1.97 & 2.81 \\
\hline $44 X$ & 6 & 60 & 62 & 386.60 & 25.02 & 47.78 & 1.96 & 2.78 \\
\hline $45 \mathrm{X}$ & 1 & 113 & 115 & 389.13 & 26.83 & 49.78 & 1.91 & 2.74 \\
\hline $45 \mathrm{X}$ & 1 & 113 & 115 & 389.13 & 22.61 & 44.31 & 2.00 & 2.76 \\
\hline $45 \mathrm{X}$ & 2 & 60 & 62 & 390.10 & 27.84 & 50.76 & 1.88 & 2.71 \\
\hline $45 \mathrm{X}$ & 3 & 113 & 115 & 392.13 & 24.46 & 45.95 & 1.94 & 2.66 \\
\hline $45 \mathrm{X}$ & 4 & 60 & 62 & 393.10 & 25.06 & 47.59 & 1.97 & 2.76 \\
\hline $45 \mathrm{X}$ & 6 & 59 & 61 & 396.09 & 22.08 & 43.42 & 2.00 & 2.75 \\
\hline $46 x$ & 2 & 90 & 92 & 399.90 & 27.29 & 49.99 & 1.89 & 2.70 \\
\hline $46 x$ & 3 & 112 & 114 & 401.62 & 25.17 & 47.44 & 1.94 & 2.72 \\
\hline $46 x$ & 4 & 59 & 61 & 402.59 & 27.88 & 50.65 & 1.98 & 2.69 \\
\hline $47 \mathrm{X}$ & 2 & 60 & 62 & 409.10 & 29.60 & 52.90 & 1.84 & 2.71 \\
\hline $47 X$ & 3 & 10 & 12 & 410.10 & 22.53 & 44.14 & 1.98 & 2.76 \\
\hline $48 \mathrm{X}$ & 2 & 114 & 118 & 419.14 & 29.16 & 52.27 & 1.86 & 2.70 \\
\hline $48 \mathrm{X}$ & 4 & 92 & 96 & 421.92 & 26.52 & 48.53 & 1.91 & 2.65 \\
\hline $48 \mathrm{X}$ & 6 & 41 & 46 & 424.41 & 23.77 & 46.40 & 2.00 & 2.82 \\
\hline $49 \mathrm{X}$ & 1 & 146 & 150 & 427.46 & 33.04 & 56.52 & 1.75 & 2.67 \\
\hline $49 x$ & 2 & 61 & 64 & 428.11 & 30.95 & 55.23 & 1.81 & 2.79 \\
\hline $49 X$ & 4 & 63 & 64 & 431.13 & 26.20 & 49.12 & 1.94 & 2.76 \\
\hline $50 \mathrm{X}$ & 2 & 59 & 61 & 437.59 & 29.25 & 53.51 & 1.87 & 2.82 \\
\hline $50 \mathrm{x}$ & 4 & 59 & 61 & 440.59 & 30.86 & 55.27 & 1.85 & 2.81 \\
\hline $50 X$ & 6 & 26 & 28 & 443.26 & 25.65 & 48.12 & 1.93 & 2.73 \\
\hline $51 X$ & 2 & 12 & 14 & 446.62 & 23.97 & 46.16 & 1.99 & 2.76 \\
\hline $51 X$ & 3 & 93 & 95 & 448.93 & 27.63 & 51.34 & 1.90 & 2.80 \\
\hline $51 X$ & 4 & 41 & 43 & 449.91 & 24.44 & 47.10 & 1.99 & 2.79 \\
\hline $52 \mathrm{X}$ & 1 & 104 & 107 & 455.54 & 27.32 & 50.71 & 1.91 & 2.78 \\
\hline $52 \mathrm{X}$ & 2 & 134 & 137 & 457.34 & 25.23 & 47.88 & 1.95 & 2.76 \\
\hline $53 \mathrm{X}$ & 2 & 56 & 60 & 466.06 & 20.74 & 42.25 & 2.13 & 2.84 \\
\hline $53 \mathrm{X}$ & 4 & 138 & 142 & 469.88 & 22.62 & 44.80 & 2.02 & 2.82 \\
\hline $53 \mathrm{X}$ & 5 & 63 & 65 & 470.63 & 21.04 & 43.01 & 2.06 & 2.88 \\
\hline $53 \mathrm{X}$ & 6 & 120 & 122 & 472.70 & 27.85 & 51.56 & 1.92 & 2.80 \\
\hline $54 X$ & 1 & 113 & 118 & 474.63 & 33.33 & 57.14 & 1.76 & 2.70 \\
\hline
\end{tabular}


Table 10 (continued).

\begin{tabular}{|c|c|c|c|c|c|c|c|c|}
\hline Core & Sect. & Top & $\begin{array}{l}\text { Bot. } \\
\text { n) }\end{array}$ & $\begin{array}{l}\text { Depth } \\
\text { (mbsf) }\end{array}$ & $\begin{array}{c}\text { Water } \\
\text { content } \\
(\% \text { wet wt.) }\end{array}$ & $\begin{array}{c}\text { Porosity } \\
(\%)\end{array}$ & $\begin{array}{c}\text { Bulk } \\
\text { density } \\
\left(\mathrm{g} / \mathrm{cm}^{3}\right)\end{array}$ & $\begin{array}{c}\text { Grain } \\
\text { density } \\
\left(\mathrm{g} / \mathrm{cm}^{3}\right)\end{array}$ \\
\hline $54 X$ & 3 & 113 & 118 & 477.63 & 23.58 & 46.01 & 2.00 & 2.80 \\
\hline $54 \mathrm{X}$ & 4 & 47 & 49 & 478.47 & 23.07 & 44.69 & 2.00 & 2.74 \\
\hline $54 X$ & 5 & 111 & 116 & 480.61 & 21.64 & 43.35 & 2.00 & 2.81 \\
\hline $54 \mathrm{X}$ & 6 & 142 & 144 & 482.42 & 29.81 & 53.01 & 1.87 & 2.69 \\
\hline $54 X$ & 7 & 10 & 12 & 482.60 & 24.51 & 47.83 & 2.00 & 2.87 \\
\hline $55 \mathrm{X}$ & 1 & 57 & 59 & 483.57 & 25.71 & 48.96 & 1.95 & 2.81 \\
\hline $55 \mathrm{X}$ & 2 & 73 & 75 & 485.23 & 28.50 & 50.69 & 1.89 & 2.61 \\
\hline $55 \mathrm{X}$ & 3 & 47 & 50 & 486.47 & 20.57 & 47.03 & 2.06 & 3.48 \\
\hline $55 \mathrm{X}$ & C & 34 & 37 & 486.95 & 27.90 & 50.37 & 1.90 & 2.66 \\
\hline $56 \mathrm{X}$ & 1 & 68 & 70 & 493.18 & 26.16 & 49.09 & 1.94 & 2.76 \\
\hline $56 \mathrm{X}$ & 4 & 123 & 125 & 498.23 & 24.04 & 46.58 & 2.04 & 2.80 \\
\hline $56 \mathrm{X}$ & 6 & 126 & 129 & 501.26 & 26.43 & 49.28 & 1.95 & 2.74 \\
\hline $56 \mathrm{X}$ & 7 & 13 & 15 & 501.63 & 24.39 & 46.37 & 1.95 & 2.72 \\
\hline $57 X$ & 1 & 75 & 77 & 502.75 & 24.93 & 48.15 & 1.97 & 2.84 \\
\hline $57 \mathrm{X}$ & 3 & 65 & 66 & 505.65 & 25.83 & 48.63 & 1.95 & 2.76 \\
\hline $57 \mathrm{X}$ & 5 & 88 & 91 & 508.88 & 26.89 & 49.84 & 2.02 & 2.74 \\
\hline $58 \mathrm{X}$ & 1 & 67 & 69 & 512.17 & 28.08 & 50.62 & 1.92 & 2.66 \\
\hline $58 \mathrm{X}$ & 2 & 64 & 66 & 513.64 & 31.87 & 51.70 & 1.82 & 2.32 \\
\hline $58 \mathrm{X}$ & 5 & 40 & 42 & 517.91 & 26.83 & 50.43 & 1.96 & 2.81 \\
\hline $59 \mathrm{X}$ & 1 & 12 & 16 & 521.12 & 24.51 & 47.42 & 1.95 & 2.82 \\
\hline $59 \mathrm{X}$ & 2 & 22 & 26 & 522.72 & 23.71 & 45.92 & 1.99 & 2.77 \\
\hline $59 \mathrm{X}$ & 3 & 92 & 97 & 524.92 & 25.09 & 48.40 & 2.00 & 2.84 \\
\hline $59 \mathrm{X}$ & 4 & 45 & 47 & 525.95 & 24.58 & 48.16 & 2.01 & 2.89 \\
\hline $59 \mathrm{X}$ & 6 & 139 & 144 & 529.89 & 28.45 & 52.36 & 1.89 & 2.80 \\
\hline $60 x$ & 1 & 114 & 118 & 531.64 & 23.83 & 46.38 & 1.98 & 2.81 \\
\hline $60 x$ & 2 & 62 & 66 & 532.62 & 23.66 & 46.24 & 1.99 & 2.82 \\
\hline $61 X$ & 1 & 22 & 26 & 540.22 & 21.56 & 43.49 & 2.06 & 2.84 \\
\hline $61 X$ & 2 & 128 & 132 & 542.78 & 18.90 & 39.06 & 2.15 & 2.79 \\
\hline $63 x$ & 1 & 134 & 136 & 560.34 & 25.57 & 48.80 & 1.95 & 2.82 \\
\hline $63 x$ & 2 & 50 & 53 & 561.00 & 23.50 & 46.20 & 2.01 & 2.84 \\
\hline $64 X$ & 1 & 141 & 145 & 569.91 & 22.06 & 44.08 & 2.04 & 2.83 \\
\hline $64 X$ & 2 & 38 & 42 & 570.38 & 26.11 & 49.70 & 1.94 & 2.84 \\
\hline $65 X$ & 2 & 76 & 78 & 580.26 & 22.91 & 45.49 & 2.03 & 2.85 \\
\hline $65 X$ & 3 & 41 & 44 & 581.41 & 25.19 & 48.43 & 1.95 & 2.83 \\
\hline $65 X$ & 6 & 21 & 23 & 585.71 & 23.00 & 45.74 & 2.01 & 2.86 \\
\hline $65 x$ & C & 17 & 20 & 586.18 & 24.59 & 46.99 & 1.96 & 2.76 \\
\hline $66 x$ & 1 & 115 & 117 & 588.65 & 22.47 & 44.71 & 2.02 & 2.83 \\
\hline $66 \mathrm{X}$ & 2 & 14 & 16 & 589.14 & 22.07 & 43.99 & 2.08 & 2.82 \\
\hline $66 x$ & 3 & 83 & 86 & 591.33 & 22.54 & 44.48 & 2.03 & 2.80 \\
\hline $66 x$ & 4 & 21 & 23 & 592.21 & 52.99 & 65.91 & 2.04 & 1.72 \\
\hline $68 \mathrm{X}$ & 1 & 88 & 91 & 607.38 & 24.30 & 47.47 & 1.97 & 2.86 \\
\hline $68 \mathrm{X}$ & 2 & 106 & 108 & 609.06 & 23.20 & 45.90 & 2.02 & 2.85 \\
\hline $68 \mathrm{X}$ & 3 & 96 & 98 & 610.46 & 23.95 & 46.86 & 1.98 & 2.84 \\
\hline $68 \mathrm{X}$ & 5 & 70 & 72 & 613.20 & 22.40 & 44.01 & 2.00 & 2.76 \\
\hline $69 \mathrm{X}$ & 1 & 115 & 117 & 617.15 & 22.68 & 44.68 & 2.01 & 2.80 \\
\hline $69 \mathrm{X}$ & 2 & 33 & 36 & 617.83 & 22.03 & 44.27 & 2.04 & 2.85 \\
\hline $69 \mathrm{X}$ & 3 & 63 & 66 & 619.63 & 21.96 & 44.19 & 2.11 & 2.86 \\
\hline $70 x$ & 2 & 65 & 67 & 627.65 & 23.78 & 46.55 & 2.37 & 2.83 \\
\hline $70 x$ & 3 & 85 & 87 & 629.35 & 21.74 & 43.43 & 2.02 & 2.80 \\
\hline $70 x$ & 4 & 58 & 60 & 630.58 & 19.77 & 40.62 & 2.17 & 2.82 \\
\hline $70 x$ & 4 & 58 & 60 & 630.58 & 19.77 & 40.62 & 2.17 & 2.82 \\
\hline $70 x$ & 6 & 70 & 72 & 633.70 & 20.69 & 41.34 & 2.06 & 2.74 \\
\hline $70 x$ & $\mathrm{C}$ & 6 & 8 & 634.56 & 20.53 & 41.33 & 2.13 & 2.77 \\
\hline $71 x$ & 1 & 50 & 53 & 635.50 & 21.13 & 42.52 & 2.03 & 2.80 \\
\hline $71 X$ & 2 & 49 & 51 & 636.99 & 20.36 & 41.65 & 2.07 & 2.83 \\
\hline $71 X$ & 3 & 42 & 46 & 638.42 & 18.37 & 38.98 & 2.10 & 2.88 \\
\hline $71 X$ & 4 & 15 & 17 & 639.65 & 21.27 & 42.60 & 2.03 & 2.79 \\
\hline $71 x$ & C & 14 & 16 & 642.85 & 20.81 & 42.35 & 2.13 & 2.84 \\
\hline $72 X$ & 1 & 83 & 85 & 645.33 & 20.45 & 40.96 & 2.09 & 2.74 \\
\hline $72 X$ & 2 & 84 & 86 & 646.84 & 21.89 & 43.75 & 2.01 & 2.82 \\
\hline $73 x$ & 2 & 61 & 63 & 656.11 & 20.43 & 41.33 & 2.07 & 2.79 \\
\hline $74 \mathrm{X}$ & 1 & 112 & 115 & 664.62 & 21.13 & 42.81 & 2.04 & 2.84 \\
\hline $75 \mathrm{X}$ & 1 & 103 & 108 & 674.03 & 20.44 & 41.06 & 2.12 & 2.75 \\
\hline $75 \mathrm{X}$ & 2 & 78 & 83 & 675.28 & 20.94 & 41.98 & 2.08 & 2.77 \\
\hline $75 x$ & 3 & 105 & 110 & 677.05 & 18.75 & 39.11 & 2.13 & 2.83 \\
\hline $75 X$ & 4 & 65 & 70 & 678.15 & 20.31 & 41.33 & 2.10 & 2.81 \\
\hline $76 x$ & 1 & 38 & 43 & 682.88 & 14.07 & 30.97 & 2.28 & 2.78 \\
\hline $76 x$ & 2 & 90 & 97 & 684.90 & 21.38 & 42.92 & 2.06 & 2.81 \\
\hline $76 x$ & 3 & 121 & 126 & 686.71 & 15.16 & 32.31 & 2.22 & 2.71 \\
\hline $76 x$ & 4 & 46 & 51 & 687.46 & 18.03 & 37.91 & 2.21 & 2.82 \\
\hline $77 X$ & 1 & 126 & 129 & 693.26 & 18.09 & 37.76 & 2.15 & 2.79 \\
\hline $77 \mathrm{X}$ & 2 & 36 & 40 & 693.86 & 19.24 & 39.09 & 2.13 & 2.74 \\
\hline $77 \mathrm{X}$ & 3 & 123 & 126 & 696.23 & 22.14 & 43.75 & 2.03 & 2.78 \\
\hline $77 \mathrm{X}$ & 4 & 23 & 27 & 696.73 & 18.81 & 38.70 & 2.09 & 2.77 \\
\hline $77 \mathrm{X}$ & 5 & 118 & 123 & 699.18 & 19.98 & 41.06 & 2.09 & 2.83 \\
\hline $77 \mathrm{X}$ & 6 & 40 & 44 & 699.90 & 19.56 & 39.33 & 2.05 & 2.71 \\
\hline $78 \mathrm{X}$ & 1 & 121 & 123 & 702.71 & 21.09 & 42.68 & 2.10 & 2.83 \\
\hline
\end{tabular}


Table 10 (continued).

\begin{tabular}{|c|c|c|c|c|c|c|c|c|}
\hline Core & Sect. & Top & Bot. & $\begin{array}{l}\text { Depth } \\
\text { (mbsf) }\end{array}$ & $\begin{array}{c}\text { Water } \\
\text { content } \\
\text { (\% wet wt.) }\end{array}$ & $\begin{array}{c}\text { Porosity } \\
(\%)\end{array}$ & $\begin{array}{c}\text { Bulk } \\
\text { density } \\
\left(\mathrm{g} / \mathrm{cm}^{3}\right)\end{array}$ & $\begin{array}{c}\text { Grain } \\
\text { density } \\
\left(\mathrm{g} / \mathrm{cm}^{3}\right)\end{array}$ \\
\hline $78 \mathrm{X}$ & 2 & 74 & 77 & 703.74 & 21.18 & 41.96 & 2.06 & 2.73 \\
\hline $78 \mathrm{X}$ & 3 & 58 & 61 & 705.08 & 19.80 & 39.77 & 2.09 & 2.72 \\
\hline $78 X$ & 4 & 109 & 112 & 707.09 & 20.48 & 40.56 & 2.09 & 2.69 \\
\hline $78 X$ & 5 & 114 & 117 & 708.64 & 20.37 & 41.61 & 2.09 & 2.83 \\
\hline $78 \mathrm{X}$ & 6 & 143 & 146 & 710.43 & 19.81 & 40.86 & 1.86 & 2.84 \\
\hline $79 X$ & 1 & 116 & 118 & 712.16 & 19.76 & 40.09 & 2.12 & 2.76 \\
\hline $79 X$ & 2 & 7 & 9 & 712.57 & 20.26 & 41.32 & 2.11 & 2.81 \\
\hline $79 X$ & 3 & 110 & 114 & 715.10 & 21.31 & 43.07 & 2.09 & 2.84 \\
\hline $79 X$ & 4 & 62 & 64 & 716.12 & 21.02 & 41.97 & 2.16 & 2.76 \\
\hline $79 X$ & 5 & 134 & 136 & 718.34 & 20.57 & 41.89 & 2.13 & 2.83 \\
\hline $79 X$ & 6 & 24 & 26 & 718.74 & 21.24 & 42.90 & 2.12 & 2.83 \\
\hline $80 X$ & 1 & 109 & 111 & 721.59 & 19.53 & 39.96 & 2.15 & 2.79 \\
\hline $80 X$ & 2 & 110 & 112 & 723.10 & 20.38 & 41.75 & 2.13 & 2.84 \\
\hline $80 X$ & 3 & 105 & 108 & 724.55 & 22.19 & 44.20 & 2.07 & 2.82 \\
\hline $83 X$ & 1 & 65 & 69 & 749.65 & 17.61 & 38.09 & 2.26 & 2.93 \\
\hline $84 X$ & 1 & 2 & 4 & 758.52 & 26.71 & 48.94 & 2.07 & 2.67 \\
\hline $84 X$ & 1 & 37 & 40 & 758.87 & 20.27 & 41.46 & 2.07 & 2.83 \\
\hline $84 X$ & 2 & 26 & 28 & 760.26 & 18.77 & 39.18 & 2.18 & 2.83 \\
\hline $84 X$ & 3 & 23 & 25 & 761.73 & 20.27 & 41.82 & 2.16 & 2.87 \\
\hline $84 X$ & C & 11 & 13 & 762.86 & 19.30 & 39.91 & 2.14 & 2.82 \\
\hline $85 X$ & 1 & 80 & 83 & 768.80 & 18.99 & 39.20 & 2.15 & 2.79 \\
\hline $85 X$ & 2 & 112 & 115 & 770.62 & 18.58 & 39.10 & 2.17 & 2.86 \\
\hline $85 X$ & 3 & 117 & 120 & 772.17 & 18.61 & 39.32 & 2.22 & 2.88 \\
\hline $85 X$ & 4 & 98 & 101 & 773.48 & 20.16 & 40.94 & 2.11 & 2.79 \\
\hline $85 X$ & 5 & 123 & 125 & 775.23 & 21.04 & 42.76 & 2.11 & 2.85 \\
\hline $85 X$ & 6 & 105 & 108 & 776.55 & 17.89 & 38.90 & 2.13 & 2.97 \\
\hline $87 X$ & 1 & 134 & 138 & 788.34 & 19.07 & 39.54 & 2.20 & 2.82 \\
\hline $87 X$ & 2 & 87 & 91 & 789.37 & 24.22 & 47.02 & 2.04 & 2.82 \\
\hline $89 X$ & 1 & 43 & 45 & 806.43 & 20.39 & 41.39 & 2.10 & 2.80 \\
\hline $90 x$ & 1 & 35 & 39 & 809.55 & 18.40 & 38.90 & 2.18 & 2.87 \\
\hline $91 X$ & 1 & 87 & 89 & 819.57 & 18.45 & 38.10 & 2.18 & 2.76 \\
\hline $91 X$ & 2 & 58 & 60 & 820.78 & 24.24 & 47.47 & 2.03 & 2.87 \\
\hline $91 X$ & 3 & 38 & 40 & 822.08 & 18.23 & 39.20 & 2.29 & 2.94 \\
\hline
\end{tabular}

"A" does thin over the top of the rotated blocks, but not nearly as much as overlying intervals do. Unconformity " $\mathrm{A}$ " occurs about $0.09 \mathrm{~s}(90 \mathrm{~m})$ below the top of lithologic Unit V at about 620 mbsf. The age determined for this depth by interpolation between paleontological dates is $7.5 \mathrm{Ma}$.

\section{LOGGING}

Logging was attempted but the bottom-hole assembly parted from the drill string before the logging tools reached open hole (See "Operations" section).

\section{SUMMARY AND CONCLUSIONS}

Three holes were drilled at Site 717 on the distal Bengal Fan in a water depth of $4735 \mathrm{~m}$. Hole $717 \mathrm{~A}$ missed the mud line so that a second hole was spudded-in at a depth a few meters shallower. Holes 717B and 717C together drilled a continuous section from the seafloor to 828.2 mbsf. Core recovery averaged $58 \%$, being good in the finer grained mud lithologies and poor in unconsolidated silts. Only two APC cores were obtained, but a new record for XCB penetration was set at total hole depth. Loss of the bottom-hole assembly near the mud line prevented the scheduled logging run being carried out.

Site 717 was drilled on a tilted fault block into the thickest part of the sedimentary section between adjacent faults (Fig. 2). Two main units are identified on the seismic reflection records, a lower predeformational sequence (1.15 to $1.35 \mathrm{~s}$ thick) and an upper postdeformational sequence $(0.7 \mathrm{~s}$ thick). Seismic reflectors " $\mathrm{A}$ " and " $\mathrm{B}$ ", representing unconformities on the uplifted parts of fault blocks (Fig. 2), appear to be conformable at Site 717.

The stratigraphic section recovered ranges from late Quaternary to the base of late Miocene and has been divided into five main lithologic units (Fig. 4). Unit I (0-5.5 mbsf) represents the topmost muds, mud turbidites, and pelagites of (?) Holocene and latest Pleistocene age. Although the surface layer was probably washed away during penetration, a minimum sediment accumulation rate of about $25 \mathrm{~m} / \mathrm{m}$.y. can be calculated. Unit II (5.5-152 mbsf) is dominated by micaceous silt turbidites, with thin intervening muds and pelagites, deposited very rapidly during the late Pleistocene at a rate probably in excess of $350 \mathrm{~m} /$ m.y. The base of Unit II corresponds to seismic reflector "B" (Fig. 35). Units III and IV (152-533.3 mbsf) together represent a thick section of mainly mud turbidites and thin interbedded pelagic clays that accumulated at a slower average rate of nearly $70 \mathrm{~m} / \mathrm{m}$.y. through the latest Miocene to early Pleistocene. Distinctive biogenic mud turbidites were characteristic of the upper part of these units and at least two distinct pulses of silty turbidites occurred within Unit IV. The top of Unit V corresponds to seismic reflector " $Z$ " (Fig. 35). The unit (533-828.2 mbsf) comprises repeated micaceous silt and silt-mud turbidites separated by intervals (5-20 m thick) of muds and pelagic clays. The average accumulation rate for the whole of this late Miocene interval is about $90-100 \mathrm{~m} / \mathrm{m}$.y., although it is assumed that the silt turbidites were deposited much more rapidly than the intervening muds. Seismic reflector " $A$ " occurred at approximately $90 \mathrm{~m}$ below the top of the unit (Fig. 35).

The biostratigraphic control at Site 717 was based largely on nannofossils, as most of the other microfossil groups were either poorly preserved or absent in all but the uppermost unit. The site has clearly been below or very close to the carbonate compensation depth (CCD) from at least $10 \mathrm{Ma}$ to the present. Slightly better preservation of carbonate microfossils from about $0.5 \mathrm{~m}$.y. onward compared with the very barren pelagic intervals before that time indicates a general increase in the depth of the CCD to the present. Most of the biota studied have been resedimented as turbidites derived from shallower water, but the ab- 


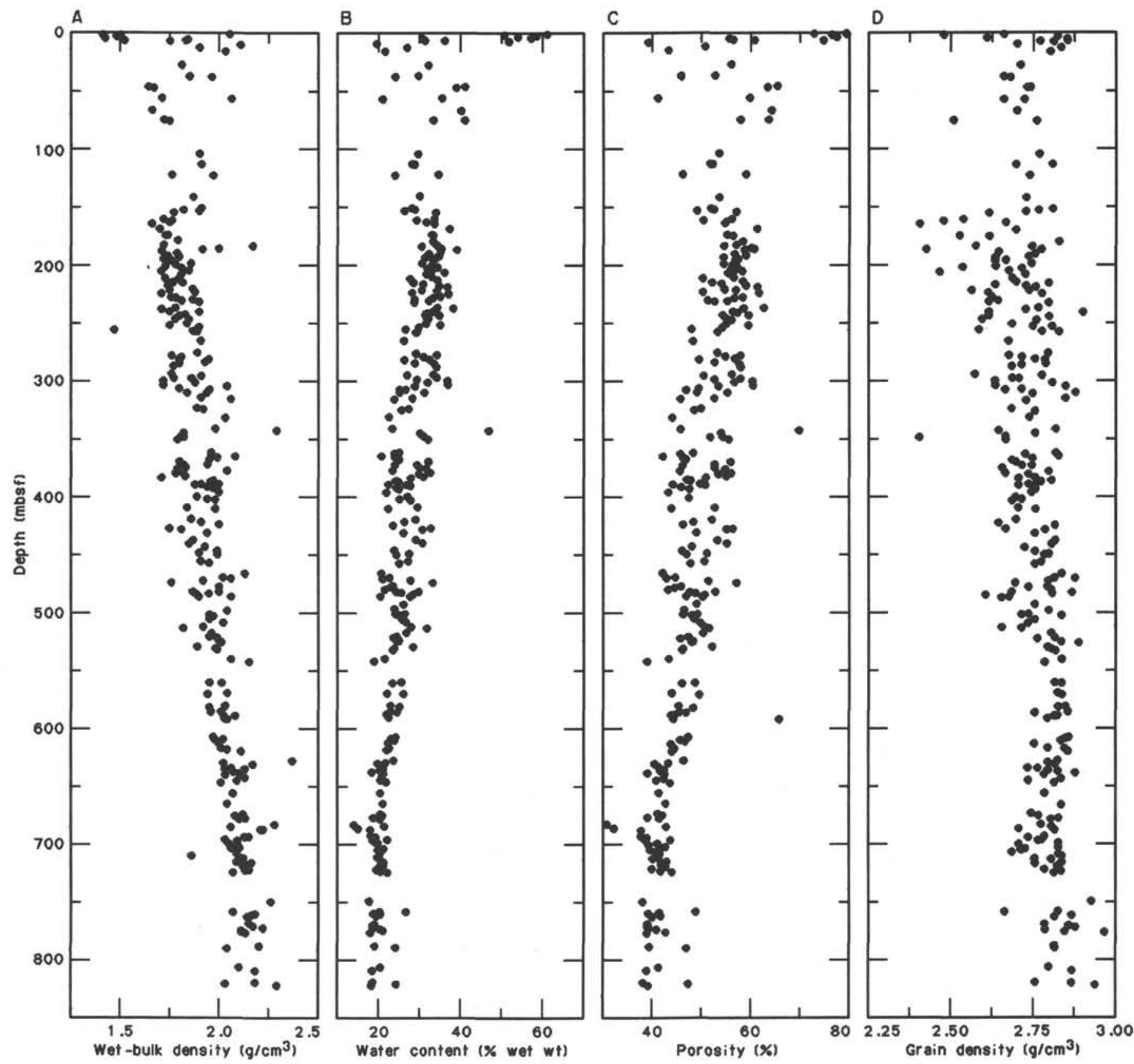

Figure 26. Index properties at Site 717. Data are from Holes 717B and 717C.

sence of mixing between nannofossil zones indicates that resedimentation took place shortly after deposition. The almost complete absence of siliceous microfossils beneath the supposed equatorial upwelling, high-productivity zone remains a problem to be resolved.

For the most part, the downhole pore-water geochemical trends were typical of those found in similar sequences on previous DSDP/ODP legs (Figs. 8 and 11 to 15 ). The data for $\mathrm{Ca}$, $\mathrm{Mg}$, alkalinity, and organic compounds together suggest that most of the section should be subject to carbonate precipitation. The downhole carbonate measurements indicate higher carbonate content within the silts than the muds so that precipitation may be taking place in the more permeable beds. Visual examination of smear slides revealed a small amount of rhombic authigenic carbonate and much silt and clay-sized carbonate of indeterminate origin. Toward the base of the hole certain hori- zons have been fully lithified with carbonate cement. The pore water from muds in the very bottom core had a completely different chemistry (high $\mathrm{Si}, \mathrm{Ca}$, and alkalinity; low $\mathrm{Mg}$ and chlorinity) with a distinct odor of polyalkylamine compounds derived from the fermentation of organic-rich sapropelic material. The most likely explanation involves the origin of the water from a zone of higher temperature water-sediment interaction, a convective circulation system, and horizontal flow of water beneath an impermeable horizon near $800 \mathrm{mbsf}$.

Total organic carbon measurements showed two features of interest at Site 717 (Fig. 10). In the upper $530 \mathrm{~m}$ (Units I to IV), the content ranged from about $0.5 \%$ to $3 \%$ and shows a marked cyclicity of between 20 and $40 \mathrm{~m}$ (i.e., half-million year cycles). In the lower silty Unit V, the content dropped to generally less than $0.5 \%$. Shipboard Rock Eval and visual description indicated that this carbon is of terrigenous origin, mostly inertinite 


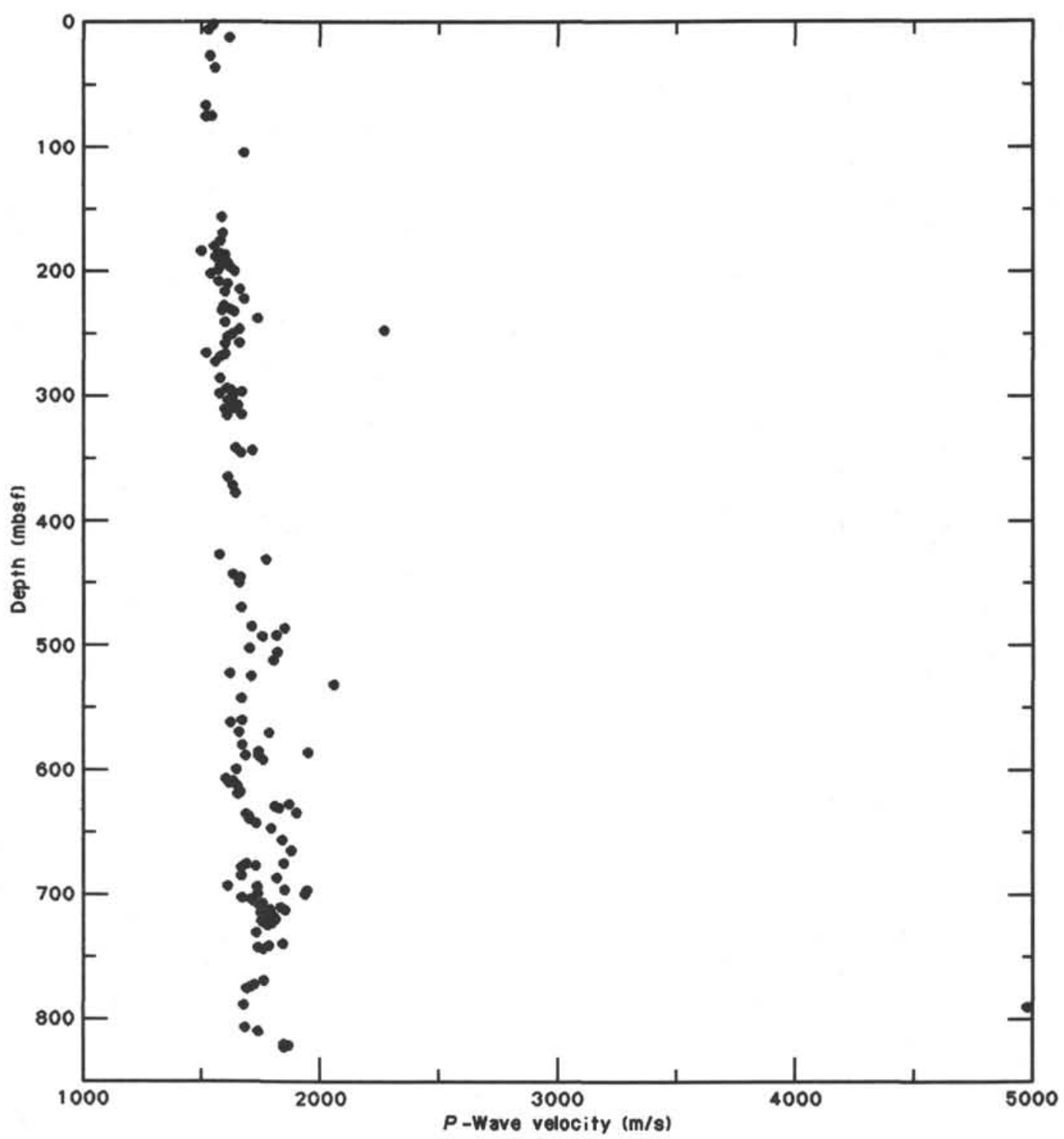

Figure 27. Sonic velocity vs. depth at Site 717.

(Type IV) and some vitrinite (Type III). The content was highest in the dark-gray muds and lowest in the silts. Methane contents were low and methane/ethane ratios very high, so that although a gas-prone source rock exists, the maturity is low.

Conventional paleomagnetic measurements were made on board, but due to the equatorial location, nonorientated $\mathrm{XCB}$ cores, and extensive core disturbance in the older sections recovered, reliable magnetostratigraphy was not possible. However, the magnetic susceptibility properties of different lithofacies types proved extremely interesting. In part, high susceptibility correlates closely with the dark-gray mud turbidites and in part, it follows a larger scale periodicity (Fig. 22). These results and the nature and distribution of the magnetic or paramagnetic material involved are under further investigation.

Sediment physical properties show consistent downhole variation (Figs. 26A to $26 \mathrm{C}$ ), although many of the data from deeper within the section have been adversely influenced by drilling disturbance. The sense and downhole increase in the anisotropy of sonic velocity, which showed that the horizontal velocity through the sediments is greater than the vertical, is particularly significant. This provided clear evidence that the sediments are experiencing a lateral stress in excess of the vertical stress due to over- burden pressure. The thermal conductivity measurements convert downhole temperatures obtained from the heat probe into heat flow. The resulting heat flow calculated through the top $150 \mathrm{~m}$ of section at Site 717 is about normal for the age of the ocean crust.

In summary, the principal results of drilling at Site 717 are as follows.

1. A successful reference section was obtained through seismic reflectors " $A$ " and "B" to the base of the late Miocene. There is evidence of lateral stress, but heat flow is normal and no marked unconformities are apparent.

2. A very good record of extremely distal fan sedimentation was recovered showing the nature, thickness, and vertical sequence of turbidites that have been transported over $2500 \mathrm{~km}$. Correlations can be made with a similar sequence of fan sediments recovered at Site 218 some $1000 \mathrm{~km}$ further north.

3. At least three different sources of turbidites can be tentatively identified: silts and muds from the Ganges-Brahmaputra delta front, dark-gray organic-rich muds from the upper slope in the northern or western Bay of Bengal, and greenish biogenic turbidites from a more local seamount or outer shelf source. 
Table 11. Sonic velocity from Site 717 .

\begin{tabular}{|c|c|c|c|c|}
\hline Hole & $\begin{array}{l}\text { Core- } \\
\text { Sect. }\end{array}$ & $\begin{array}{l}\text { Interval } \\
(\mathrm{cm})\end{array}$ & $\begin{array}{l}\text { Depth } \\
\text { (mbsf) }\end{array}$ & $\begin{array}{c}\text { Sonic } \\
\text { velocity } \\
(\mathrm{km} / \mathrm{s})\end{array}$ \\
\hline B & $01 \mathrm{H}-2$ & $060-065$ & 002.13 & 1.550 \\
\hline B & $02 \mathrm{H}-2$ & 090-094 & 006.42 & 1.530 \\
\hline B & $02 \mathrm{H}-6$ & $113-115$ & 012.61 & 1.620 \\
\hline C & $04 X-1$ & $028-030$ & 027.29 & 1.540 \\
\hline C & $05 X-1$ & $038-040$ & 036.81 & 1.560 \\
\hline C & $08 X-2$ & 064-069 & 067.15 & 1.520 \\
\hline C & $10 \mathrm{X}-1$ & $076-081$ & 075.29 & 1.545 \\
\hline C & $10 X-1$ & $113-118$ & 075.65 & 1.520 \\
\hline C & $14 X-2$ & $019-022$ & 104.70 & 1.680 \\
\hline C & $20 X-4$ & $021-024$ & 156.72 & 1.586 \\
\hline C & $22 \mathrm{X}-1$ & $019-022$ & 169.70 & 1.590 \\
\hline C & $22 X-5$ & $015-020$ & 175.70 & 1.580 \\
\hline C & $23 \mathrm{X}-1$ & $113-118$ & 180.15 & 1.555 \\
\hline C & $23 X-4$ & $060-065$ & 184.13 & 1.500 \\
\hline C & $23 X-5$ & $113-118$ & 186.15 & 1.580 \\
\hline C & $23 \mathrm{X}-6$ & $060-065$ & 187.13 & 1.600 \\
\hline C & $24 X-1$ & $020-024$ & 188.71 & 1.560 \\
\hline C & $24 X-3$ & $113-117$ & 192.65 & 1.580 \\
\hline C & $24 X-4$ & $060-065$ & 193.63 & 1.610 \\
\hline C & $24 X-5$ & $120-125$ & 195.80 & 1.580 \\
\hline C & $24 X-6$ & $060-065$ & 196.63 & 1.620 \\
\hline C & $25 X-1$ & $114-118$ & 199.15 & 1.570 \\
\hline C & $25 X-2$ & $060-064$ & 200.12 & 1.640 \\
\hline C & $25 X-3$ & $113-117$ & 202.15 & 1.540 \\
\hline C & $26 \mathrm{X}-1$ & $070-073$ & 208.21 & 1.573 \\
\hline C & $26 X-2$ & $124-127$ & 210.25 & 1.610 \\
\hline C & $26 X-5$ & $113-118$ & 214.65 & 1.662 \\
\hline C & $26 X-7$ & $010-014$ & 216.62 & 1.599 \\
\hline C & $27 X-4$ & $060-063$ & 222.62 & 1.680 \\
\hline C & $28 \mathrm{X}-1$ & $128-132$ & 227.79 & 1.595 \\
\hline C & $28 \mathrm{X}-3$ & $147-150$ & 230.98 & 1.623 \\
\hline C & $28 X-4$ & $063-067$ & 231.65 & 1.586 \\
\hline C & $28 X-5$ & 011-015 & 232.63 & 1.637 \\
\hline C & $29 \times-2$ & $063-066$ & 238.15 & 1.737 \\
\hline C & $29 X-4$ & $062-065$ & 241.14 & 1.599 \\
\hline C & $30 X-1$ & $118-123$ & 246.69 & 1.660 \\
\hline C & $30 \times-2$ & $060-064$ & 247.62 & 2.270 \\
\hline C & $30 X-4$ & $061-064$ & 250.62 & 1.630 \\
\hline C & $30 X-5$ & $112-126$ & 252.64 & 1.610 \\
\hline C & $31 X-2$ & $113-117$ & 257.65 & 1.660 \\
\hline C & $31 X-3$ & $020-024$ & 258.22 & 1.600 \\
\hline C & $32 X-1$ & $117-121$ & 265.69 & 1.520 \\
\hline C & $33 X-2$ & $064-068$ & 266.65 & 1.600 \\
\hline C & $33 X-3$ & $113-117$ & 268.64 & 1.580 \\
\hline C & $33 X-6$ & $060-064$ & 272.62 & 1.560 \\
\hline C & $34 X-2$ & 090-094 & 285.92 & 1.580 \\
\hline C & $35 X-1$ & $113-117$ & 294.00 & 1.608 \\
\hline C & $35 X-2$ & 090-094 & 295.42 & 1.626 \\
\hline C & $35 X-4$ & $060-064$ & 298.12 & 1.578 \\
\hline C & $35 X-3$ & $060-064$ & 296.62 & 1.670 \\
\hline $\mathrm{C}$ & $35 X-6$ & $060-064$ & 301.12 & 1.633 \\
\hline C & $36 X-1$ & $116-119$ & 303.67 & 1.612 \\
\hline C & $36 X-2$ & 063-068 & 304.65 & 1.622 \\
\hline C & $36 X-3$ & $120-124$ & 306.72 & 1.628 \\
\hline $\mathrm{C}$ & $36 X-4$ & $060-064$ & 307.62 & 1.655 \\
\hline C & $36 X-5$ & $124-128$ & 309.76 & 1.636 \\
\hline C & $36 \times-6$ & $061-065$ & 310.63 & 1.600 \\
\hline C & $37 X-2$ & $136-139$ & 314.86 & 1.670 \\
\hline C & $37 X-3$ & $072-073$ & 315.74 & 1.609 \\
\hline C & $40 X-1$ & $110-114$ & 341.62 & 1.645 \\
\hline C & $40 X-3$ & $104-107$ & 343.55 & 1.716 \\
\hline C & $40 X-4$ & $032-036$ & 345.34 & 1.667 \\
\hline $\mathrm{C}$ & $42 X-4$ & $087-090$ & 364.88 & 1.612 \\
\hline $\mathrm{C}$ & $43 X-2$ & $110-113$ & 371.62 & 1.632 \\
\hline C & $43 X-6$ & $110-113$ & 377.62 & 1.644 \\
\hline C & $49 X-1$ & $146-150$ & 427.48 & 1.577 \\
\hline C & $49 X-4$ & 063-064 & 431.13 & 1.773 \\
\hline C & $50 X-6$ & $026-028$ & 443.27 & 1.634 \\
\hline $\mathrm{C}$ & $52 X-1$ & $104-107$ & 445.55 & 1.665 \\
\hline C & $51 X-4$ & $041-043$ & 449.92 & 1.660 \\
\hline C & $53 \times-4$ & $138-140$ & 469.90 & 1.668 \\
\hline C & $55 X-2$ & $073-075$ & 485.24 & 1.712 \\
\hline $\mathrm{C}$ & $55 \mathrm{X}-3$ & $047-050$ & 486.48 & 1.851 \\
\hline C & $55 X-C$ & $035-037$ & 492.30 & 1.817 \\
\hline C & $56 \mathrm{X}-1$ & $068-070$ & 493.18 & 1.757 \\
\hline C & $57 X-1$ & $075-077$ & 502.76 & 1.703 \\
\hline C & $57 X-3$ & $065-068$ & 505.65 & 1.821 \\
\hline C & $58 \mathrm{X}-1$ & $067-069$ & 512.18 & 1.804 \\
\hline
\end{tabular}

Table 11 (continued).

\begin{tabular}{|c|c|c|c|c|}
\hline Hole & $\begin{array}{l}\text { Core- } \\
\text { Sect. }\end{array}$ & $\begin{array}{c}\text { Interval } \\
(\mathrm{cm})\end{array}$ & $\begin{array}{l}\text { Depth } \\
\text { (mbsf) }\end{array}$ & $\begin{array}{c}\text { Sonic } \\
\text { velocity } \\
(\mathrm{km} / \mathrm{s})\end{array}$ \\
\hline C & $59 X-2$ & $022-026$ & 522.74 & 1.619 \\
\hline C & $59 \mathrm{X}-3$ & $092-097$ & 524.94 & 1.710 \\
\hline C & $60 X-1$ & $114-118$ & 531.66 & 2.060 \\
\hline C & $61 X-2$ & $128-132$ & 542.80 & 1.670 \\
\hline C & $63 X-1$ & $134-136$ & 560.35 & 1.672 \\
\hline C & $63 X-2$ & $050-053$ & 562.01 & 1.624 \\
\hline C & $64 X-1$ & $141-145$ & 569.95 & 1.660 \\
\hline C & $64 X-2$ & $038-042$ & 570.40 & 1.787 \\
\hline C & $65 X-2$ & $076-078$ & 580.27 & 1.673 \\
\hline C & $65 X-6$ & $021-023$ & 585.72 & 1.743 \\
\hline C & $65 \mathrm{X}-\mathrm{C}$ & $017-020$ & 586.30 & 1.951 \\
\hline C & $66 X-1$ & $115-117$ & 588.66 & 1.687 \\
\hline C & $66 X-2$ & 014-016 & 589.15 & 1.742 \\
\hline C & $66 X-4$ & $021-025$ & 592.23 & 1.761 \\
\hline C & $67 X-2$ & $120-122$ & 599.71 & 1.648 \\
\hline C & $68 \mathrm{X}-1$ & 088-091 & 607.40 & 1.604 \\
\hline C & $68 X-2$ & $106-108$ & 609.07 & 1.635 \\
\hline C & $68 X-3$ & 096-098 & 610.47 & 1.616 \\
\hline C & $68 X-5$ & $070-072$ & 613.21 & 1.653 \\
\hline C & $69 X-1$ & $115-117$ & 617.16 & 1.661 \\
\hline C & $69 X-2$ & $033-036$ & 617.85 & 1.666 \\
\hline C & $69 X-3$ & $063-066$ & 619.65 & 1.654 \\
\hline C & $70 X-2$ & $065-067$ & 627.66 & 1.872 \\
\hline C & $70 X-3$ & $085-087$ & 629.36 & 1.811 \\
\hline C & $70 \times-4$ & $058-060$ & 630.59 & 1.829 \\
\hline C & $70 \mathrm{X}-\mathrm{C}$ & 006-008 & 634.57 & 1.903 \\
\hline C & $71 X-1$ & $050-053$ & 635.51 & 1.689 \\
\hline C & $71 X-2$ & 049-051 & 637.00 & 1.699 \\
\hline C & $71 X-3$ & $042-046$ & 638.44 & 1.703 \\
\hline C & $71 X-4$ & $015-017$ & 639.66 & 1.704 \\
\hline C & $71 X-C$ & $014-016$ & 642.85 & 1.732 \\
\hline C & $72 X-2$ & 083-086 & 646.85 & 1.796 \\
\hline C & $73 X-2$ & $061-062$ & 656.12 & 1.843 \\
\hline C & $74 X-1$ & $112-115$ & 664.63 & 1.881 \\
\hline C & $75 X-1$ & $103-108$ & 675.05 & 1.850 \\
\hline C & $75 X-2$ & $078-083$ & 675.30 & 1.690 \\
\hline C & $75 X-3$ & $105-110$ & 677.07 & 1.730 \\
\hline C & $75 X-4$ & 065-070 & 678.17 & 1.670 \\
\hline C & $76 X-2$ & 090-097 & 684.94 & 1.670 \\
\hline C & $76 \times-3$ & $121-126$ & 686.73 & 1.820 \\
\hline C & $77 X-1$ & $126-129$ & 693.26 & 1.612 \\
\hline C & $77 X-2$ & $036-040$ & 693.88 & 1.737 \\
\hline C & $77 X-3$ & $123-126$ & 696.25 & 1.853 \\
\hline C & $77 \times-4$ & $023-027$ & 696.75 & 1.948 \\
\hline C & $77 X-5$ & $118-125$ & 699.21 & 1.740 \\
\hline C & $77 X-6$ & $040-044$ & 699.92 & 1.939 \\
\hline C & $78 X-1$ & $121-123$ & 702.72 & 1.672 \\
\hline C & $78 X-2$ & $074-077$ & 703.75 & 1.710 \\
\hline C & $78 \times-3$ & $058-061$ & 705.10 & 1.720 \\
\hline C & $78 \times-4$ & $109-112$ & 707.11 & 1.760 \\
\hline $\mathrm{C}$ & $78 X-5$ & $114-117$ & 708.65 & 1.744 \\
\hline C & $78 X-6$ & $143-146$ & 710.45 & 1.837 \\
\hline $\mathrm{C}$ & $79 X-1$ & $116-118$ & 712.17 & 1.793 \\
\hline $\mathrm{C}$ & $79 \mathrm{X}-2$ & 007-009 & 712.58 & 1.855 \\
\hline$C$ & $79 X-3$ & $110-114$ & 715.12 & 1.753 \\
\hline C & $79 X-4$ & $062-064$ & 716.13 & 1.790 \\
\hline C & $79 X-5$ & $134-136$ & 718.35 & 1.809 \\
\hline C & $79 X-6$ & $024-026$ & 719.85 & 1.815 \\
\hline C & $80 X-1$ & $109-111$ & 721.60 & 1.755 \\
\hline C & $80 X-2$ & $110-112$ & 723.11 & 1.799 \\
\hline C & $80 X-3$ & $105-108$ & 724.57 & 1.780 \\
\hline C & $83 X-1$ & $065-069$ & 730.67 & 1.733 \\
\hline C & $84 X-1$ & $002-004$ & 739.53 & 1.845 \\
\hline C & $84 X-2$ & $026-028$ & 741.27 & 1.786 \\
\hline C & $84 X-3$ & $023-025$ & 742.74 & 1.740 \\
\hline C & $84 X-C$ & $011-013$ & 743.90 & 1.761 \\
\hline C & $85 \mathrm{X}-1$ & $080-083$ & 768.81 & 1.765 \\
\hline C & $85 X-3$ & $117-120$ & 772.18 & 1.723 \\
\hline C & $85 X-4$ & $098-101$ & 773.49 & 1.710 \\
\hline C & $85 X-5$ & $123-125$ & 775.24 & 1.690 \\
\hline C & $87 X-1$ & $134-138$ & 788.35 & 1.680 \\
\hline C & $87 X-C$ & $031-035$ & 790.29 & 4.978 \\
\hline C & $89 X-1$ & $041-045$ & 806.43 & 1.685 \\
\hline $\mathrm{C}$ & $90 \mathrm{X}-1$ & 035-039 & 809.55 & 1.740 \\
\hline C & $91 X-1$ & $087-089$ & 819.57 & 1.849 \\
\hline C & $91 X-2$ & $058-060$ & 820.78 & 1.869 \\
\hline C & $91 X-3$ & $038-040$ & 822.08 & 1.850 \\
\hline
\end{tabular}




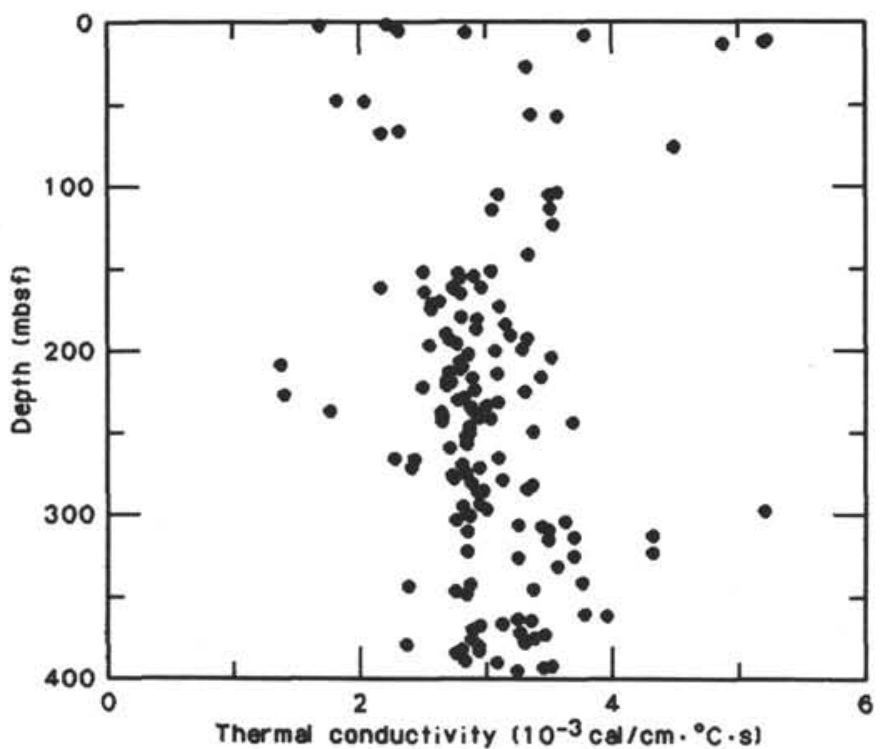

Figure 28. Thermal conductivity vs. depth at Site 717 .

4. One of the main controls on sedimentation appears to have been sea-level variation (low stands for the silt turbidites, high stands for the mud turbidites). A second important control was probably changes in rates of erosion related to particular phases of Himalayan uplift. Local tectonic effects, perhaps related to intraplate deformation, may have resulted in the more local supply of biogenic turbidites from seismically triggered slumps on adjacent seamounts.

\section{REFERENCES}

Berggren, W. A., Kent, D. V., and van Couvering, J. A., 1985. The Neogene: Part 2, Neogene geochronology and chronostratigraphy. In Snelling, N. J. (Ed.), The Chronology of the Geological Record. Geol. Soc. (London) Mem. 10:211-260.

Blanc, G., Boulegue, J., Badaut, D. and Stouff, P., 1986. Premiers résultats de la campagne oceanographique Hydrotherm du Marion Dufresne sur la fosse Atlantis II. C. R. Acad. Sci. Paris, 302:175180.

Bukry, D., 1985. Tropical Pacific silicoflagellate zonation and paleotemperature trends of the Cenozoic. In Mayer, L., Theyer, F., et al., Init. Repts. DSDP, 85: Washington (U.S. Govt. Printing Office), 477-497.

Claypool, G. E., and Kaplan, I. R., 1974. The origin and distribution of methane in marine sediments, In Kaplan, I. R. (Ed.), Natural Gases in Marine Sediments: New York (Plenum), 94-129.

Curray, J. R. and Moore, D. G., 1971. Growth of the Bengal deep-sea fan and denudation of the Himalayas. Geol. Soc. Am. Bull., 82: 563-572.

Curray, J. R., Emmel, F. J., Moore, D. G. and Raitt, R. W., 1982. Structure, tectonics and geological history of the northeastern Indian Ocean. In Nairn, A.E.M., and Stehli, F. G. (Eds.), The Ocean Basins and Margins (Vol. 6). The Indian Ocean: New York (Plenum Press), 399-450.

Degens, E. T., and Mopper, K., 1976. Factors controlling the distribution and early diagenesis of organic material in marine sediments. In
Rilley, J. P., and Chester, R. (Eds.), Chemical Oceanography: New York (Academic Press), 6:60-114.

Geller, C. A., Weissel, J. K., and Anderson, R. N., 1983. Heat transfer and intraplate deformation in the central Indian Ocean. J. Geophys. Res., 88:1018-1032.

Gieskes, J., and Petersman, G., 1986. Water chemistry procedures aboard JOIDES Resolution-Some comments. ODP Technical note, 5:46.

Kvenvolden, K. A., and McDonald, T. J., 1986. Organic geochemistry aboard JOIDES Resolution, an assay. ODP Technical Note 6:5-6.

Ling, H. Y., 1975. Radiolaria: Leg 31 of the Deep Sea Drilling Project. In Karig, D. E., Ingle, J. C., et al., Init. Repts. DSDP, 31: Washington (U.S. Govt. Printing Office), 703-761.

Locker, S., and Martini, E., 1986. Silicoflagellates and some sponge spicules from the southwest Pacific, Deep Sea Drilling Project, Leg 90. In Kennett, J. P., von der Borch, C. C., et al., Init. Repts. DSDP, 90, Pt. 2: Washington (U.S. Govt. Printing Office), 887-924.

Moore, D. G., Curray, J. R., Raitt, R. W., and Emmel, F. J., 1974 Stratigraphic-seismic section correlation and implications to Bengal fan history. In Von der Borch, C. C., Sclater, J. G., et al., Init. Repts. DSDP, 22: Washington (U.S. Govt. Printing Office), 403412.

Okada, H., and Bukry, D., 1980. Supplementary modification and introduction of code numbers to the low latitude coccolith biostratigraphic zonation (Bukry, 1973; 1975). Mar. Micropaleont., 5:321325.

Parsons, B., and Sclater, J. G., 1977. An analysis of the variation of ocean floor bathymetry and heat flow with age. J. Geophys. Res., 82:803-827.

Perch-Nielsen, K., 1985. Silicoflagellates. In Bolli, H. M., Saunders, J. B., and Perch-Nielsen, K. P., Plankton Stratigraphy: Cambridge, U.K. (Cambridge University Press), 811-846.

Powell, C.M.A., and Conaghan, P. J., 1973. Plate tectonics and the Himalayas. Earth Planet. Sci. Lett., 20:1-12.

Richards, A. F., 1962. Investigations of deep sea sediment cores II: Mass physical properties. U.S. Navy Hydrographic Office, Tech. Rep. 106:146.

Sayles, F. L., and Manheim, F. T., 1975. Interstitial solutions and diagenesis in deeply buried marine sediments: results from the Deep Sea Drilling Project. Geochim. Cosmochim. Acta, 39:103-127.

Sclater, J. G., and Fisher, R. L., 1974. The evolution of the east central Indian Ocean with emphasis on the tectonic setting of the Ninety East Ridge, Geol. Soc. Am. Bull., 85:683-702.

Sclater, J. G., Luyendyk, B. P., and Meinke, L., 1976. Magnetic lineations in the southern part of the Central Indian Basin. Geol. Soc. Am. Bull., 87:371-378.

Skempton, A. W., 1970. The consolidation of clay by gravitational compaction. Q. J. Geol. Soc. London, 125:373-411.

Stein, S., and Okal, E. A., 1978. Seismicity and tectonics of the Ninety East Ridge area: Evidence for internal deformation of the Indian plate. J. Geophys. Res., 83:2233-2245.

Thompson, R. W., 1974. Mineralogy of sands from the Bengal and Nicobar Fans, sites 218 and 211, eastern Indian Ocean. In von der Borch, C. C., Sclater, J. G., et al., 1974. Init. Repts. DSDP, 22: Washington (U. S. Govt. Printing Office), 711-714.

Tissot, B. P., and Welte, D. H., 1984. Petroleum Formation and Occurrence (2nd Ed.): Berlin (Springer-Verlag), 699.

Weissel, J. K., Anderson, R. N., and Geller, C. A., 1980. Deformation of the Indo-Australian plate. Nature, 287:284-291.

\section{Ms 116A-105}


Table 12. Thermal conductivity measurements from Site 717.

\begin{tabular}{|c|c|c|c|}
\hline Core-Sect. & $\begin{array}{c}\text { Interval } \\
(\mathrm{cm})\end{array}$ & $\begin{array}{l}\text { Depth } \\
\text { (mbsf) }\end{array}$ & $\begin{array}{l}\text { Conductivit } \\
10^{-3} \mathrm{cal} / \\
\left({ }^{\circ} \mathrm{C} \cdot \mathrm{cm} \cdot\right.\end{array}$ \\
\hline \multicolumn{4}{|l|}{ Hole 717B } \\
\hline $01 \mathrm{H}-1$ & 115 & 001.15 & 02.2310 \\
\hline $01 \mathrm{H}-2$ & 063 & 002.13 & 01.6957 \\
\hline $01 \mathrm{H}-3$ & 063 & 003.63 & 02.3159 \\
\hline $02 \mathrm{H}-1$ & 115 & 005.15 & 02.3282 \\
\hline $02 \mathrm{H}-2$ & 063 & 006.13 & 02.8586 \\
\hline $02 \mathrm{H}-3$ & 115 & 008.15 & 03.8068 \\
\hline $02 \mathrm{H}-5$ & 115 & 011.15 & 05.2592 \\
\hline $02 \mathrm{H}-6$ & 063 & 012.13 & 05.2333 \\
\hline $02 \mathrm{H}-7$ & 030 & 013.30 & 04.9084 \\
\hline \multicolumn{4}{|l|}{ Hole $717 \mathrm{C}$} \\
\hline $04 X-1$ & 025 & 027.25 & 03.339 \\
\hline $06 \mathrm{X}-1$ & 147 & 047.47 & 01.831 \\
\hline $06 \times-2$ & 052 & 048.02 & 02.053 \\
\hline $07 X-1$ & 063 & 056.03 & 03.374 \\
\hline $07 X-2$ & 003 & 057.30 & 03.587 \\
\hline $08 X-1$ & 115 & 066.13 & 02.329 \\
\hline $08 \times-2$ & 085 & 067.35 & 02.186 \\
\hline $10 X-1$ & 140 & 075.93 & 04.517 \\
\hline $14 X-1$ & 070 & 103.70 & 03.588 \\
\hline $14 X-2$ & 040 & 104.90 & 03.115 \\
\hline $14 X-2$ & 079 & 105.29 & 03.520 \\
\hline $15 \mathrm{X}-1$ & 120 & 113.70 & 03.526 \\
\hline $15 X-2$ & 025 & 114.25 & 03.065 \\
\hline $16 \mathrm{X}-1$ & 115 & 123.15 & 03.551 \\
\hline $19 X-1$ & 063 & 141.63 & 03.353 \\
\hline $20 X-1$ & 115 & 151.65 & 03.058 \\
\hline $20 X-2$ & 003 & 152.03 & 02.518 \\
\hline $20 X-2$ & 063 & 152.63 & 02.797 \\
\hline $20 X-3$ & 110 & 154.60 & 02.921 \\
\hline $20 X-4$ & 054 & 155.54 & 02.812 \\
\hline $21 X-1$ & 115 & 161.15 & 02.758 \\
\hline $21 \times-2$ & 003 & 161.53 & 02.181 \\
\hline $21 X-2$ & 005 & 161.55 & 02.981 \\
\hline $21 X-2$ & 063 & 162.13 & 02.758 \\
\hline $21 X-3$ & 115 & 164.15 & 02.528 \\
\hline $21 X-4$ & 063 & 165.13 & 02.816 \\
\hline $22 X-1$ & 038 & 169.88 & 02.647 \\
\hline $22 X-2$ & 038 & 171.38 & 02.587 \\
\hline $22 X-3$ & 052 & 173.02 & 03.125 \\
\hline $22 \times-4$ & 046 & 174.46 & 02.582 \\
\hline $23 X-1$ & 046 & 179.46 & 02.822 \\
\hline $23 X-2$ & 033 & 180.83 & 02.949 \\
\hline $23 \times-4$ & 040 & 183.90 & 03.175 \\
\hline $23 X-6$ & 040 & 186.90 & 02.941 \\
\hline $24 X-1$ & 115 & 189.65 & 02.702 \\
\hline $24 X-2$ & 062 & 190.62 & 03.215 \\
\hline $24 X-3$ & 115 & 192.65 & 03.351 \\
\hline $24 X-4$ & 062 & 193.62 & 02.733 \\
\hline $24 X-5$ & 115 & 195.65 & 02.785 \\
\hline $24 X-6$ & 062 & 196.62 & 02.567 \\
\hline
\end{tabular}

Table 12 (continued).

\begin{tabular}{|c|c|c|c|}
\hline Core-Sect. & $\begin{array}{c}\text { Interval } \\
(\mathrm{cm})\end{array}$ & $\begin{array}{l}\text { Depth } \\
\text { (mbsf) }\end{array}$ & $\begin{array}{c}\text { Conductivity } \\
10^{-3} \mathrm{cal} / \\
\left({ }^{\circ} \mathrm{C} \cdot \mathrm{cm} \cdot \mathrm{s}\right)\end{array}$ \\
\hline $25 \mathrm{X}-1$ & 115 & 199.15 & 03.305 \\
\hline $25 X-2$ & 062 & 200.12 & 03.089 \\
\hline $25 X-3$ & 115 & 202.15 & 02.875 \\
\hline $25 X-4$ & 062 & 204.12 & 03.538 \\
\hline $25 X-5$ & 115 & 206.65 & 02.808 \\
\hline $26 \mathrm{X}-1$ & 115 & 208.65 & 01.381 \\
\hline $26 \mathrm{X}-2$ & 062 & 209.62 & 02.830 \\
\hline $26 X-3$ & 062 & 211.12 & 02.806 \\
\hline $26 X-4$ & 113 & 213.13 & 02.719 \\
\hline $26 X-5$ & 063 & 214.13 & 03.106 \\
\hline $26 X-5$ & 115 & 216.13 & 03.453 \\
\hline $26 X-7$ & 028 & 216.88 & 02.908 \\
\hline $27 X-1$ & 115 & 218.15 & 02.709 \\
\hline $27 X-2$ & 063 & 219.13 & 02.738 \\
\hline $27 X-3$ & 115 & 221.15 & 02.703 \\
\hline $27 X-4$ & 063 & 222.13 & 02.513 \\
\hline $27 X-5$ & 115 & 224.15 & 02.929 \\
\hline $27 X-6$ & 063 & 225.15 & 03.327 \\
\hline $28 \mathrm{X}-1$ & 115 & 227.15 & 01.410 \\
\hline $28 X-2$ & 063 & 228.63 & 02.843 \\
\hline $28 \mathrm{X}-3$ & 115 & 230.15 & 02.791 \\
\hline $28 X-4$ & 063 & 231.63 & 03.115 \\
\hline $28 X-5$ & 115 & 233.65 & 03.025 \\
\hline $28 X-6$ & 040 & 234.40 & 02.896 \\
\hline $29 \mathrm{X}-1$ & 113 & 237.13 & 01.776 \\
\hline $29 \mathrm{X}-1$ & 149 & 237.49 & 02.659 \\
\hline $29 \mathrm{X}-2$ & 060 & 238.10 & 02.930 \\
\hline $29 X-3$ & 113 & 240.13 & 02.672 \\
\hline $29 X-4$ & 060 & 241.10 & 02.966 \\
\hline $29 \mathrm{X}-4$ & 113 & 241.63 & 03.054 \\
\hline $29 X-5$ & 115 & 243.15 & 02.668 \\
\hline $29 X-6$ & 063 & 244.13 & 03.708 \\
\hline $30 \mathrm{X}-1$ & 115 & 246.65 & 02.889 \\
\hline $30 \mathrm{X}-2$ & 063 & 247.63 & 02.889 \\
\hline $30 X-3$ & 115 & 249.65 & 03.393 \\
\hline $30 \times-4$ & 063 & 250.63 & 02.889 \\
\hline $30 X-5$ & 115 & 252.65 & 02.861 \\
\hline $30 \mathrm{X}-6$ & 063 & 253.63 & 02.866 \\
\hline $31 X-2$ & 061 & 257.11 & 02.865 \\
\hline $31 X-2$ & 148 & 259.48 & 02.731 \\
\hline $32 X-1$ & 113 & 265.63 & 03.118 \\
\hline $32 X-1$ & 148 & 265.98 & 02.292 \\
\hline $32 X-2$ & 061 & 266.61 & 02.451 \\
\hline $32 X-3$ & 115 & 271.65 & 02.427 \\
\hline $32 X-4$ & 062 & 269.62 & 02.830 \\
\hline $32 X-5$ & 115 & 271.65 & 02.968 \\
\hline $33 \mathrm{X}-1$ & 115 & 275.15 & 02.860 \\
\hline $33 X-2$ & 062 & 276.12 & 02.753 \\
\hline $33 \mathrm{X}-3$ & 115 & 278.15 & 02.763 \\
\hline $33 \times-4$ & 062 & 279.12 & 03.152 \\
\hline $33 X-5$ & 115 & 281.15 & 02.904 \\
\hline $33 X-6$ & 062 & 282.12 & 03.388 \\
\hline $34 X-1$ & 115 & 284.65 & 03.344 \\
\hline $34 X-2$ & 062 & 285.62 & 02.999 \\
\hline
\end{tabular}


Table 12 (continued).

\begin{tabular}{|c|c|c|c|}
\hline Core-Sect. & $\begin{array}{l}\text { Interval } \\
(\mathrm{cm})\end{array}$ & $\begin{array}{l}\text { Depth } \\
\text { (mbsf) }\end{array}$ & $\begin{array}{c}\text { Conductivity } \\
10^{-3} \mathrm{cal} / \\
\left({ }^{\circ} \mathrm{C} \cdot \mathrm{cm} \cdot \mathrm{s}\right)\end{array}$ \\
\hline $34 X-3$ & 115 & 287.12 & 02.955 \\
\hline $35 X-1$ & 115 & 294.15 & 02.969 \\
\hline $35 X-2$ & 062 & 295.12 & 02.832 \\
\hline $35 X-3$ & 115 & 297.15 & 03.021 \\
\hline $35 X-4$ & 062 & 298.12 & 05.236 \\
\hline $35 X-5$ & 115 & 300.15 & 02.866 \\
\hline $35 X-6$ & 062 & 301.12 & 02.888 \\
\hline $36 \mathrm{X}-1$ & 115 & 303.65 & 02.777 \\
\hline $36 X-2$ & 062 & 304.62 & 03.648 \\
\hline $36 X-3$ & 115 & 306.65 & 03.273 \\
\hline $36 X-4$ & 062 & 307.62 & 03.462 \\
\hline $36 X-5$ & 115 & 309.65 & 03.514 \\
\hline $36 \times-6$ & 062 & 310.62 & 02.868 \\
\hline $37 X-1$ & 115 & 313.15 & 04.344 \\
\hline $37 X-2$ & 062 & 314.12 & 03.717 \\
\hline $37 X-3$ & 062 & 315.62 & 03.513 \\
\hline $38 X-1$ & 115 & 322.65 & 02.868 \\
\hline $38 X-2$ & 062 & 323.62 & 04.344 \\
\hline $38 X-3$ & 115 & 325.65 & 03.717 \\
\hline $38 \times-4$ & 062 & 326.62 & 03.273 \\
\hline $39 X-1$ & 095 & 331.95 & 03.587 \\
\hline $40 X-1$ & 115 & 341.65 & 03.784 \\
\hline $40 X-2$ & 062 & 342.62 & 02.894 \\
\hline $40 X-3$ & 115 & 343.65 & 02.401 \\
\hline $40 \times-4$ & 062 & 345.62 & 03.394 \\
\hline $40 X-5$ & 115 & 346.65 & 02.775 \\
\hline $40 X-6$ & 062 & 348.62 & 02.863 \\
\hline $42 X-1$ & 115 & 360.65 & 03.804 \\
\hline $42 X-2$ & 062 & 361.62 & 03.982 \\
\hline $42 X-3$ & 115 & 363.65 & 03.271 \\
\hline $42 X-4$ & 062 & 364.62 & 03.378 \\
\hline $42 X-5$ & 115 & 366.65 & 03.149 \\
\hline $42 X-6$ & 063 & 367.62 & 02.972 \\
\hline $43 X-1$ & 115 & 370.15 & 02.915 \\
\hline $43 X-2$ & 062 & 372.12 & 03.291 \\
\hline $43 X-3$ & 115 & 373.15 & 03.488 \\
\hline $43 \times-4$ & 062 & 375.12 & 03.405 \\
\hline $43 X-5$ & 115 & 376.15 & 02.906 \\
\hline $43 X-6$ & 062 & 378.12 & 03.322 \\
\hline $44 X-1$ & 068 & 379.18 & 02.383 \\
\hline $44 X-2$ & 068 & 380.18 & 02.959 \\
\hline $44 X-3$ & 068 & 382.18 & 02.823 \\
\hline $44 X-4$ & 075 & 383.25 & 02.959 \\
\hline $44 X-4$ & 148 & 384.48 & 02.774 \\
\hline $45 X-1$ & 113 & 389.13 & 02.849 \\
\hline $45 X-2$ & 061 & 390.11 & 03.103 \\
\hline $45 X-3$ & 115 & 392.15 & 03.541 \\
\hline $45 X-4$ & 062 & 393.12 & 03.471 \\
\hline $45 X-5$ & 114 & 395.14 & 03.263 \\
\hline
\end{tabular}

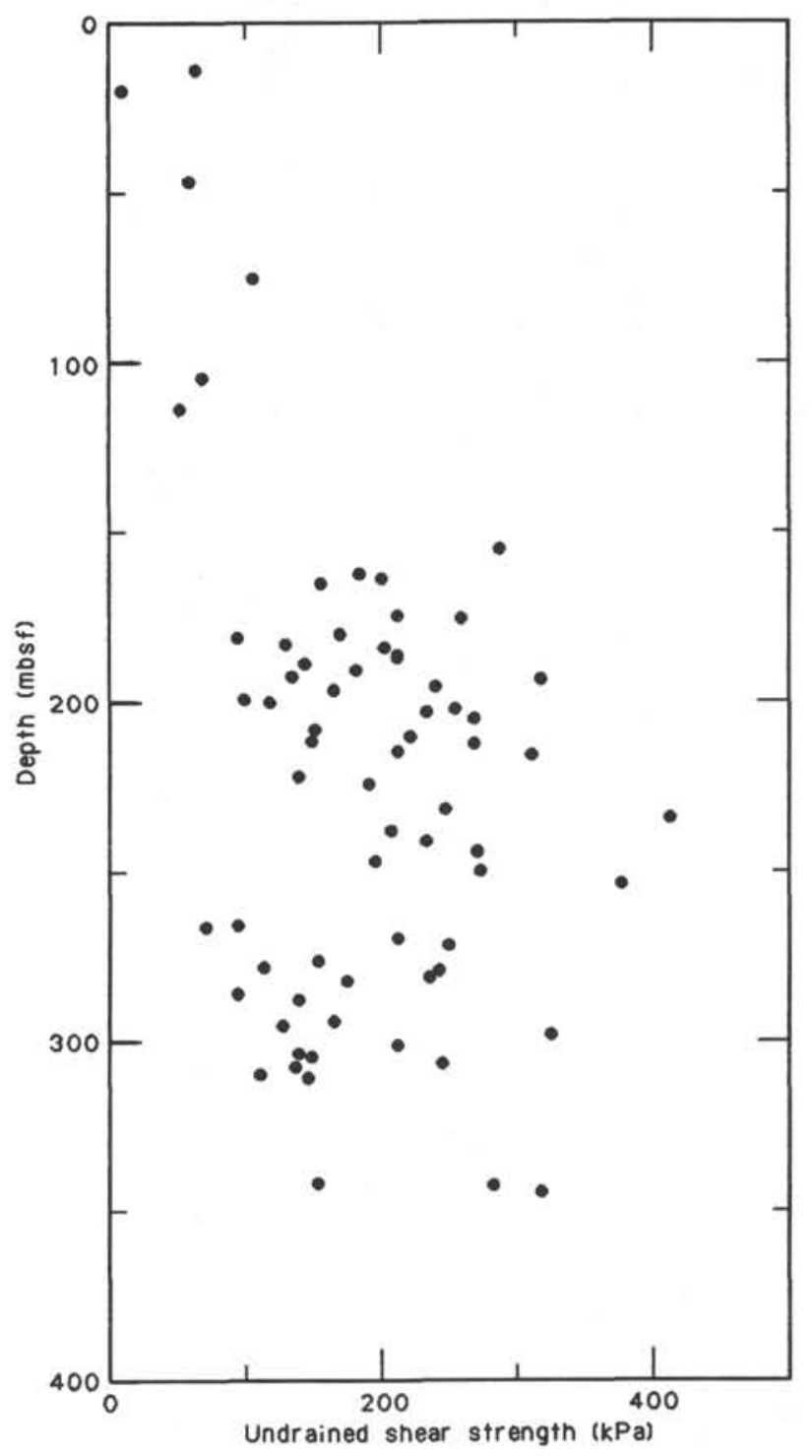

Figure 29. Undrained shear strength vs. depth at Site 717. 
Table 13. Shear-strength measurements from Site 717, Hole C.

\begin{tabular}{|c|c|c|c|c|c|}
\hline \multirow[b]{2}{*}{ Core } & \multirow[b]{2}{*}{ Sect. } & \multicolumn{2}{|c|}{ Int. (cm) } & \multirow{2}{*}{$\begin{array}{l}\text { Depth } \\
\text { (mbsf) }\end{array}$} & \multirow{2}{*}{$\begin{array}{c}\text { Shear } \\
\text { strength } \\
(\mathrm{kPa})\end{array}$} \\
\hline & & top & bot. & & \\
\hline $2 \mathrm{H}$ & 1 & 36 & 38 & 13.86 & 63.8 \\
\hline $2 \mathrm{H}$ & 3 & 53 & 55 & 20.0 & 9.5 \\
\hline $6 x$ & 1 & 77 & 79 & 46.77 & 59.1 \\
\hline $10 \mathrm{X}$ & 1 & 80 & 82 & 75.30 & 106.4 \\
\hline $14 \mathrm{X}$ & 2 & 20 & 22 & 104.70 & 68.6 \\
\hline $15 \mathrm{X}$ & 1 & 131 & 131 & 113.81 & 52.0 \\
\hline $20 \mathrm{X}$ & 4 & 15 & 17 & 155.15 & 288.4 \\
\hline $21 X$ & 2 & 89 & 91 & 162.39 & 184.4 \\
\hline $21 X$ & 3 & 77 & 79 & 163.77 & 201.0 \\
\hline $21 X$ & 4 & 72 & 74 & 165.22 & 156.0 \\
\hline $22 \mathrm{X}$ & 4 & 78 & 80 & 174.78 & 212.8 \\
\hline $22 \mathrm{X}$ & 5 & 11 & 13 & 175.61 & 260.1 \\
\hline $23 \mathrm{X}$ & 1 & 110 & 112 & 180.10 & 170.2 \\
\hline $23 \mathrm{X}$ & 2 & 59 & 61 & 181.09 & 94.6 \\
\hline $23 \mathrm{X}$ & 3 & 105 & 107 & 183.05 & 130.0 \\
\hline $23 \mathrm{X}$ & 4 & 57 & 59 & 184.07 & 203.3 \\
\hline $23 \mathrm{X}$ & 5 & 128 & 130 & 186.28 & 212.8 \\
\hline $23 \mathrm{X}$ & 6 & 57 & 59 & 187.07 & 212.8 \\
\hline $24 \mathrm{X}$ & 1 & 30 & 32 & 188.80 & 144.2 \\
\hline $24 X$ & 2 & 66 & 68 & 190.66 & 182.1 \\
\hline $24 X$ & 3 & 110 & 112 & 192.60 & 134.8 \\
\hline $24 X$ & 4 & 55 & 57 & 193.55 & 319.2 \\
\hline $24 \mathrm{X}$ & 5 & 110 & 112 & 195.60 & 241.2 \\
\hline $24 \mathrm{X}$ & 6 & 55 & 57 & 196.55 & 165.5 \\
\hline $25 \mathrm{X}$ & 1 & 120 & 122 & 199.20 & 99.3 \\
\hline $25 \mathrm{X}$ & 2 & 58 & 60 & 200.08 & 118.2 \\
\hline $25 \mathrm{X}$ & 3 & 110 & 112 & 202.10 & 255.3 \\
\hline $25 \mathrm{X}$ & 4 & 57 & 59 & 203.07 & 234.1 \\
\hline $25 \mathrm{X}$ & 5 & 110 & 112 & 205.10 & 269.5 \\
\hline $26 \mathrm{X}$ & 1 & 65 & 65 & 208.15 & 151.3 \\
\hline $26 \mathrm{X}$ & 2 & 122 & 122 & 210.22 & 222.2 \\
\hline $26 \mathrm{X}$ & 3 & 110 & 112 & 211.60 & 149.0 \\
\hline $26 \mathrm{X}$ & 4 & 42 & 44 & 212.42 & 269.5 \\
\hline $26 \mathrm{X}$ & 5 & 110 & 112 & 214.60 & 212.8 \\
\hline $26 \mathrm{X}$ & 6 & 72 & 74 & 215.72 & 312.1 \\
\hline $27 X$ & 4 & 50 & 52 & 222.00 & 139.5 \\
\hline $27 \mathrm{X}$ & 5 & 120 & 122 & 224.20 & 191.5 \\
\hline $28 \mathrm{X}$ & 4 & 73 & 75 & 231.73 & 248.3 \\
\hline $28 \mathrm{X}$ & 6 & 34 & 36 & 234.34 & 413.8 \\
\hline $29 \mathrm{X}$ & 2 & 60 & 62 & 238.10 & 208.1 \\
\hline $29 X$ & 4 & 68 & 70 & 241.18 & 234.1 \\
\hline $29 X$ & 6 & 71 & 73 & 244.21 & 271.9 \\
\hline $30 \mathrm{X}$ & 1 & 130 & 132 & 246.80 & 196.2 \\
\hline $30 \mathrm{X}$ & 3 & 124 & 126 & 249.74 & 274.3 \\
\hline $30 \mathrm{x}$ & 6 & 59 & 61 & 253.59 & 378.3 \\
\hline $32 \mathrm{X}$ & 1 & 110 & 112 & 265.60 & 94.6 \\
\hline $32 \mathrm{X}$ & 2 & 16 & 18 & 266.16 & 70.9 \\
\hline $32 x$ & 4 & 58 & 60 & 269.58 & 212.8 \\
\hline $32 \mathrm{X}$ & 5 & 108 & 110 & 271.58 & 250.6 \\
\hline $33 \mathrm{X}$ & 2 & 72 & 74 & 276.22 & 153.7 \\
\hline $33 \mathrm{X}$ & 3 & 110 & 112 & 278.10 & 113.5 \\
\hline $33 \mathrm{X}$ & 4 & 57 & 59 & 279.07 & 243.5 \\
\hline $33 x$ & 5 & 110 & 112 & 281.10 & 236.4 \\
\hline $33 \mathrm{X}$ & 6 & 56 & 58 & 282.06 & 175.0 \\
\hline $34 X$ & 2 & 86 & 88 & 285.86 & 94.6 \\
\hline $34 \mathrm{X}$ & 3 & 110 & 112 & 287.60 & 139.5 \\
\hline $35 \mathrm{X}$ & 1 & 110 & 112 & 294.10 & 165.5 \\
\hline $35 \mathrm{X}$ & 2 & 83 & 85 & 295.33 & 127.7 \\
\hline $35 \mathrm{X}$ & 4 & 60 & 62 & 298.10 & 326.3 \\
\hline $35 \mathrm{X}$ & 6 & 69 & 71 & 301.19 & 212.8 \\
\hline $36 \mathrm{X}$ & 1 & 110 & 110 & 303.60 & 139.5 \\
\hline $36 \mathrm{X}$ & 2 & 57 & 59 & 304.57 & 149.0 \\
\hline $36 \mathrm{X}$ & 3 & 110 & 112 & 306.60 & 245.9 \\
\hline $36 \mathrm{X}$ & 4 & 57 & 59 & 307.57 & 137.1 \\
\hline $36 \mathrm{X}$ & 5 & 120 & 122 & 309.70 & 111.1 \\
\hline $36 \mathrm{X}$ & 6 & 70 & 72 & 310.70 & 146.6 \\
\hline $40 \mathrm{X}$ & 1 & 130 & 132 & 341.80 & 153.7 \\
\hline $40 \mathrm{X}$ & 2 & 47 & 49 & 342.47 & 283.7 \\
\hline $40 \mathrm{X}$ & 3 & 95 & 97 & 344.45 & 319.2 \\
\hline
\end{tabular}

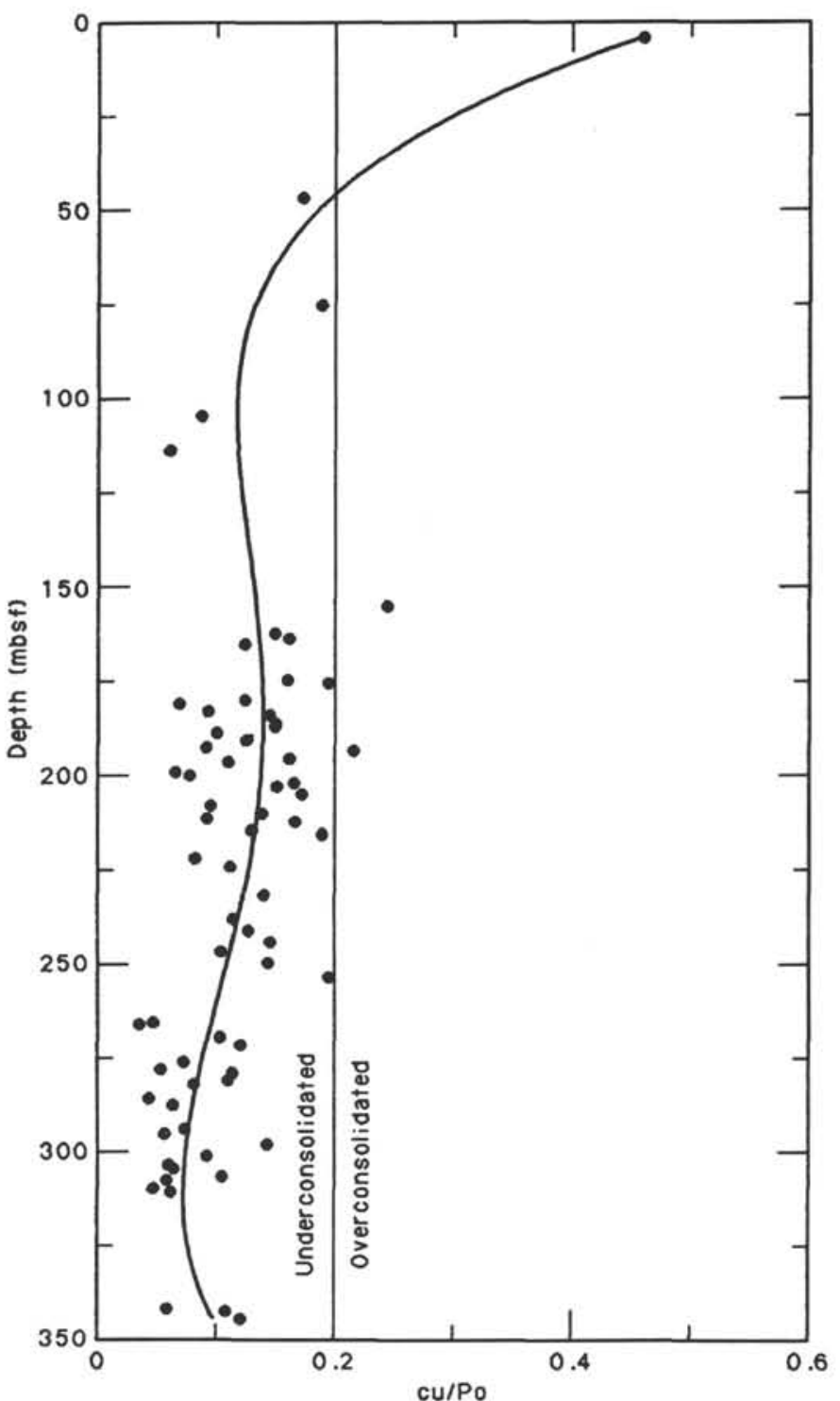

Figure 30. Ratio of undrained shear strength (cu) to effective overburden pressure $\left(P_{o}\right)$ vs. depth at Site 717 . Sediments with a ratio of less than 0.2 are underconsolidated. 

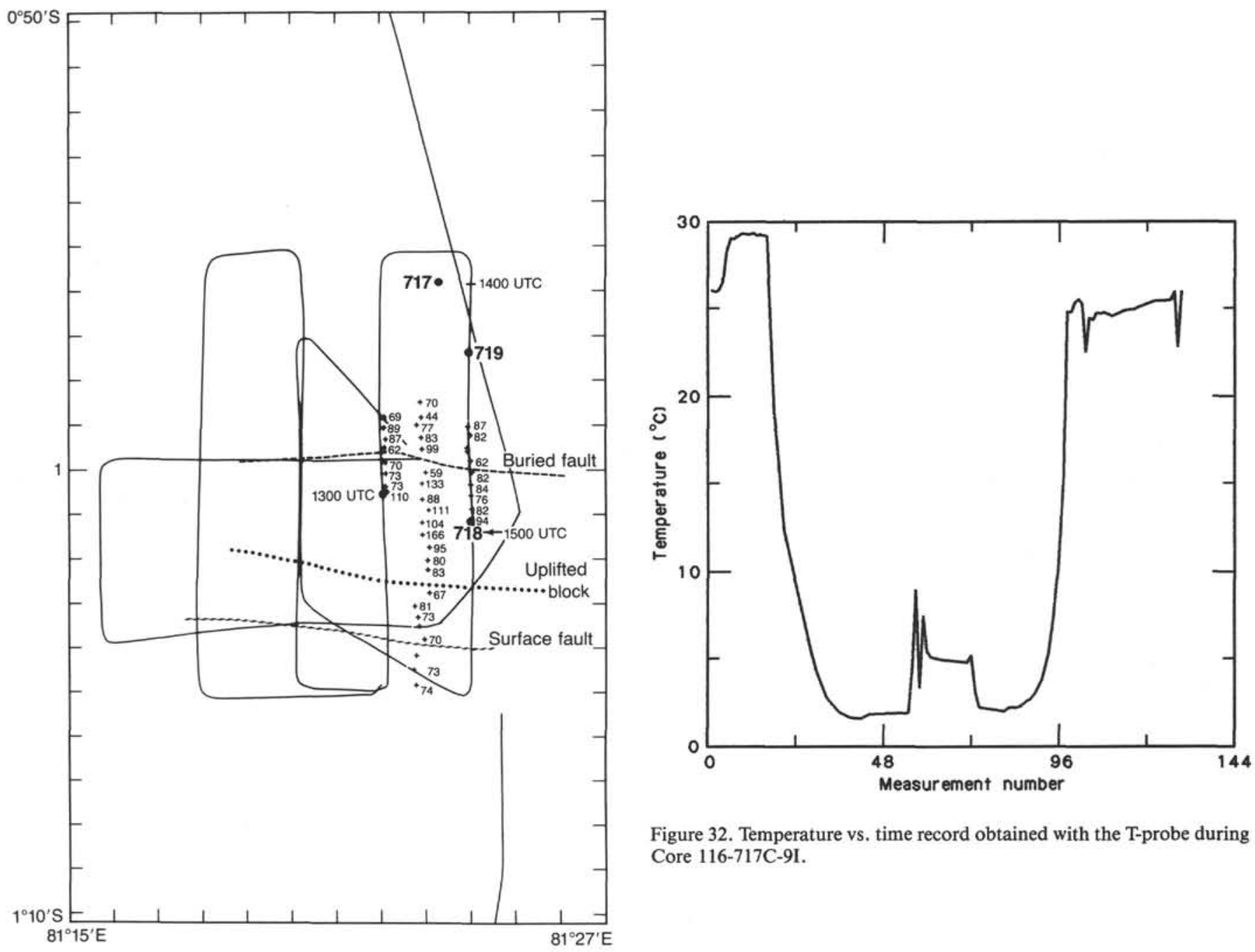

Figure 32. Temperature vs, time record obtained with the T-probe during Core $116-717 \mathrm{C}-9 \mathrm{I}$

Figure 31. Site survey carried out in 1986 on board Robert D. Conrad. Heat-flow stations are shown by small crosses with value in $\mathrm{mW} / \mathrm{m}^{2}$. Locations of Sites are shown by large dots. Also shown are locations of seismic reflection lines (solid lines). 


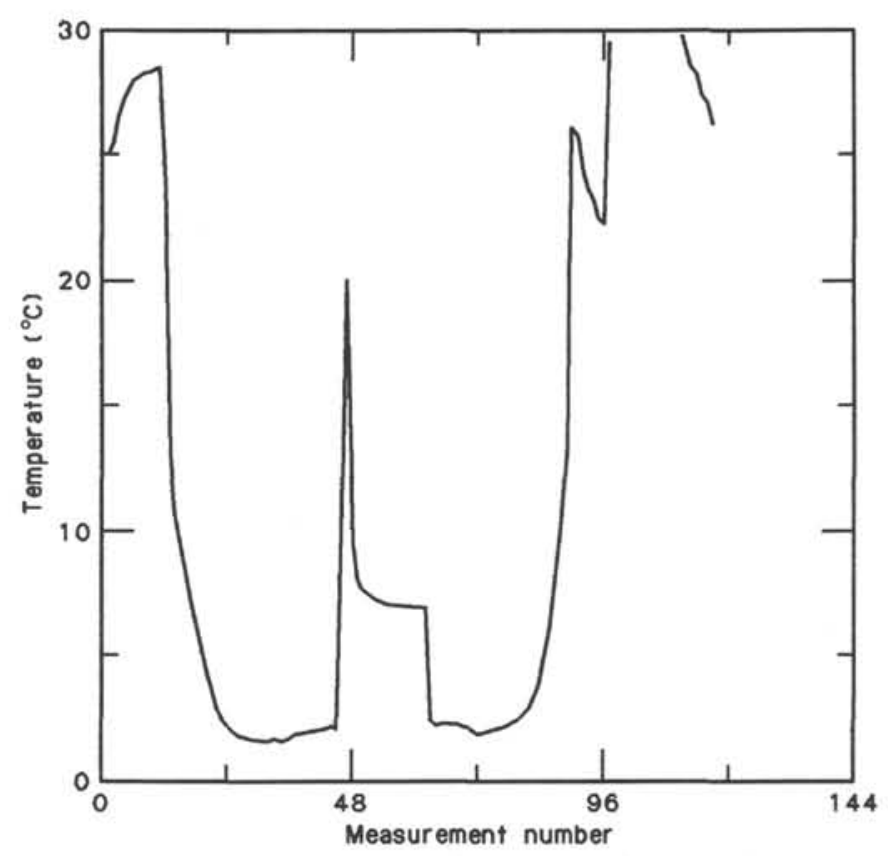

Figure 33. Temperature vs. time record obtained with the T-probe during Core 116-717C-17I.

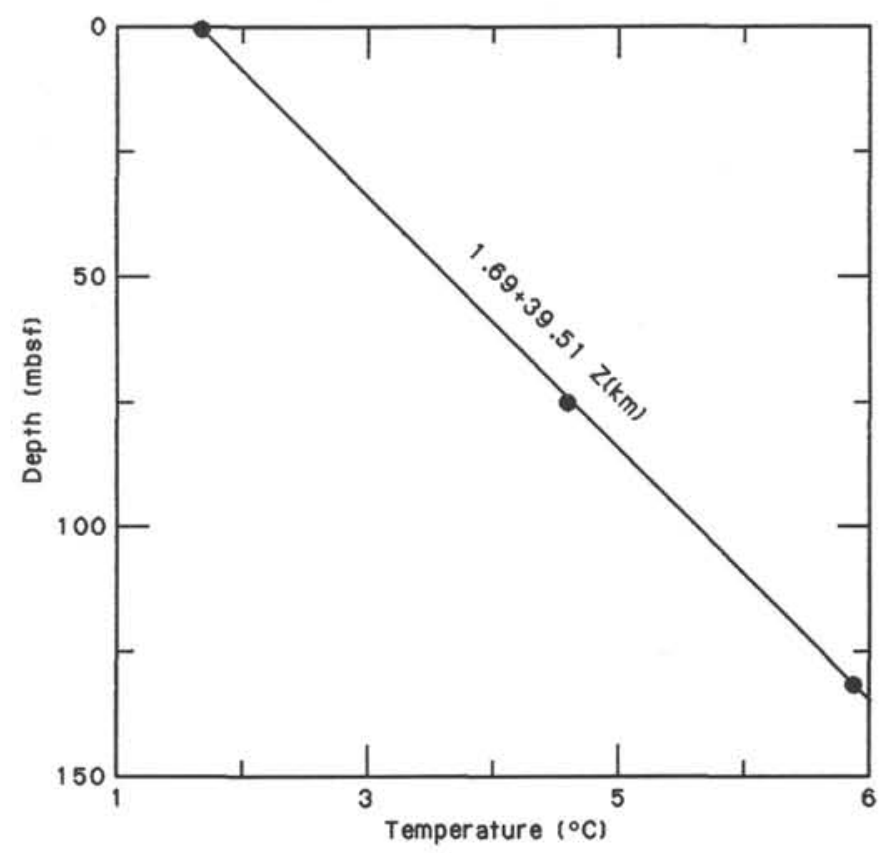

Figure 34. Temperature in Hole $717 \mathrm{C}$ vs. depth. Line is the geothermal gradient determined by a least-squares fit to a straight line. 


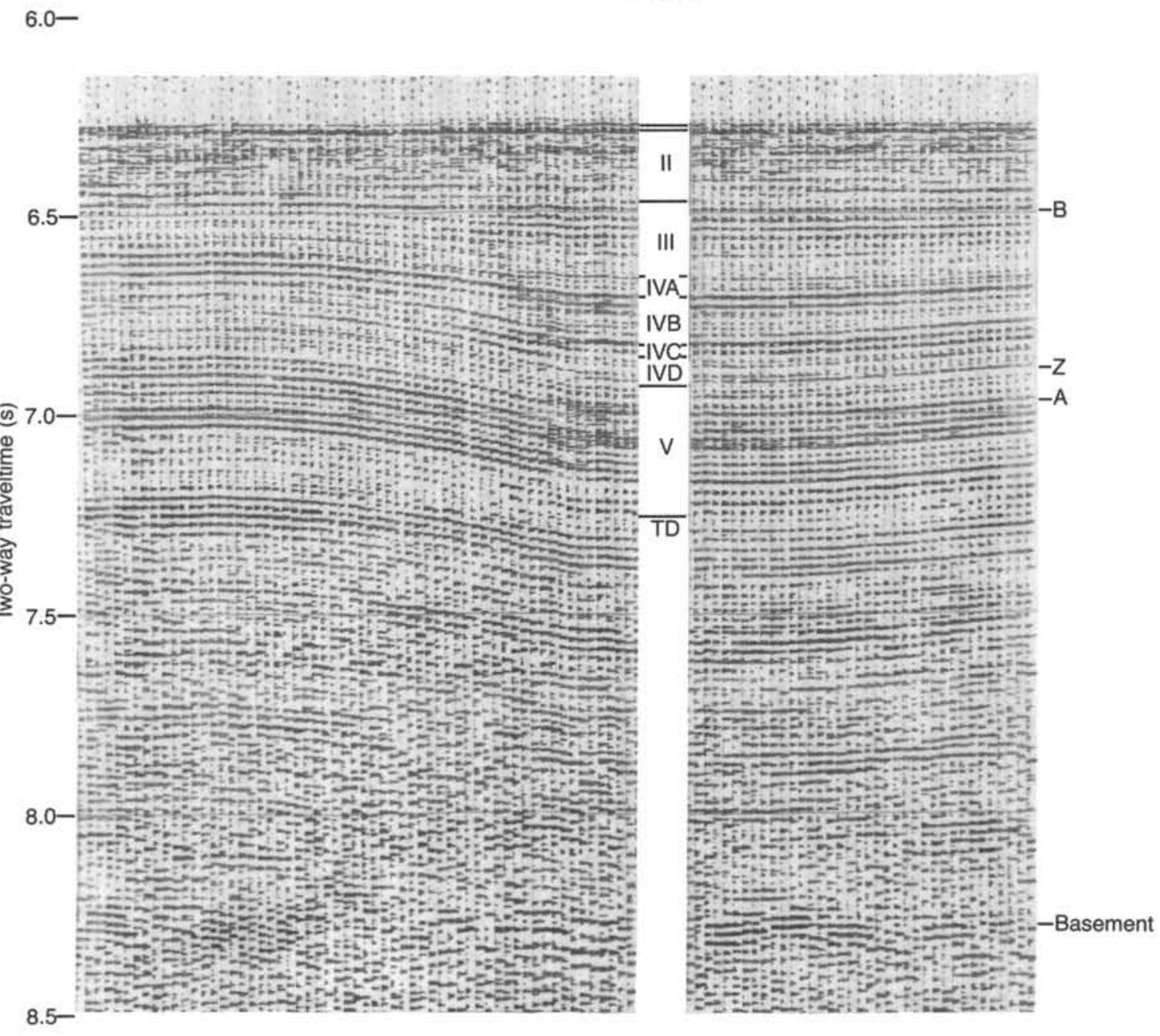

Figure 35. Single-channel seismic reflection line obtained by JOIDES Resolution on the final approach to Site 717. Lithologic units from Hole 717C are shown at Site 717 with depths to lithologic boundaries converted to two-way traveltime. The position of the lithologic boundaries in the seismic section were determined by tracing reflectors from Site 719, where a tie between the cores and the seismic section was obtained from a synthetic seismogram constrained by well-log data. Unconformities " $\mathrm{A}$ " and " $\mathrm{B}$ " and Reflector " $\mathrm{Z}$ " discussed in text are noted to the right of the profile. Total length of the seismic section shown is about $5 \mathrm{~km}$.

NOTE: All core description forms ("barrel sheets") and core photographs have been printed on coated paper and bound as Section 3, near the back of the book, starting on page 213 . 